UNIVERSIDADE ESTADUAL PAULISTA “JÚLIO DE MESQUITA FILHO” FACULDADE DE CIÊNCIAS AGRONÔMICAS CÂMPUS DE BOTUCATU

DOSES DE COMPOSTO ORGÂNICO, COM E SEM FÓSFORO ADICIONADO AO SOLO, NA PRODUÇÃO E QUALIDADE DE SEMENTES DE ALFACE

BÁRBARA RODRIGUES DE QUADROS

Dissertação apresentada à Faculdade de Ciências Agronômicas da Unesp - Câmpus de Botucatu, para obtenção do título de Mestre em Agronomia (Horticultura)

BOTUCATU - SP

(Fevereiro - 2010) 
UNIVERSIDADE ESTADUAL PAULISTA “JÚLIO DE MESQUITA FILHO” FACULDADE DE CIÊNCIAS AGRONÔMICAS CÂMPUS DE BOTUCATU

\section{DOSES DE COMPOSTO ORGÂNICO, COM E SEM FÓSFORO ADICIONADO AO SOLO, NA PRODUÇÃO E QUALIDADE DE SEMENTES DE ALFACE}

\section{BÁRBARA RODRIGUES DE QUADROS}

Orientador: Prof. Dr. Antonio Ismael Inácio Cardoso

Dissertação apresentada à Faculdade de Ciências Agronômicas da Unesp - Câmpus de Botucatu, para obtenção do título de Mestre em Agronomia (Horticultura)

BOTUCATU - SP

(Fevereiro - 2010) 
FICHA CATALOGRÁFICA ELABORADA PELA SEÇÃO TÉCNICA DE AQUISIÇÃO E TRATAMENTO DA INFORMAÇÃO SERVIÇO TÉCNICO DE BIBLIOTECA E DOCUMENTAÇÃO - UNESP - FCA

- LAGEADO - BOTUCATU (SP)

Quadros, Bárbara Rodrigues de, 1984-

Q1d Doses de composto orgânico, com e sem fósforo adicionado ao solo, na produção e qualidade de sementes de alface / Bárbara Rodrigues de Quadros. Botucatu : [s.n.], 2010.

v, 62 f. : tabs., gráfs., fots. color.

Dissertação (Mestrado) - Universidade Estadual Pauli ta, Faculdade de Ciências Agronômicas, Botucatu, 2010

Orientador: Antonio Ismael Inácio Cardoso

Inclui bibliografia.

1. Lactuca sativa. 2. Adubação fosfatada. 3. Adubação orgânica. 4. Germinação. 5. Vigor de sementes. I. Cardoso, Antonio Ismael Inácio. II. Universidade Estadual Paulista "Júlio de Mesquita Filho" (Campus de Botucatu). Faculdade de Ciências Agronômicas. III. Título. 


\section{UNIVERSIDADE ESTADUAL PAULISTA "JULIO DE MESQUITA FILHO" \\ FACULDADE DE CIÊNCIAS AGRONÔMICAS \\ CAMPUS DE BOTUCATU}

\section{CERTIFICADO DE APROVAÇÃO}

TITULO: "DOSES DE COMPOSTO ORGÃNICO, COM E SEM FÓSFORO ADICIONADO AO SOLO, PRODUÇÃo E QUALIDADE DE SEMENTES DE ALFACE".

ALUNA: BÁRBARA RODRIGUES DE QUADROS

ORIENTADOR: PROF. DR. ANTONIO ISMAEL INÁCIO CARDOSO

Aprovado pela Comissão Examinadora

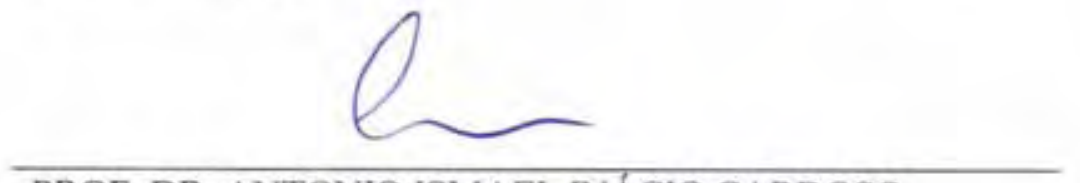

PROF. DR. ANTONIO ISMAEL INÁCIO CARDOSO

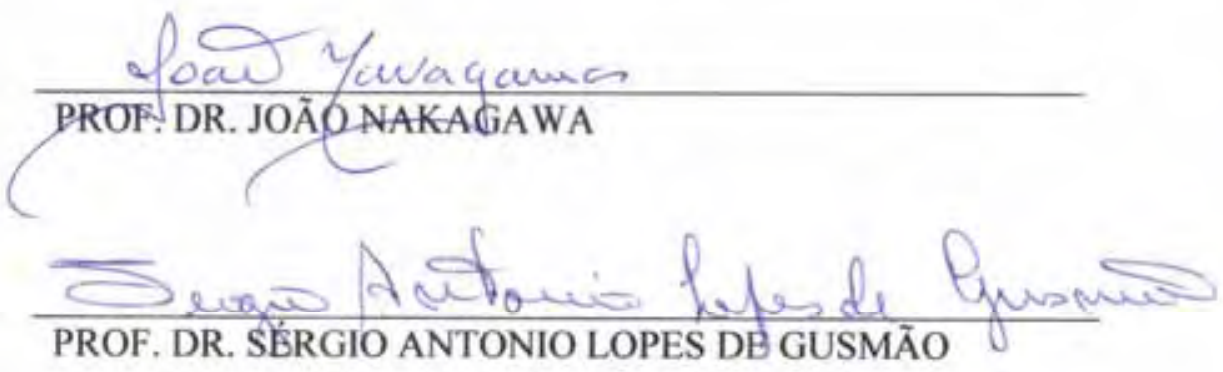

Data da Realização: 05 de Fevereiro de 2010. 


\section{Dedico}

À minha família,

pelo carinho, compreensão e alegrias.

\section{Ofereço}

À minha mãe,

Maria das Graças Rodrigues. 


\section{AGRADECIMENTOS}

A Deus...

A minha família pelo carinho, dedicação, compreensão, apoio e força.

Ao Professor Ismael, pela orientação, paciência, atenção e disponibilidade durante todo o período do curso, os meus sinceros agradecimentos.

Ao Professor Sérgio Antonio Lopes de Gusmão, por se colocar disponível a participar da minha defesa e por ter sido a primeira pessoa a me dar oportunidade durante a minha vida acadêmica.

Aos Professores João Nakagawa, Roberto Lyra Villas Bôas e Simone da Costa Mello por aceitarem participar da minha banca de defesa.

Aos amigos Douglas Seijum, Luciana Pizzani, Rosemary Silva e Valdir Zucareli, os quais considero minha família em Botucatu.

Aos amigos do grupo de oração Divina Misericórdia pelo carinho e caminhada no amor de Deus.

A todos os amigos que fiz em Botucatu, em especial: Aline Fonseca, Anamaria Ramos, Ariane Salatta, Carla Corrêa, Caroline Mateus, Claudiana Moura, Cenira Martins, Cristiane Kano, Didie Martins, Danila Monte, Débora Kestring, Edvar de Sousa, Efrain Santana, Felipe Magro, Humberto Sampaio, Jeferson Klein, Luciana Borges, Manoel Euzébio, Maria Augusta Tremocoldi, Ricardo Lima, Sérgio Marques, Susiane Moura, Simone Ciavatta, Thaise Ribeiro.

À Universidade Estadual Paulista/Faculdade de Ciências Agronômicas, pela oportunidade concedida de realização do curso. 
A todos os funcionários da fazenda São Manuel, Departamento de Horticultura, Seção de PósGraduação e Biblioteca.

À Capes, pela concessão da bolsa de mestrado. 


\section{SUMÁRIO}

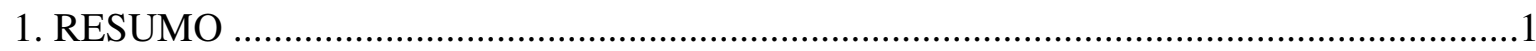

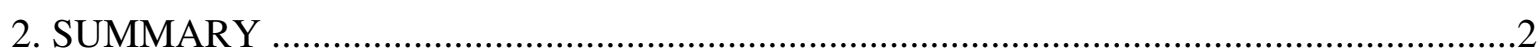

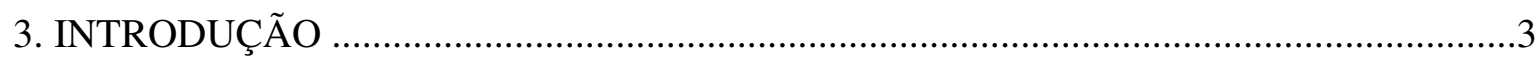

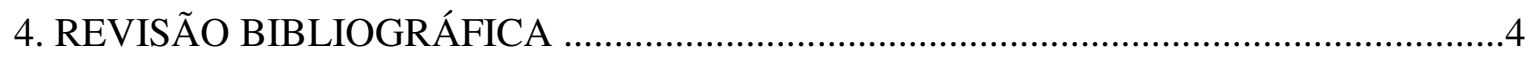

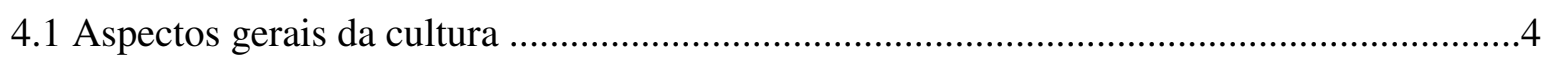

4.2 Nutrição mineral na produção e qualidade de sementes.....................................................5

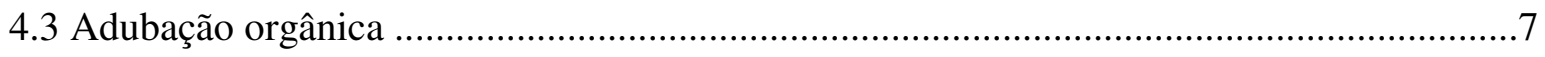

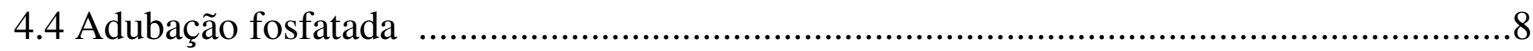

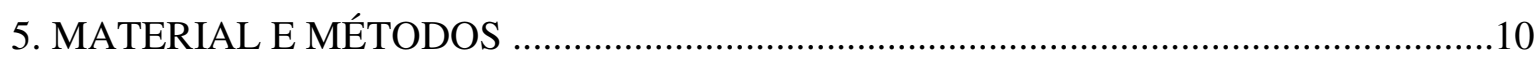

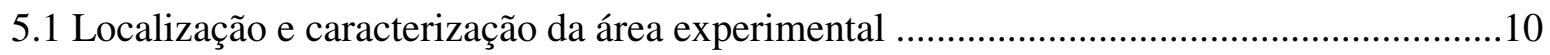

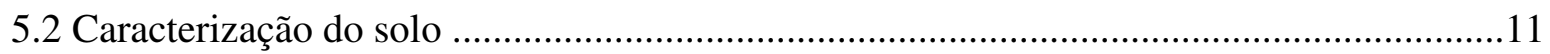

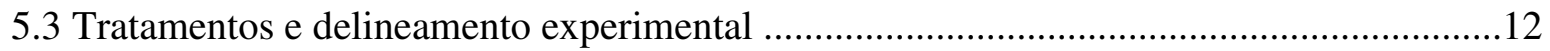

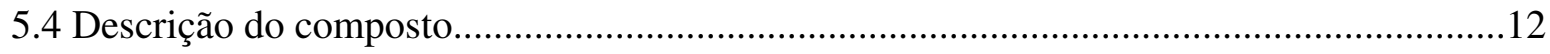

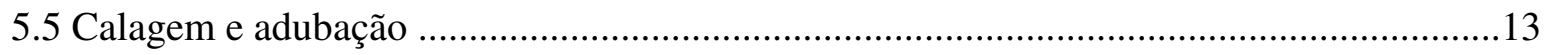

5.6 Cultivar utilizada, obtenção das mudas e condução das plantas.......................................14

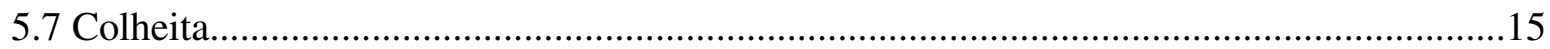

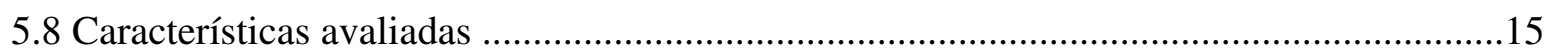

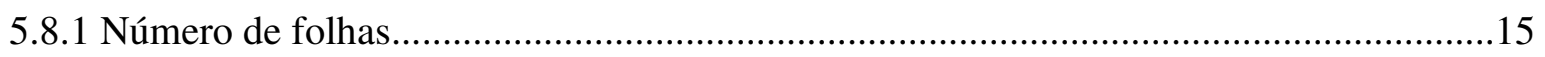

5.8.2 Características vegetativas das plantas no final da colheita ........................................16

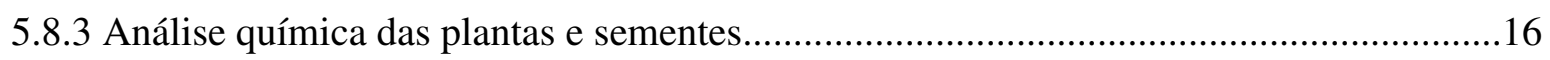

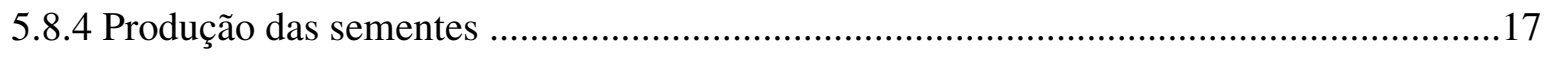

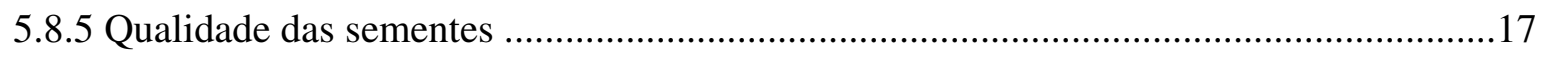

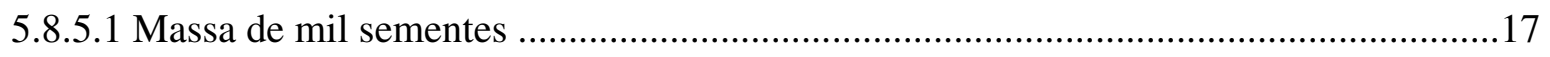

5.8.5.2 Teste de germinação ....................................................................................... 17

5.8.5.3 Primeira contagem de germinação ............................................................................ 17

5.8.5.4 Índice de velocidade de germinação (IVG) ............................................................18

5.8.5.5 Emergência de plântulas em bandeja .........................................................................18

5.8.5.6 Índice de velocidade de emergência de plântulas (IVE) .............................................19 
5.8.5.7 Condutividade elétrica das sementes .20

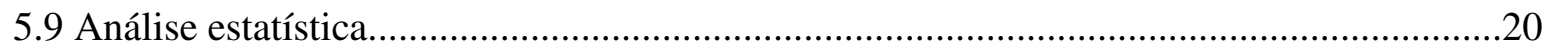

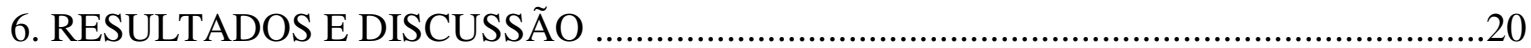

6.1 Temperaturas observadas durante condução do experimento .............................................20

6.2 Análise química do solo coletado um mês após o transplante das mudas de alface ..........21

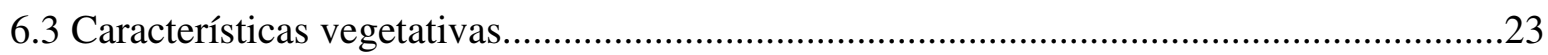

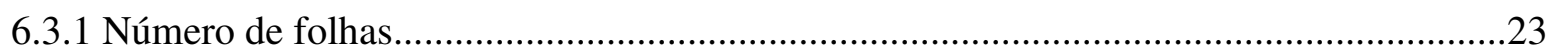

6.3.2 Massa de matéria verde da parte aérea das plantas ao final do ciclo ..............................26

6.3.3 Massa de matéria seca da parte aérea das plantas ao final do ciclo............................... 27

6.4.1Teor de macronutrientes no caule + folhas + hastes florais no final do

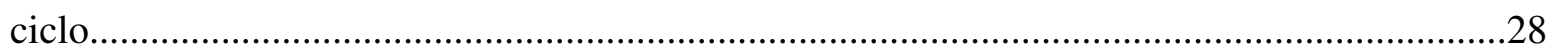

6.4.2 Teor de micronutrientes no caule + folhas + hastes florais no final do ciclo...............31

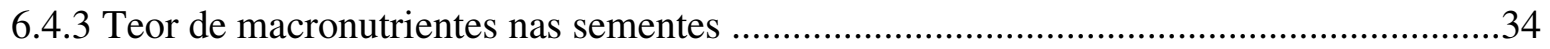

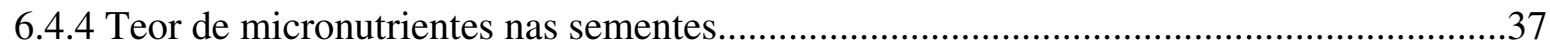

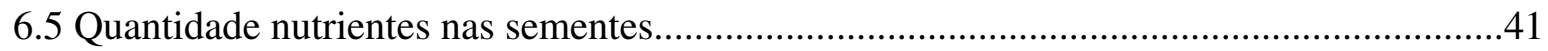

6.5.1 Quantidade de macronutrientes nas sementes................................................................

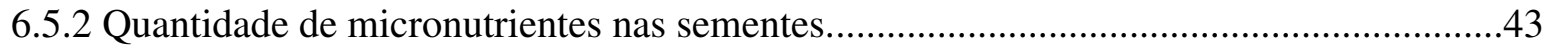

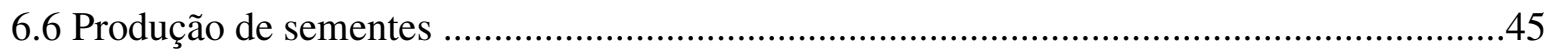

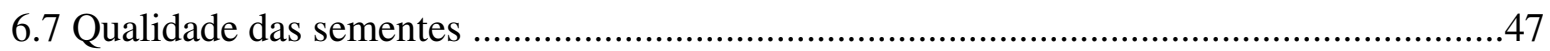

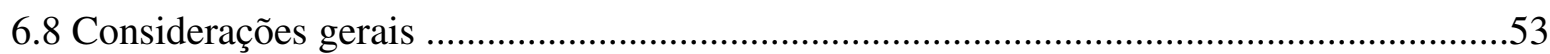

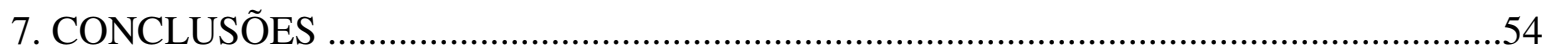

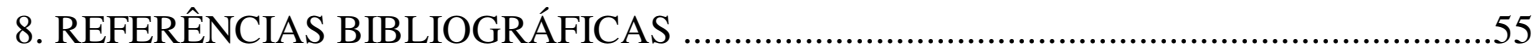




\section{RESUMO}

Devido à escassez de informações relacionadas ao efeito da adubação na produção e qualidade de sementes de hortaliças, nota-se a necessidade de determinar a demanda nutricional e a dose dos nutrientes para auxiliar na recomendação que proporcione a melhor produtividade de sementes de boa qualidade. Este trabalho foi conduzido em vaso na Fazenda Experimental São Manuel - UNESP/FCA, São Manuel/SP, com o objetivo de avaliar a resposta a doses de composto orgânico, com e sem fósforo adicionado ao solo, na produção e qualidade de sementes de alface crespa cultivar Verônica. O delineamento experimental foi em blocos casualizados, com dez tratamentos $\left(0 ; 20 ; 40 ; 60 ; 80 \mathrm{t} \mathrm{ha}^{-1}\right.$ de composto orgânico, com e sem $400 \mathrm{~kg} \mathrm{ha}^{-1} \mathrm{de}$ $\left.\mathrm{P}_{2} 0_{5}\right)$ e quatro repetições. Foram avaliadas características vegetativas das plantas, teor dos nutrientes no caule + folhas + hastes florais, acúmulo e teor de nutrientes nas sementes, produção de sementes (massa e número) por planta e a sua qualidade (germinação e vigor). Os dados foram submetidos às análises de variância e de regressão. A aplicação de fósforo aumentou a produção de sementes. Na presença de fósforo, a dose de 33,4 tha ${ }^{-1}$ de composto orgânico, e na ausência de fósforo, a dose de 49,21 $\mathrm{t} \mathrm{ha}^{-1}$ proporcionaram maior massa de sementes por planta. A qualidade das sementes não foi afetada tanto pela adubação com composto orgânico como com fósforo. A ordem decrescente dos nutrientes acumulados pelas sementes foi: nitrogênio $>$ fósforo $>$ potássio $>$ cálcio $>$ magnésio $>$ enxofre $>$ ferro $>$ manganês $>$ zinco $>$ boro $>$ cobre.

Palavras-chave: Lactuca sativa, adubação fosfatada, adubação orgânica, germinação, vigor de sementes. 


\section{ORGANIC COMPOST LEVELS WITH AND WITHOUT PHOSPHORUS IN LETTUCE SEED YIELD AND QUALITY.}

Botucatu, 2009. 62p. Dissertação (Mestrado em Agronomia/Horticultura) - Faculdade de Ciências Agronômicas, Universidade Estadual Paulista.

Author: BÁRBARA RODRIGUES DE QUADROS

Adviser: Antonio Ismael Inácio Cardoso

\section{SUMMARY}

Due to the scarcity of information regarding the effect of fertilization on yield and quality of vegetable seeds, there is a need to determine nutrient demand and the level of nutrients to support the recommendation that gives the best yield of good quality seeds. This study was conducted out in pots at the Experimental Farm São Manuel - UNESP / FCA, São Manuel / SP, in order to evaluate levels of organic compost, with and without phosphorus added to soil, on yield and quality of lettuce seeds cultivar Veronica. The experimental design was randomized blocks with ten treatments $\left(0,20,40,60,80 \mathrm{t} \mathrm{ha}^{-1}\right.$ of organic compost, with and without $400 \mathrm{~kg} \mathrm{ha}^{-1} \mathrm{P}_{2} \mathrm{O}_{5}$ ) and four replicates. It was evaluated vegetative characteristics of plants, nutrients content in stems + leaf + flower stalks, accumulation and nutrient content in seeds, seed production (weight and number) per plant and quality (germination and vigor). The data were submitted to analysis of variance and regression. Phosphorus application increased seed production. In the presence of phosphorus the level of 33, $4 \mathrm{tha}^{-1}$ of organic compost and in the absence of phosphorus the level of 49,21 $\mathrm{t} \mathrm{ha}^{-1}$ resulted higher seed weight per plant. The quality of seeds was not affected by fertilization with organic compost on with phosphorous. The order of nutrient uptake by seeds was: nitrogen $>$ phosphorus $>$ potassium $>$ calcium $>$ magnesium $>$ Sulfur $>$ iron $>$ manganese $>$ zinc $>$ boron $>$ copper.

Index terms: Lactuca sativa, fertilization, organic fertilization, germination, seed vigor. 


\section{INTRODUÇÃO}

Embora existam estudos sobre nutrição e recomendações de adubação para o cultivo comercial de alface e de outras hortaliças, raramente se encontram trabalhos que abordem os efeitos dos nutrientes na produção e qualidade de sementes. As quantidades de nutrientes utilizadas podem ser diferentes daquelas empregadas para a produção comercial, uma vez que a cultura apresenta um ciclo de desenvolvimento maior, formação de novas estruturas, flores, frutos e sementes, e provavelmente uma extração de nutrientes maior para a produção de sementes.

Apesar de serem em pequeno número, os trabalhos já realizados mostram que a adubação influencia positivamente na produção de sementes, porém, ao se analisar a qualidade das sementes, os resultados na maioria das vezes não são concordantes. Segundo Carvalho \& Nakagawa (2000), uma planta bem nutrida está em condições de produzir mais sementes bem formadas, porém há relatos como o de Delouche (1980), que comenta que as sementes produzidas sob condições marginais, são usualmente tão viáveis e vigorosas quanto aquelas produzidas sob situações mais favoráveis. Nesse caso, a influência da adubação seria basicamente no número de sementes produzidas, não chegando a afetar a qualidade.

Marchesini et al. (1988) relataram que os incrementos de produtividade proporcionados por adubos orgânicos, embora menos imediatos e marcantes do que os obtidos com adubos minerais, apresentam maior duração, provavelmente pela liberação mais progressiva de nutrientes e pelo estímulo do crescimento radicular. Considerando-se que o ciclo da alface para sementes é muito maior que para a produção comercial, pode ser uma alternativa viável a utilização de compostos orgânicos visando suprir a cultura ao longo de todo o ciclo.

Devido à matéria orgânica ser uma grande fonte de nutrientes para a planta, além do papel que esta exerce nas propriedades físicas e biológicas do solo, percebe-se a necessidade do conhecimento da quantidade ideal a ser utilizada para a obtenção de sementes de alta qualidade e com produtividade satisfatória para atender as necessidades do mercado. Ressalta-se, também, o aumento na demanda por sementes produzidas no sistema orgânico, onde não é permitido o uso de adubos químicos solúveis, sendo a matéria orgânica a principal fonte de nutrientes para as plantas neste sistema de produção. 
O fósforo é constituinte de ácidos nucléicos, fosfolipídios, estando envolvido também na regulação da fotossíntese e respiração. Em quantidades adequadas, estimula o desenvolvimento radicular. É essencial para a boa formação de sementes e frutos e seu suprimento adequado, desde o início do desenvolvimento vegetativo, é importante para a formação dos primórdios das partes reprodutivas (MALAVOLTA, 1980; RAIJ, 1991).

O objetivo desse trabalho foi avaliar a influência de doses de composto orgânico, com e sem fósforo adicionado ao solo, na produção e qualidade de sementes de alface.

\section{REVISÃO BIBLIOGRÁFICA}

\subsection{Aspectos gerais da cultura}

A alface originou-se de espécies silvestres que ainda são encontradas em regiões de clima temperado, no sul da Europa e na Ásia Ocidental. Pertence a família Asteraceae e é uma planta anual que floresce sob dias longos e temperaturas elevadas. Dias curtos e temperaturas amenas ou baixas favorecem a etapa vegetativa do ciclo (FILGUEIRA, 2005).

É uma hortaliça folhosa, herbácea, com caule diminuto e não ramificado, ao qual se prendem as folhas que são amplas e crescem em roseta em volta do caule, podendo ser lisas ou crespas, formando ou não uma "cabeça", com coloração em várias tonalidades de verde dentre outras cores. O sistema radicular é muito ramificado e superficial, explorando apenas os primeiros $25 \mathrm{~cm}$ do solo, quando a cultura é transplantada (FILGUEIRA, 2005).

A inflorescência é uma panícula composta de muitos capítulos. Cada capítulo contém vários floretes, normalmente de 12 a 20. O florete apresenta uma única pétala amarela, envolvida por brácteas imbricadas que formam um invólucro, possui cinco estames soldados que formam um tubo. $\mathrm{O}$ estilete é bifurcado no ápice e o ovário contém um único óvulo, com isso, cada florete origina uma única semente que, botanicamente, é um fruto, um aquênio (VIGGIANO, 1990; RYDER, 1998).

Alguns trabalhos demonstram que o florescimento é influenciado tanto pela temperatura, quanto pelo fotoperíodo. Em temperaturas acima de $20^{\circ} \mathrm{C}$, relata-se aumento do estímulo para o pendoamento da alface, aumento da intensidade de desenvolvimento da 
planta, da maturação e da produção de sementes por planta. Torna-se tolerante ao calor após seu florescimento e a temperatura ótima durante o florescimento e o período de maturação das sementes é em torno de $26-30^{\circ} \mathrm{C}$. Dias longos associados a temperaturas elevadas aceleram o ciclo dessa planta (SHINOHARA, 1984; ROUSOS, 1988; VIGGIANO, 1990).

Gray et al. (1988) verificaram que quando as sementes de alface foram produzidas sob condições de altas temperaturas $\left(30 / 20{ }^{\circ} \mathrm{C}\right.$ dia/noite), resultou em menor produção por planta e em sementes menores do que quando cultivada em temperaturas de $25 / 15^{\circ} \mathrm{C}$. Sob condições de temperaturas baixas $\left(20 / 10^{\circ} \mathrm{C}\right)$, a produção foi reduzida, mas as sementes obtidas foram $63 \%$ maiores do que a $25 / 15^{\circ} \mathrm{C}$.

\subsection{Nutrição mineral na produção e qualidade de sementes}

Devido à escassez de informações relacionadas ao efeito da adubação na produção e qualidade de sementes de hortaliças, nota-se a necessidade de determinar a demanda nutricional e a dose dos nutrientes para auxiliar na recomendação de adubação que proporcione a melhor produtividade de sementes de boa qualidade (KANO et al., 2006).

Há relatos de que plantas adubadas de forma adequada e equilibrada apresentam condições de produzir maior quantidade de sementes, aliada à melhor qualidade, por resistirem com mais facilidade às adversidades durante o período de produção. $\mathrm{O}$ aspecto nutricional das plantas afeta o tamanho, a massa e o vigor das sementes, sendo que em muitos casos estes efeitos estão ligados à permeabilidade e integridade das membranas dos tecidos, onde os nutrientes atuam como ativadores enzimáticos ou constituem essas membranas (SÁ, 1994).

De modo geral, a adubação pode influenciar positivamente na produção de sementes, sendo, geralmente, explicado devido ao melhor desenvolvimento das plantas (características vegetativas) proporcionado pela adubação. No entanto, as relações com o potencial fisiológico das sementes não tem sido evidenciadas consistentemente pela pesquisa. Talvez a maior dificuldade para a elucidação desse fato esteja na metodologia adotada pelos pesquisadores e não devido à inexistência de relação entre o estado nutricional da planta ou a fertilidade do solo e o potencial fisiológico das sementes (MARCOS FILHO, 2005). 
Geralmente, quando a pesquisa é conduzida em condições de campo, a tarefa de identificação dos efeitos de nutrientes específicos, sejam macro ou micronutrientes, é severamente prejudicada pela possível interação dos elementos presentes no solo e limitações do controle experimental. A própria dificuldade metodológica para quantificar o(s) elemento(s) estudado(s), devido à variação de procedimentos e de resultados obtidos em análises químicas do solo, é outro fator agravante. Nesse aspecto, os entraves se acentuam quando os micronutrientes representam o principal foco de atenção (MARCOS FILHO, 2005).

As respostas a influência dos nutrientes na qualidade das sementes, quando avaliada, nem sempre são concordantes e, em geral, as explicações na melhora da qualidade, quando discutidas, se resumem devido ao aumento na massa da semente, considerando que, quanto maior o tamanho da semente, mais vigorosa e às próprias funções que cada nutriente exerce na planta, seja estrutural, como constituinte de enzima, seja atuando como ativador enzimático (KANO, 2006).

Outro fato a ser considerado é a possibilidade de as plantas, quando expostas a deficiências nutricionais, apresentarem mecanismo de defesa, também conhecido por "princípio de compensação". Delouche (1980) comenta que as plantas desenvolveram uma extraordinária capacidade de ajustar a produção de sementes aos recursos disponíveis. A resposta típica de plantas à baixa fertilidade do solo ou à falta de água é a redução na quantidade de sementes produzidas e só depois há redução na qualidade. As poucas sementes produzidas sob condições marginais são usualmente tão viáveis e vigorosas como aquelas produzidas sob situações mais favoráveis. Do ponto de vista evolucionário, o ajuste da produção de sementes aos recursos disponíveis tem um alto valor para sobrevivência. As poucas sementes de alta qualidade teriam igual chance de germinar e desenvolver-se em condições adversas. Há também relatos de que o efeito da nutrição das plantas na qualidade da semente possa ser observado só após algum período de armazenamento das sementes (ZUCARELI, 2005).

Kano (2006) e Kano et al. (2006) obtiveram aumento na produção de sementes de alface crespa 'Verônica' com o aumento das doses de potássio e fósforo, respectivamente, ajustando-se ao modelo linear, no entanto, sem influenciar a qualidade das sementes. 


\subsection{Adubação orgânica}

A adubação orgânica tem grande importância no cultivo de hortaliças, principalmente em solos de clima tropical, onde a decomposição de matéria orgânica se realiza intensamente (ALLISON, 1973). Segundo Vidigal et al. (1997), a matéria orgânica melhora as condições químicas, físicas e biológicas do solo, o que reforça o interesse de sua utilização como fonte de nutrientes, principalmente nitrogênio, para a cultura da alface.

Villas Bôas et al. (2004) obtiveram aumentos na massa de matéria fresca e seca de alface e maiores quantidades de macro e micronutrientes com aumentos na quantidade de composto orgânico feito com palhada de feijão. Também Santos et al. (2001) relataram aumentos na produção de alface com maiores quantidades de composto orgânico, assim como aumentos na CTC, teor de fósforo e soma de bases do solo ao final do ciclo da alface, mostrando a importância do efeito residual do composto.

Aumentos lineares de matéria fresca e seca das plantas de alface em cultivos sucessivos foram obtidos por Vidigal et al. (1995a, 1995b) com adição de maiores quantidades de adubos orgânicos. Yuri et al. (2004) testaram diferentes doses de composto orgânico e concluíram que o uso de 56,0 t ha ${ }^{-1}$ aplicado em pré-plantio proporciona maior produção em alface americana. Estudando diferentes quantidades de cama de aviário, Oliveira et al. (2006) obtiveram máxima massa de matéria fresca de alface 'Vera' com a adição de 23 t ha $^{-1}$ do adubo. No geral, a utilização de matéria orgânica tem proporcionado aumento na produção e teor de nutrientes em plantas de alface (VIDIGAL et al., 1995a, 1995b; RODRIGUES E CASALI, 1998; LOPES et al., 2005).

Segundo Villas Boas et al. (2004), grande número de trabalhos encontrados na literatura com a cultura da alface diz respeito ao uso de estercos, resíduos líquidos e restos vegetais, reportando seu efeito como melhoradores do solo e fornecedores de nutrientes. Embora parte dessa informação possa ser extrapolada e assumida como válida no que diz respeito ao uso de compostos, estes têm uma dinâmica no solo diferente dos materiais no estado cru, por ser uma matéria orgânica decomposta e estabilizada (KIEHL, 1985).

Marchesini et al. (1988) relataram que os incrementos de produtividade proporcionados por adubos orgânicos, embora menos imediatos e marcantes do que os obtidos com adubos minerais, apresentam maior duração, provavelmente pela liberação mais progressiva de nutrientes e pelo estímulo do crescimento radicular. Considerando-se que 
o ciclo da alface para produzir sementes é muito maior que para a produção comercial, pode ser uma alternativa viável a utilização de compostos orgânicos visando suprir a cultura ao longo de todo o ciclo.

\subsection{Adubação fosfatada}

O fósforo é fundamental para o sucesso das culturas, devido à baixa disponibilidade na maioria dos solos brasileiros e ao processo de adsorção, tornando-o não disponível. É um elemento absorvido e translocado na planta como $\mathrm{H}_{2} \mathrm{PO}_{4}^{-}$. Tem a função estrutural, sendo constituinte de ácidos nucléicos, fosfolipídios, estando envolvido também na regulação da fotossíntese e respiração. Ele desempenha função essencial no metabolismo energético, fazendo parte das moléculas de ATP, ADP, AMP, GTP, UTP, CTP e pirofosfato (PEREIRA \& FONTES, 2005). Em quantidades adequadas, estimula o desenvolvimento radicular. É essencial para a boa formação de sementes e frutos. Está presente, também, nos processos de transferência de energia e o seu suprimento adequado, desde o início do desenvolvimento vegetativo, é importante para a formação dos primórdios das partes reprodutivas. A deficiência de fósforo geralmente provoca atraso no florescimento e redução no número de sementes e frutos (MALAVOLTA, 1980; RAIJ, 1991).

Para a cultura da alface, embora existam trabalhos que envolvam o efeito do fósforo na produtividade e nas características de crescimento dessa planta, os trabalhos de pesquisas mostram que a quantidade de fósforo recomendada é bastante variada. Filgueira (2005) comenta que, experimentalmente, têm sido obtidas maiores respostas em aumento de produtividade às aplicações de fósforo e de nitrogênio do que de potássio, lembrando da importância do fornecimento de cálcio.

No Estado de São Paulo, Raij et al. (1997) recomendam para produção de alface a quantidade de 400; 300 e $200 \mathrm{~kg} \mathrm{ha}^{-1}$ de $\mathrm{P}_{2} \mathrm{O}_{5}$, quando o teor de $\mathrm{P}_{\text {resina }}$ no solo for de 0 a 25 ; de 26 a 60 e maior que $60 \mathrm{mg} \mathrm{dm}^{-3}$, respectivamente, recomendação semelhante à indicada por Filgueira (2005) que cita a dose de até $400 \mathrm{~kg} \mathrm{ha}^{-1}$ de $\mathrm{P}_{2} \mathrm{O}_{5}$.

Arruda Júnior et al. (2005), em Pernambuco, ao avaliarem a resposta de doses de fósforo aplicadas no solo, com teor de $2 \mathrm{mg} \mathrm{dm}^{-3}$ de $\mathrm{P}_{\text {resina }}$, na produtividade e no teor de fósforo na planta de alface crespa 'Cacheada', obtiveram a maior produção de massa de matéria seca $\left(4,35 \mathrm{~g}\right.$ planta $\left.^{-1}\right)$ e o maior teor desse nutriente $\left(4,6 \mathrm{~g} \mathrm{~kg}^{-1}\right)$ na dose mais alta. 
Bebé et al. (2005) obtiveram, para a cultivar Grand Rapids cultivada no campo, na Bahia, a maior massa de matéria fresca da planta inteira, folha, caule, raiz e área foliar na dose de $300 \mathrm{~kg} \mathrm{ha}^{-1}$ de $\mathrm{P}_{2} \mathrm{O}_{5}$, ao avaliarem doses de $0 ; 150 ; 300$ e $600 \mathrm{~kg} \mathrm{ha}^{-1}$ de $\mathrm{P}_{2} \mathrm{O}_{5}$ , no solo com teor inicial de $16 \mathrm{mg} \mathrm{dm}^{-3}$ de $\mathrm{P}$.

Rodrigues \& Casali (1999), em um estudo sobre adubação orgânica e mineral na alface cultivar Babá de Verão, observaram maior produtividade com o uso da dose equivalente a $495 \mathrm{~kg} \mathrm{ha}^{-1}$ de $\mathrm{P}_{2} \mathrm{O}_{5}$, em um solo com teor inicial de $1 \mathrm{dag} \mathrm{kg}^{-1}$ de $\mathrm{P}_{\text {Mehlich. }}$.

Nicoulaud et al. (1990) obtiveram resposta linear quanto ao rendimento de massa de matéria seca da alface tipo repolhuda lisa ao avaliarem doses de 0 a $120 \mathrm{~kg} \mathrm{ha}^{-1}$ de $\mathrm{P}_{2} \mathrm{O}_{5}$, em um solo com teor inicial de 5,5 $\mathrm{mg} \mathrm{dm}^{-3}$ de $\mathrm{P}_{\text {Mehlich }}$, indicando que essas doses não foram suficientes para se obter o rendimento máximo. Em estudo sobre o efeito de fontes e doses de fósforo $\left(0 ; 300 ; 600\right.$ e $900 \mathrm{~kg} \mathrm{ha}^{-1}$ de $\left.\mathrm{P}_{2} \mathrm{O}_{5}\right)$ na produção de alface americana, Mota et al. (2003) obtiveram maior produtividade total e comercial na dose de 672 e $617 \mathrm{~kg} \mathrm{ha}^{-1}$ de $\mathrm{P}_{2} \mathrm{O}_{5}$, respectivamente, em um solo com teor inicial de $12 \mathrm{mg} \mathrm{dm}^{-3}$ de $\mathrm{P}_{\text {resina. }}$. Sanchez et al. (1989) verificaram resposta na produtividade de alface americana para até 1147 $\mathrm{kg} \mathrm{ha}^{-1}$ de $\mathrm{P}_{2} \mathrm{O}_{5}$.

Experimentos conduzidos na primavera e no inverno nos Estados Unidos, com alface americana, avaliando doses que variaram de 0 a $1376 \mathrm{~kg} \mathrm{ha}^{-1}$ de $\mathrm{P}_{2} \mathrm{O}_{5}$ indicaram produção comercial máxima na dose de $656 \mathrm{~kg} \mathrm{ha}^{-1}$ de $\mathrm{P}_{2} \mathrm{O}_{5}$ na primavera, e $979 \mathrm{~kg}$ ha $^{-1}$ de $\mathrm{P}_{2} \mathrm{O}_{5}$ no inverno (MCPHARLIN et al., 1996; MCPHARLIN \& ROBERTSON, 1997). Já Sanchez \& El-Hout (1995), ao avaliarem a resposta de diversos tipos de alface à adubação fosfatada $\left(0 ; 115 ; 230 ; 460 ; 690 \mathrm{~kg} \mathrm{ha}^{-1} \mathrm{de}_{2} \mathrm{O}_{5}\right.$ em solo com teor de $\mathrm{P}_{\text {water-extractable variando de }}$

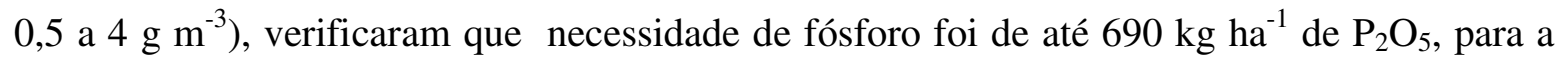
máxima produção.

Nagata et al. (1992) conduziram experimentos no período de 1988 a 1990, também nos Estados Unidos, para avaliarem a resposta de seis cultivares de alface americana à adubação fosfatada, que consistiu de doses que variaram de 0 a $917 \mathrm{~kg} \mathrm{ha}^{-1} \mathrm{de}$ $\mathrm{P}_{2} \mathrm{O}_{5}$, em solo com teor médio de $7,5 \mathrm{mg} \mathrm{dm}^{-3}$ de $\mathrm{P}_{\text {water-extractable. Obtiveram resposta linear para }}$ a maioria das cultivares quanto à produção total e comercial.

Pode-se observar pelos trabalhos citados que, em relação à adubação fosfatada, sem considerar o tipo de alface, e o local do experimento, as respostas são variáveis 
de acordo com o tipo de solo e a disponibilidade desse nutriente no solo. Dos trabalhos apresentados, nenhum teve como objetivo a produção de sementes, portanto, como a extração de nutrientes aumenta com o ciclo, com a formação de novas estruturas, flores, frutos e sementes, é de se esperar resposta a doses mais altas, conforme observado por Kano (2006).

\section{MATERIAL E MÉTODOS}

\subsection{Localização e caracterização da área experimental}

O trabalho foi desenvolvido de janeiro a julho de 2009 na Fazenda Experimental São Manuel, localizada no município de São Manuel - SP, pertencente à Faculdade de Ciências Agronômicas (FCA) da Universidade Estadual Paulista (UNESP), Campus de Botucatu/SP. As coordenadas geográficas da área são: $22^{\circ} 46^{\prime}$ de latitude sul, $48^{\circ}$ 34' de longitude oeste e altitude de 740m.

O clima da região de São Manuel - SP, conforme os critérios adotados por Köppen, baseado nas observações meteorológicas é Cfa (Clima Temperado Mesotérmico). A temperatura média do mês mais quente é $23,8^{\circ} \mathrm{C}$ e a do mês mais frio é de $17,5^{\circ} \mathrm{C}$, com uma temperatura média anual de $21{ }^{\circ} \mathrm{C}$ e total médio de precipitação pluvial anual de 1445 mm (média de 27 anos) (informações obtidas junto ao Departamento de Recursos Naturais Faculdade de Ciências Agronômicas - UNESP).

Os dados de temperatura máxima, média e mínima foram coletados diariamente durante a realização do experimento e obtidos por meio de termômetros de máxima e mínima temperatura do ar, situados dentro das estruturas de cultivo na altura das plantas.

As plantas foram conduzidas em vasos colocados no interior de estruturas de cultivo protegido tipo arco com $20 \mathrm{~m}$ de comprimento, largura de $7 \mathrm{~m}$ e pé direito de $1,8 \mathrm{~m}$, que permaneceram com as laterais abertas.

A extração, limpeza e análises de qualidade das sementes foram realizadas no Departamento de Produção Vegetal - Setor Horticultura, FCA/UNESP, Fazenda Lageado, Botucatu/SP. 


\subsection{Caracterização do solo}

O solo utilizado no experimento foi classificado por Espíndola et al. (1974) como Latossolo Vermelho Escuro fase arenosa, denominado pela nomenclatura do Sistema Brasileiro de Classificação de Solos (EMBRAPA, 1999) como Latossolo Vermelho Distrófico Típico. As principais características químicas do solo, avaliadas de acordo com as metodologias descritas em Raij et al. (2001), encontram-se nas Tabelas 1 e 2. Essas análises foram realizadas no Departamento de Recursos Naturais - Área de Ciência do Solo Faculdade de Ciências Agronômicas.

$\mathrm{O}$ pH foi determinado em solução de $0,01 \mathrm{~mol} \mathrm{~L}^{-1}$ de $\mathrm{CaCl}_{2}$, a matéria orgânica pelo método colorimétrico, o fósforo pelo método da resina trocadora de ânions, o potássio, cálcio e magnésio pelo método da resina trocadora de cátions. A determinação da acidez total $(\mathrm{H}+\mathrm{Al})$ foi através da solução tampão SMP. A determinação de boro foi em água quente e a de cobre, ferro, manganês e zinco foi pelo método da extração com solução de DTPA (dietilenotriamino-pentacético) em pH 7,3.

Tabela 1. Análise química básica do solo utilizado. FCA/UNESP, São Manuel-SP, 2008.

\begin{tabular}{lllllllllll}
\hline $\mathrm{pH}$ & $\mathrm{M} . \mathrm{O}$. & $\mathrm{P}_{\text {resina }}$ & $\mathrm{Al}^{3+}$ & $\mathrm{H}+\mathrm{Al}$ & $\mathrm{K}$ & $\mathrm{Ca}$ & $\mathrm{Mg}$ & $\mathrm{SB}$ & $\mathrm{CTC}$ & $\mathrm{V} \%$ \\
$\mathrm{CaCl}_{2}$ & $\mathrm{~g} / \mathrm{dm}^{3}$ & $\mathrm{mg} / \mathrm{dm}^{3}$ & ---------- & $\mathrm{mmol}_{\mathrm{c}} / \mathrm{dm}^{3}--------$ & & \\
\hline 4,2 & 4 & 3 & --- & 20 & 0,2 & 2 & 1 & 3 & 23 & 12
\end{tabular}

Fonte: Laboratório de análise de solos do Departamento de Recursos Naturais - Área de Ciência do Solo - FCA/UNESP.

Tabela 2. Análise química de micronutrientes do solo utilizado. FCA/UNESP, São ManuelSP, 2008.

\begin{tabular}{ccccc}
\hline BORO & COBRE & FERRO & MANGANÊS & ZINCO \\
\hline 0,34 & 0,5 & 1 & 1,4 & 0,5
\end{tabular}

Fonte: Laboratório de análise de solos do Departamento de Recursos Naturais - Área de Ciência do Solo - FCA/UNESP. 


\subsection{Tratamentos e delineamento experimental}

Foi utilizado o delineamento experimental de blocos casualizados, com dez tratamentos em esquema fatorial $5 \times 2$ (cinco doses de composto orgânico x com e sem adição fósforo) e quatro repetições, com seis plantas por parcela, sendo quatro úteis.

Em razão do maior ciclo e da produção de sementes, que geralmente resulta em maior extração de nutrientes, a maioria das doses utilizadas foi maior que a dose recomendada por Raij et al. (1997) para a produção de alface, que resultaram nos seguintes tratamentos:

T0: tratamento sem composto orgânico; T20: $130 \mathrm{~g} / \mathrm{vaso}$; dose recomendada $\left(20 \mathrm{t} \mathrm{ha}^{-1}\right)$

T40: $260 \mathrm{~g} / \mathrm{vaso}$; o dobro da dose recomendada $\left(40 \mathrm{t} \mathrm{ha}^{-1}\right)$;

T60: $390 \mathrm{~g} / \mathrm{vaso}$; três vezes a dose recomendada $\left(60 \mathrm{t} \mathrm{ha}^{-1}\right)$;

T80: $520 \mathrm{~g} / \mathrm{vaso}$; quatro vezes a dose recomendada $\left(80 \mathrm{t} \mathrm{ha}^{-1}\right)$;

$\mathrm{T} 0+\mathrm{P}$ : tratamento sem composto orgânico $+400 \mathrm{~kg} \mathrm{ha}^{-1}$ de $\mathrm{P}_{2} 0_{5}$;

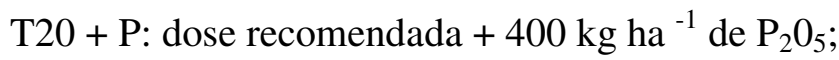

$\mathrm{T} 40+\mathrm{P}:$ o dobro da dose recomendada $+400 \mathrm{~kg} \mathrm{ha}^{-1}$ de $\mathrm{P}_{2} 0_{5}$;

$\mathrm{T} 60+\mathrm{P}$ : três vezes a dose recomendada $+400 \mathrm{~kg} \mathrm{ha}^{-1} \mathrm{de}_{2} \mathrm{O}_{5}$;

$\mathrm{T} 80+\mathrm{P}$ : quatro vezes a dose recomendada $+400 \mathrm{~kg} \mathrm{ha}^{-1} \mathrm{de}_{2} \mathrm{P}_{5}$.

A decisão de se utilizar o fósforo na dose de $400 \mathrm{~kg} \mathrm{ha}^{-1}$ de $\mathrm{P}_{2} 0_{5}$ foi pelo baixo teor deste elemento no solo (Tabela 1) e pelos resultados obtidos por Kano (2006) que relatou a necessidade de grande quantidade de fósforo neste solo para a produção de sementes de alface.

\subsection{Descrição do composto}

Foi utilizado o composto orgânico da marca comercial Biomix ${ }^{\circledR}$, cuja composição inclui cama de frango, farelos, resíduos agroindustriais e cama de cavalo. A análise química do composto encontra-se nas Tabelas 3 e 4, ressaltanto que o lote utilizado no experimento não corresponde ao lote avaliado na análise química, mas ambos pertencem a mesma marca comercial Biomix ${ }^{\circledR}$. 
Tabela 3. Análise química do composto orgânico Biomix ${ }^{\circledR}$. Resultados em \% matéria seca. FCA/UNESP, Botucatu-SP, 2008

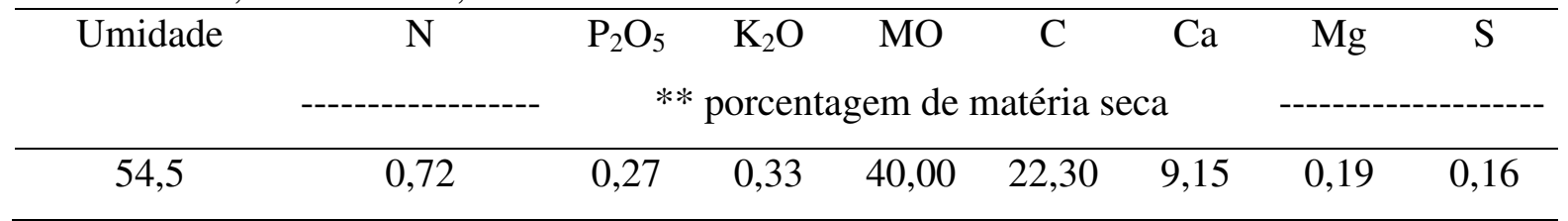

***Teores totais.

Fonte: Laboratório de análise de fertilizantes e corretivos do Departamento de Recursos Naturais - Área de Ciência do Solo - FCA/UNESP.

Tabela 4. Análise química do composto orgânico Biomix ${ }^{\circledR}$. Resultados em mg/kg na matéria seca. FCA/UNESP, Botucatu-SP, 2008.

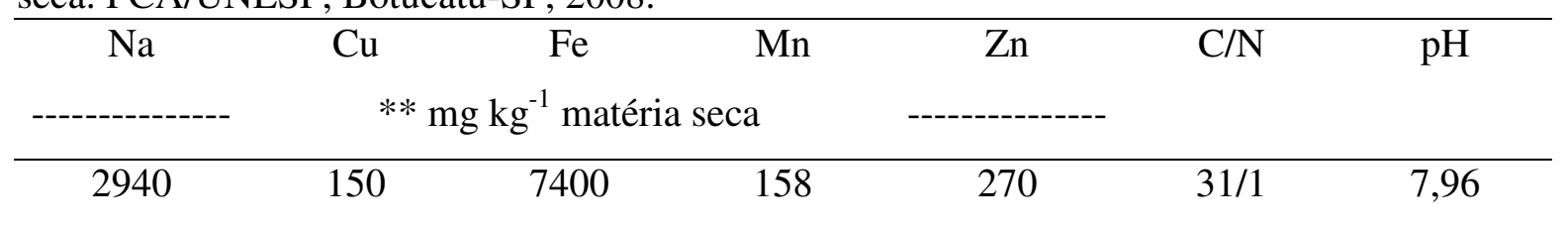

**Teores totais.

Fonte: Laboratório de análise de fertilizantes e corretivos do Departamento de Recursos Naturais - Área de Ciência do Solo - FCA/UNESP.

\subsection{Calagem e adubação}

Com base na análise química do solo, foram realizadas a correção da acidez do solo e adubação de plantio. A calagem foi feita 50 dias antes do transplante das mudas, utilizando-se calcário dolomítico de alta reatividade (PRNT $=95 \%)$, de modo a elevarse a saturação por bases a $80 \%$ e faixa de $\mathrm{pH}$ próximo a 6,0 , conforme recomendação sugerida por Raij et al. (1997).

A adubação de plantio consistiu no fornecimento de 6,5 gramas de superfosfato triplo por vaso para os tratamentos com presença de fósforo, além da adubação orgânica conforme os tratamentos. Não foi feita adubação de plantio e de cobertura com nitrogênio e potássio.

Após a calagem e adubação de plantio, com um mês após o transplante das mudas, foi realizada uma nova análise química do solo para avaliar os teores dos nutrientes promovidos pela adubação. Em cada parcela foram retiradas subamostras de todos os vasos, que depois de misturadas, constituíram uma amostra representativa da parcela. As amostras foram avaliadas de acordo com as metodologias descritas em Raij et al. (2001), conforme descrito no item 5.2. 


\subsection{Cultivar utilizada, obtenção das mudas e condução das plantas}

Foi utilizada a cultivar de alface tipo crespa 'Verônica' (Sakata Seed Sudamerica Ltda.), com plantas de porte grande, folhas de coloração verde claro, alta resistência ao pendoamento precoce e com sementes de coloração preta.

A semeadura foi feita no dia 12 de janeiro de 2009 em bandejas de poliestireno expandido de 128 células contendo substrato comercial para hortaliças colocandose duas a três sementes por célula, com posterior desbaste para uma planta por célula.

As mudas foram transplantadas em vasos de plástico com volume de 13 litros um mês após a semeadura, onde foi conduzida uma planta por vaso. O espaçamento entre linhas de vasos foi de $1,0 \mathrm{~m}$ e os vasos foram distribuídos na linha de modo a proporcionar o espaçamento de $0,5 \mathrm{~m}$ entre plantas (centro a centro dos vasos). Na Figura 1 tem-se uma vista geral do experimento.

O controle fitossanitário foi realizado através de pulverizações com Deltamethrin para controle de pulgão. A irrigação foi realizada durante todo ciclo da cultura, ou seja, até o fim da colheita das sementes, através de gotejadores instalados individualmente nos vasos por um tempo suficiente para proporcionar a formação de uma faixa molhada no solo ao longo da profundidade do vaso. 


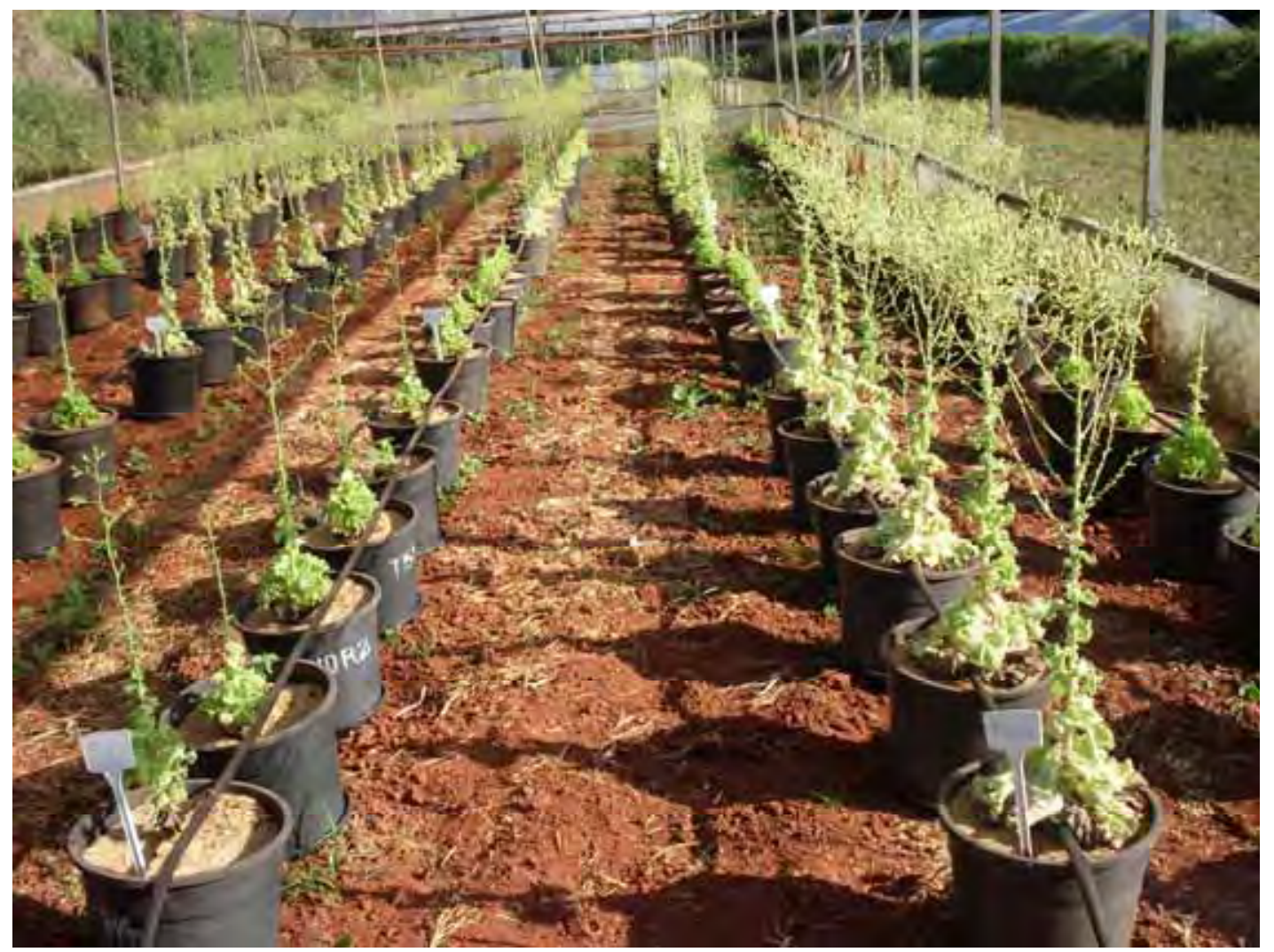

Figura 1. Vista geral do experimento. FCA/UNESP, São Manoel-SP, 2009.

\subsection{Colheita}

A colheita das sementes foi parcela e realizada manualmente na maturidade fisiológica, na fase de "pêlos brancos" ("penugem branca") sobre as inflorescências, conforme Nagai et al. (1995), Reghin et al. (2000) e Kano (2006), inciando aos 64 dias após o transplante nos tratamentos com a presença de fósforo e aos 114 DAT nos tratamentos sem a presença de fósforo e finalizando aos 128 DAT nos tratamentos com a presença de fósforo e aos 147 DAT nos tratamentos sem a presença de fósforo.

\subsection{Características avaliadas}

\subsubsection{Número de folhas}

Foram contadas as folhas de quatro plantas por parcela, obtendo-se a média por planta. As avaliações foram feitas semanalmente a partir do $25^{\circ}$ dia após o transplante. 


\subsubsection{Características vegetativas das plantas no final da colheita}

As avaliações foram realizadas nas plantas coletadas no final da colheita das sementes, com o objetivo de obter algumas medidas de crescimento das plantas de alface para a produção de sementes. Foram elas:

- massa de matéria verde da parte aérea da planta;

- massa de matéria seca da parte aérea da planta (obtida após secagem em estufa de circulação de ar forçada a $65^{\circ} \mathrm{C}$ até atingir massa constante).

\subsubsection{Análise química das plantas e sementes}

Para a obtenção dos teores de nutrientes $(\mathrm{N}, \mathrm{P}, \mathrm{K}, \mathrm{Ca}, \mathrm{Mg}, \mathrm{S}, \mathrm{B}, \mathrm{Cu}$, $\mathrm{Fe}, \mathrm{Mn}$ e $\mathrm{Zn}$ ) na parte aérea das plantas de alface, quatro plantas por parcela foram coletadas após a última colheita das sementes.

Assim que coletadas, as amostras foram levadas ao Laboratório de análise química de plantas do Departamento de Recursos Naturais da UNESP/Botucatu e devidamente lavadas. Após a remoção do excesso de água utilizada na lavagem, as amostras foram colocadas em saco de papel, identificadas e levadas para secagem em estufa de circulação forçada de ar a $65{ }^{\circ} \mathrm{C}$, até atingirem massa constante, conforme Malavolta et al. (1997). Posteriormente, com o uso da balança analítica, foi obtida a massa de material seco de cada planta.

Em seguida, a amostra contendo quatro plantas passou pela moagem no moinho tipo Wiley. A digestão sulfúrica e a digestão por via seca foram utilizadas para a obtenção do extrato visando à determinação de $\mathrm{N}$ e $\mathrm{B}$, respectivamente. A digestão nítricoperclórica foi utilizada para a obtenção dos extratos para as determinações dos demais nutrientes ( $\mathrm{P}, \mathrm{K}, \mathrm{Ca}, \mathrm{Mg}, \mathrm{S}, \mathrm{Cu}, \mathrm{Fe}, \mathrm{Mn}$ e $\mathrm{Zn}$ ), conforme metodologias apresentadas por Malavolta et al. (1997). O mesmo foi feito com uma amostra de sementes de cada parcela.

A partir das análises químicas foram obtidos os teores totais de nitrogênio, fósforo, potássio, cálcio, magnésio e enxofre em $\mathrm{g} \mathrm{kg}^{-1}$ e de boro, cobre, ferro, manganês e zinco em $\mathrm{mg} \mathrm{kg}^{-1}$.

A quantidade dos nutrientes extraídos foi obtida pela multiplicação do teor de cada nutriente pela massa de matéria seca da amostra. 


\subsubsection{Produção das sementes}

As sementes assim que colhidas foram levadas para câmara seca a $40 \%$ de umidade relativa e à temperatura de $20^{\circ} \mathrm{C}$, para melhor conservação até o término da colheita, podendo então iniciar a limpeza manual das mesmas em uma única vez. As sementes foram submetidas à beneficiamento para retirada das chochas e danificadas, através de um aparelho separador de sementes por densidade (modelo 'De Leo Tipo 1', calibrado em uma abertura correspondente a $15 \%$ da área da saída do ar), obtendo-se assim, as sementes classificadas. A calibragem, para a cultura da alface, foi recomendada pela equipe técnica do laboratório de sementes do Departamento de Produção Vegetal, FCA - UNESP, Botucatu. As sementes foram contadas, pesadas (com os resultados expressos em número e massa de sementes por planta) e utilizadas para avaliar a qualidade. Para a obtenção do número total de sementes foi feita amostragem de 1000 sementes obtidas a massa de sementes e com esses valores estimou-se o número de sementes

\subsubsection{Qualidade das sementes}

\subsubsection{Massa de mil sementes}

Foram contadas mil sementes de cada parcela, sendo, em seguida, realizada a determinação da massa ( $\mathrm{g}$ ) em balança com duas casas decimais de precisão.

\subsubsection{Teste de germinação}

O teste padrão de germinação para as sementes foi realizado de acordo com as Regras de Análise de Sementes (BRASIL, 1992), com o uso de caixa gerbox em germinador a $20{ }^{\circ} \mathrm{C}$, sendo analisadas 100 sementes por parcela. A primeira contagem das plântulas normais foi realizada aos quatro dias e a segunda, aos sete dias. As plântulas foram consideradas germinadas ao perceber o aparecimento das folhas cotiledonares.

\subsubsection{Primeira contagem do teste padrão de germinação}

A primeira contagem (quatro dias após a semeadura) das sementes, conforme Brasil (1992), foi considerada como teste de vigorem que as amostras que germinam mais rapidamente, com maior porcentagem de plântulas normais nessa data são consideradas como mais vigorosas (VIEIRA \& CARVALHO, 1994). 


\subsubsection{4. Índice de velocidade de germinação (IVG)}

A obtenção do índice de velocidade de germinação (IVG) foi realizada durante o teste de germinação, com valores de sementes germinadas dia a dia, através da somatória do número de sementes germinadas em cada dia (não cumulativo), dividida pelo número de dias decorridos entre a semeadura e a germinação, conforme Maguire (1962) de acordo com a fórmula: $\mathrm{IVG}=\mathrm{G} 1 / \mathrm{N} 1+\mathrm{G} 2 / \mathrm{N} 2+\ldots+\mathrm{Gn} / \mathrm{Nn}$; onde IVG $=$ índice de velocidade de germinação; G1, G2, Gn = número de sementes germinadas computadas na primeira contagem, na segunda contagem e na última contagem; $\mathrm{N} 1, \mathrm{~N} 2, \mathrm{Nn}=$ número de dias de semeadura à primeira, segunda e última contagem. As avaliações foram diárias e realizadas sempre no mesmo horário até o $7^{\circ}$ dia após a semeadura.

\subsubsection{Emergência de plântulas em bandeja}

O teste foi realizado em bandejas de poliestireno expandido de 128 células contendo substrato comercial Plantmax $\mathrm{HT}^{\circledR}$, conforme metodologia adotada por Lima et al. (2003), adaptada de Vieira \& Carvalho (1994). Foram semeadas superficialmente 100 sementes para cada parcela com duas sementes por célula, as quais foram mantidas em casade-vegetação durante as avaliações. As plântulas foram consideradas emergidas quando as folhas cotiledonares estavam totalmente abertas (Figura 2). Considerou-se o total de sementes emergidas aos sete dias como valor para emergência em bandeja. 


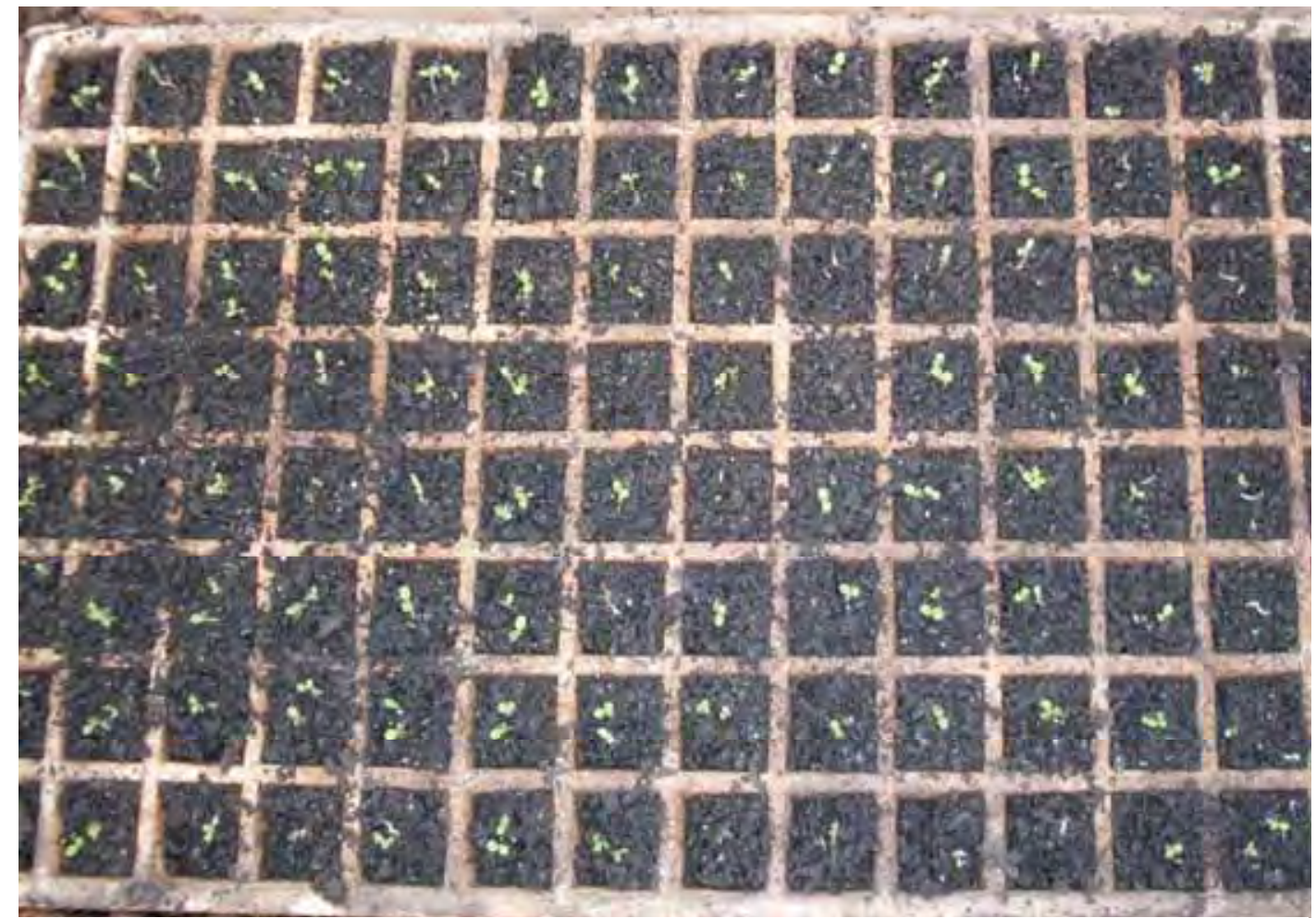

Figura 2. Plântulas de alface durante $o$ teste de emergência em bandeja. FCA/UNESP, Botucatu-SP, 2009.

\subsubsection{6. Índice de velocidade de emergência de plântulas (IVE)}

A obtenção do índice de velocidade de emergência (IVE) foi realizada durante o teste de emergência em bandeja, com valores de plantas emergidas dia a dia, através da somatória do número de plantas emergidas em cada dia (não cumulativo), dividido pelo número de dias decorridos entre a semeadura e a emergência, conforme Maguire (1962) de acordo com a fórmula : IVE $=\mathrm{E} 1 / \mathrm{N} 1+\mathrm{E} 2 / \mathrm{N} 2+\ldots+\mathrm{En} / \mathrm{Nn}$; onde IVE $=$ índice de velocidade de emergência; E1, E2, En = número de plântulas computadas na primeira contagem, na segunda contagem e na última contagem; N1, N2, Nn = número de dias de semeadura à primeira, segunda e última contagem. As avaliações foram diárias e sempre realizadas no mesmo horário até o $7^{\circ}$ dia após a semeadura. 


\subsubsection{Condutividade elétrica das sementes}

Para a determinação da condutividade elétrica foram utilizadas quatro repetições de 50 sementes sem danos, detectados visualmente. Estas foram pesadas em balança analítica de precisão $(0,001 \mathrm{~g})$ e embebidas em $50 \mathrm{~mL}$ de água destilada em copos plásticos descartáveis, mantidos a $20^{\circ} \mathrm{C}$, por 6 horas (FRANZIN et al, 2004). Após a embebição das sementes, fez-se a leitura em condutivímetro, modelo TEC-4MP da Tecnal, e os resultados foram obtidos a partir do valor da condutividade elétrica dividido pela massa úmida das sementes e expressos em $\mu \mathrm{S} / \mathrm{cm} / \mathrm{g}$ sementes.

\subsection{Análise estatística}

Os resultados foram submetidos à análise de variância em esquema fatorial 5x2 (cinco doses de composto orgânico x com e sem fósforo) e foi realizada a análise de regressão para verificar o efeito das doses de composto orgânico separadamente, com e sem fósforo nas características avaliadas.

\section{RESULTADOS E DISCUSSÃO}

\subsection{Temperaturas observadas durante a condução do experimento}

As temperaturas observadas durante o período de condução das plantas dentro das estruturas de cultivo protegido encontram-se na Figura 3.

A cultura da alface floresce sob dias longos e temperaturas elevadas. Dias curtos e temperaturas amenas ou baixas geralmente favorecem a etapa vegetativa do ciclo da maioria das cultivares. A planta resiste, inclusive, a baixas temperaturas e geadas leves. Contrariamente o florescimento, que se inicia com o pendoamento, é favorecido por dias longos e temperaturas elevadas (FILGUEIRA, 2005). Pode-se observar que a temperatura média no período de desenvolvimento vegetativo esteve acima de $20{ }^{\circ} \mathrm{C}$, favorecendo o florescimento da alface, conforme Viggiano (1990). 


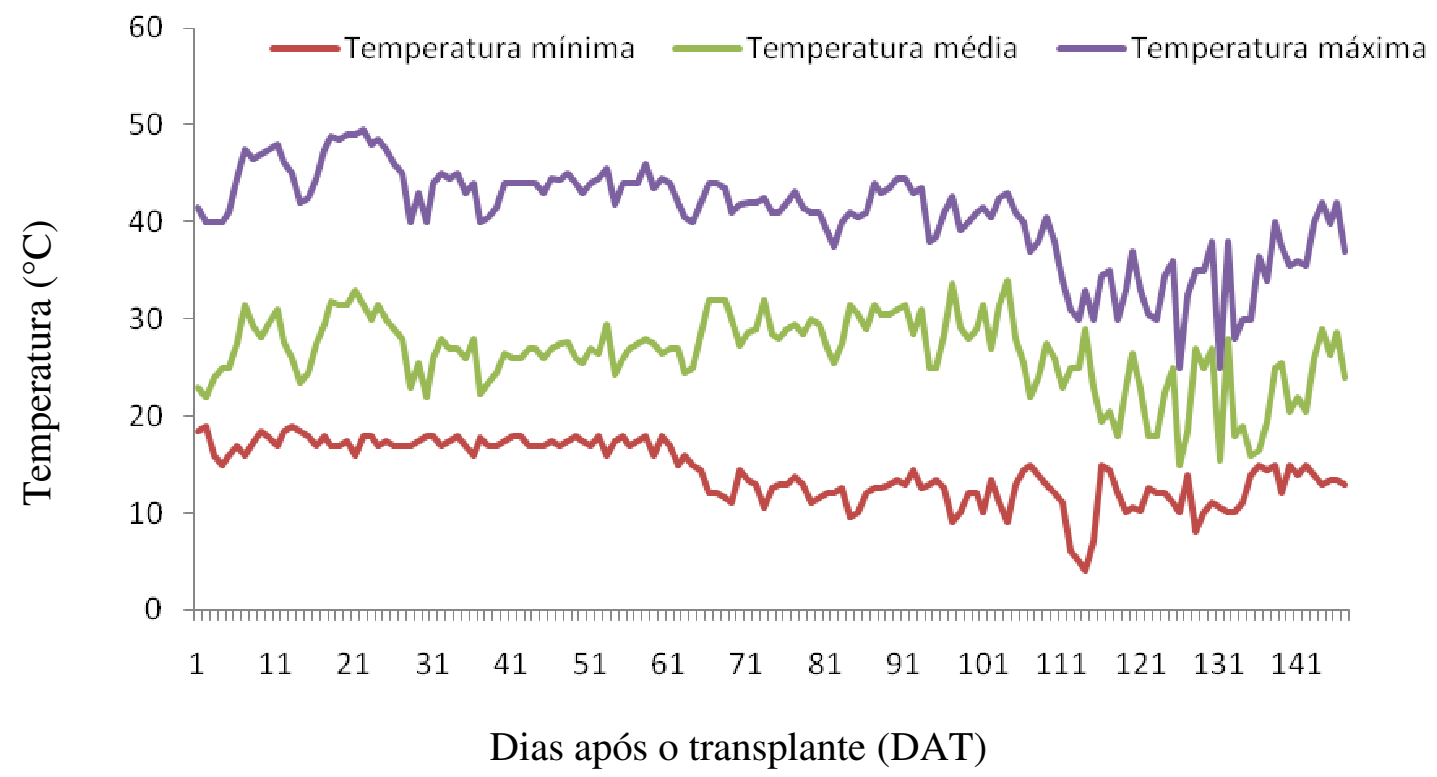

Figura 3. Dados diários de temperaturas máxima, média e mínima durante a condução de plantas de alface para produção de sementes. FCA/UNESP, São Manoel-SP, 2009.

\subsection{Análise química do solo coletado um mês após o transplante das mudas de} alface.

Nas amostras de solo coletadas um mês após o transplante das mudas (Tabelas 5 e 6) verificou-se que os valores de $\mathrm{pH}$ permaneceram superiores a 6,0 indicando uma acidez muito baixa em todos os tratamentos (RAIJ et al., 1997). Os valores de saturação por bases foram altos e em todos os tratamentos estiveram próximos ao recomendado para o cultivo de alface (80\%). Os teores de potássio apresentaram maiores valores com a aplicação de composto orgânico quando comparado a dose $0 \mathrm{t} \mathrm{ha}^{-1} \mathrm{e}$ também foram maiores com a presença de fósforo em relação a ausência. Os teores de potássio variaram de muito baixos a médios, os de magnésio foram médios e os de cálcio foram considerados altos. Quanto aos teores de fósforo, os tratamentos de composto orgânico sem fósforo apresentaram teor muito baixo, semelhante a análise de solo inicial (Tabela 1). Já os tratamentos de composto orgânico com fósforo apresentaram teor médio. A matéria orgânica apresentou valores muito próximos $\left(4,5\right.$ e $\left.6 \mathrm{~g} / \mathrm{dm}^{3}\right)$ para todos os tratamentos, ou seja, mesmo na maior dose $\left(80 \mathrm{t} \mathrm{ha}^{-1} \mathrm{de}\right.$ composto orgânico), seu teor não foi aumentado em relação aos demais e além disso, foi semelhante a análise de solo incial. Quanto aos micronutrientes (Tabela 6), os teores de boro, 
manganês e zinco foram baixos, os de cobre foram médios e os de ferro variaram de baixos a médios. Comparativamente com a análise química do solo inicial observou-se aumento para ferro, diminuição para boro e manganês e semelhantes para cobre e zinco.

Tabela 5. Análise química de macronutrientes presentes no solo um mês após o transplante das mudas de alface. FCA/UNESP, São Manuel-SP, 2009.

\begin{tabular}{lcccccccccc}
\hline Tratamentos & $\begin{array}{c}\mathrm{pH} \\
\left(\mathrm{CaCl}_{2}\right)\end{array}$ & $\begin{array}{c}\mathrm{M} . \mathrm{O} \\
\left(\mathrm{g} / \mathrm{dm}^{3}\right)\end{array}$ & $\begin{array}{c}\mathrm{P}_{\text {resina }} \\
\left(\mathrm{mg} / \mathrm{dm}^{3}\right)\end{array}$ & $\begin{array}{c}\mathrm{H}+\mathrm{Al} \\
-------------\mathrm{mmol}_{\mathrm{c}} / \mathrm{dm}^{3}-----------\end{array}$ & $\mathrm{K}$ & $\mathrm{Ca}$ & $\mathrm{Mg}$ & $\mathrm{SB}$ & $\mathrm{CTC}$ & $\mathrm{V} \%$ \\
\hline T0 & 6,1 & 4 & 3 & 12 & 0,5 & 12 & 5 & 21 & 31 & 76 \\
T20 & 6,2 & 6 & 3 & 12 & 0,9 & 17 & 6 & 24 & 36 & 77 \\
T40 & 6,1 & 6 & 3 & 12 & 0,8 & 14 & 6 & 21 & 33 & 73 \\
T60 & 6,2 & 6 & 3 & 12 & 1,0 & 15 & 6 & 22 & 34 & 75 \\
T80 & 6,2 & 6 & 3 & 11 & 1,1 & 19 & 7 & 28 & 39 & 71 \\
T0+P & 6,2 & 4 & 39 & 12 & 0,9 & 15 & 6 & 22 & 35 & 74 \\
T20+P & 6,4 & 5 & 42 & 12 & 1,6 & 15 & 5 & 22 & 37 & 73 \\
T40+P & 6,5 & 6 & 44 & 11 & 1,6 & 19 & 6 & 31 & 42 & 75 \\
T60+P & 6,2 & 6 & 39 & 12 & 1,7 & 18 & 6 & 28 & 42 & 76 \\
T80+P & 6,4 & 6 & 40 & 12 & 1,6 & 18 & 5 & 23 & 37 & 72 \\
\hline
\end{tabular}

Tabela 6. Análise química de micronutrientes presentes no solo um mês após o transplante das mudas de alface. FCA/UNESP, São Manuel-SP, 2009.

\begin{tabular}{|c|c|c|c|c|c|}
\hline \multirow[t]{2}{*}{ Tratamentos } & BORO & COBRE & FERRO & MANGANÊS & ZINCO \\
\hline & \multicolumn{5}{|c|}{---------------------------------mg/dm³ } \\
\hline T0 & 0,12 & 0,3 & 4 & 0,3 & 0,1 \\
\hline $\mathrm{T} 20$ & 0,12 & 0,3 & 4 & 0,2 & 0,3 \\
\hline $\mathrm{T} 40$ & 0,09 & 0,3 & 4 & 0,2 & 0,2 \\
\hline T60 & 0,11 & 0,3 & 5 & 0,4 & 0,3 \\
\hline T80 & 0,07 & 0,3 & 5 & 0,2 & 0,4 \\
\hline $\mathrm{T} 0+\mathrm{P}$ & 0,08 & 0,3 & 5 & 0,5 & 0,2 \\
\hline $\mathrm{T} 20+\mathrm{P}$ & 0,09 & 0,3 & 7 & 0,3 & 0,2 \\
\hline $\mathrm{T} 40+\mathrm{P}$ & 0,13 & 0,3 & 7 & 0,2 & 0,4 \\
\hline $\mathrm{T} 60+\mathrm{P}$ & 0,06 & 0,3 & 7 & 0,5 & 0,2 \\
\hline $\mathrm{T} 80+\mathrm{P}$ & 0,06 & 0,3 & 7 & 0,3 & 0,2 \\
\hline
\end{tabular}




\subsection{Caracteristicas vegetativas}

\subsubsection{Número de folhas}

Não houve interação significativa entre os fatores estudados (composto orgânico e fósforo). O número de folhas da alface foi maior nos tratamentos com fósforo em todas as semanas avaliadas após o transplante (Tabela 7). Na ausência de fósforo o aumento no número de folhas foi muito pequeno passando de 3,77 aos 25 DAT para 8,09 aos 67 DAT. Já na presença de fósforo o aumento no número de folhas foi numericamente muito maior, passando de 5,34 aos 25 DAT para 32,62 aos 67 DAT. Biscaro et al. (2006) ao avaliarem a cultivar 'Verônica' sob doses de fósforo concluíram que a adubação com uso de fósforo proporciona aumento no número de folhas. Estes autores obtiveram 5,11 folhas na dose máxima estimada de $216,36 \mathrm{~kg} \mathrm{ha}^{-1}$ de $\mathrm{P}_{2} \mathrm{O}_{5}$ aos 20 dias após o transplantio das mudas, valor semelhante ao observado neste experimento nos tratamentos com aplicação de fósforo aos 25 DAT. Silva et al.(2006) também observaram aumento do número de folhas da alface 'Júlia' com o aumento da dose de fósforo.

O número de folhas determinado semanalmente somente apresentou diferença entre as doses de composto orgânico nas avaliações realizadas aos 39 e 53 dias após o transplante (DAT) (Figuras 4 e 5), enquanto nas avaliações realizadas aos 25, 32, 46, 60 e 67 DAT não apresentaram diferenças (Tabela 8).

Tabela 7. Média do número de folhas, obtidos a cada sete dias a partir do $25^{\circ}$ dia após o transplante (DAT) das mudas nos tratamentos com e sem aplicação de fósforo. FCA/UNESP, São Manuel-SP, 2009.

\begin{tabular}{lccccccc}
\hline $\begin{array}{l}\text { Tratamento } \\
\left(\mathrm{kg} \mathrm{ha}^{-1} \mathrm{P}_{2} \mathrm{O}_{5}\right)\end{array}$ & 25 DAT & 32 DAT & 39 DAT & $46 \mathrm{DAT}$ & $53 \mathrm{DAT}$ & 60DAT & 67DAT \\
\hline Com fósforo & $5,34 \mathrm{a}$ & $7,47 \mathrm{a}$ & $10,83 \mathrm{a}$ & $14,71 \mathrm{a}$ & $19,83 \mathrm{a}$ & $29,58 \mathrm{a}$ & $32,62 \mathrm{a}$ \\
Sem fósforo & $3,77 \mathrm{~b}$ & $4,12 \mathrm{~b}$ & $5,09 \mathrm{~b}$ & $5,40 \mathrm{~b}$ & $6,06 \mathrm{~b}$ & $7,52 \mathrm{~b}$ & $8,09 \mathrm{~b}$ \\
\hline $\mathrm{CV}(\%)$ & 13,41 & 9,11 & 10,13 & 9,54 & 8,47 & 10,19 & 9,71 \\
\hline
\end{tabular}

Médias seguidas por mesma letra, nas colunas, não diferem entre si pelo teste $\mathrm{F}$ a $5 \%$ de probabilidade. 
Tabela 8. Média do número de folhas, obtidos a cada sete dias a partir do $25^{\circ}$ dia após o transplante (DAT) das mudas em função de doses de composto orgânico. FCA/UNESP, São Manuel-SP, 2009.

\begin{tabular}{lccccccc}
\hline Tratamento & & & & & & & \\
(t ha ${ }^{-1}$ de composto) & 25 DAT & 32 DAT & 39 DAT* & 46 DAT & $53 \mathrm{DAT}^{*}$ & 60DAT & 67DAT \\
\hline T0 & $4,92 \mathrm{a}$ & $5,71 \mathrm{a}$ & 7,83 & $10,19 \mathrm{a}$ & 12,73 & $18,96 \mathrm{a}$ & $21,09 \mathrm{a}$ \\
T20 & $4,38 \mathrm{a}$ & $5,77 \mathrm{a}$ & 8,65 & $10,35 \mathrm{a}$ & 13,96 & $19,63 \mathrm{a}$ & $20,75 \mathrm{a}$ \\
T40 & $4,45 \mathrm{a}$ & $5,70 \mathrm{a}$ & 7,98 & $10,17 \mathrm{a}$ & 12,79 & $18,71 \mathrm{a}$ & $20,56 \mathrm{a}$ \\
T60 & $4,59 \mathrm{a}$ & $5,81 \mathrm{a}$ & 7,92 & $9,75 \mathrm{a}$ & 12,96 & $18,20 \mathrm{a}$ & $20,23 \mathrm{a}$ \\
T80 & $4,46 \mathrm{a}$ & $5,98 \mathrm{a}$ & 7,44 & $9,81 \mathrm{a}$ & 12,29 & $17,25 \mathrm{a}$ & $19,15 \mathrm{a}$ \\
\hline CV $(\%)$ & 13,41 & 9,11 & 10,13 & 9,54 & 8,47 & 10,19 & 9,71 \\
\hline
\end{tabular}

Médias seguidas por mesma letra, nas colunas, não diferem entre si pelo teste de Tukey a $5 \%$ de probabilidade; $*$ = significativo pelo teste $\mathrm{F}$ a $5 \%$ de probabilidade.

As médias de número de folhas das plantas aos 39 DAT para os tratamentos de composto orgânico com aplicação de fósforo se ajustaram ao modelo de regressão de terceiro grau, destacando-se melhor efeito da dose de $20 \mathrm{t} \mathrm{ha}^{-1}$. Para as doses de composto orgânico sem fósforo não observou-se diferença entre os tratamentos, com média de 5,33 folhas por planta, confirmando o efeito limitante da ausência de fósforo para o desenvolvimento da cultura (Figura 4). As diferenças observadas no número de folhas aos 39 DAT coincidem com o período de máxima demanda de nutrientes pela planta de alface (GARCIA et al. 1982), que ocorre nas últimas semanas do ciclo para a produção visando o mercado "in natura".

Não se observou diferença no número de folhas das plantas aos 53 DAT nas doses de composto orgânico quando se aplicou fósforo no plantio, com média de 21,71 folhas. Já na ausência de fósforo, as doses de composto orgânico se ajustaram ao modelo quadrático de regressão, com número máximo de folhas de 6,36 com a dose estimada de 37,20 t ha ${ }^{-1}$ de composto orgânico (Figura 5). 


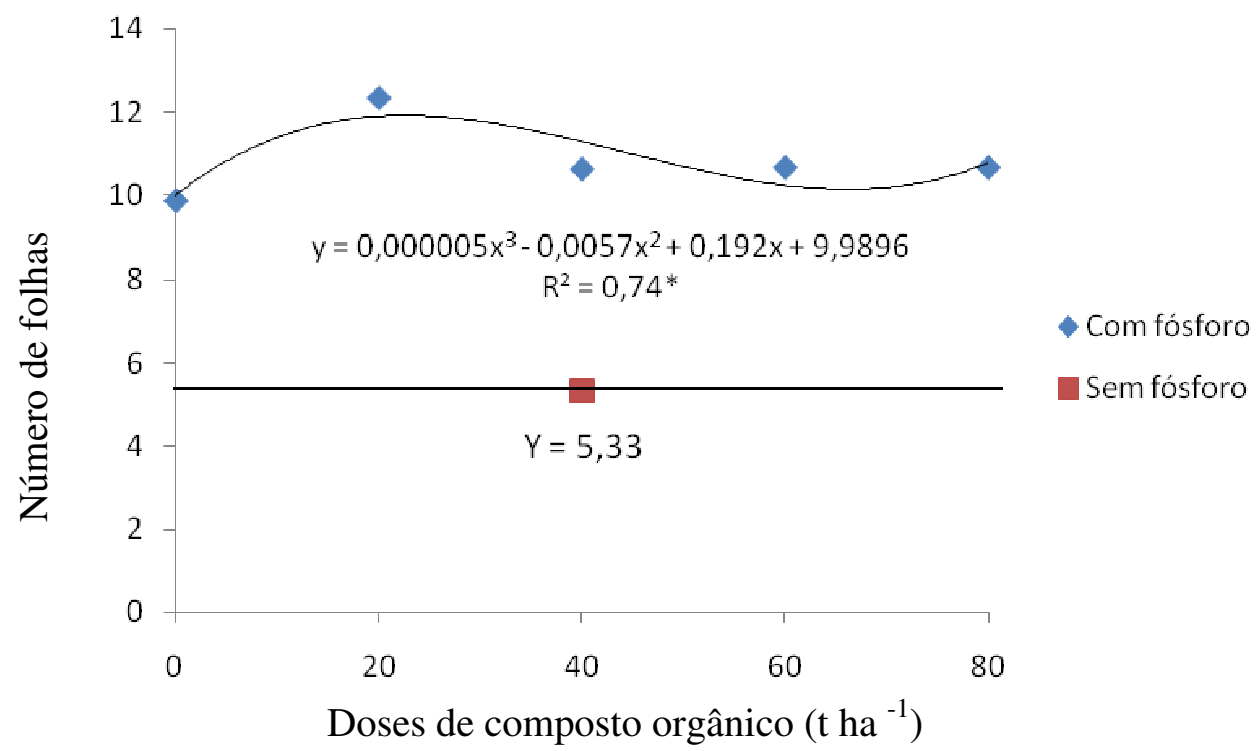

Figura 4. Número de folhas de plantas de alface aos 39 DAT em função de doses de composto orgânico, com e sem a aplicação de fósforo. FCA/UNESP. São Manoel, 2009.

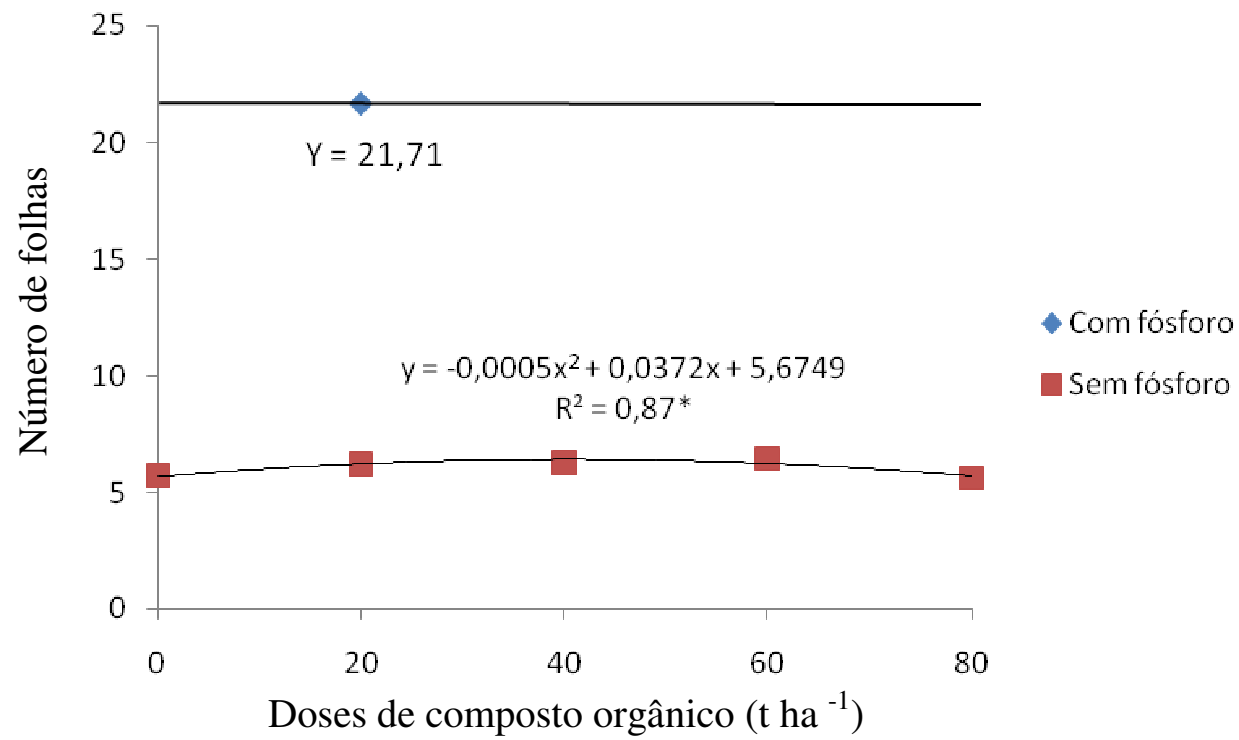

Figura 5. Número de folhas de plantas de alface aos 53 DAT em função de doses de composto orgânico, com e sem a aplicação de fósforo. FCA/UNESP. São Manoel, 2009. 


\subsubsection{Massa de matéria verde da parte aérea das plantas ao final do ciclo}

As médias de massa de matéria verde da parte aérea das plantas ao final do ciclo se ajustaram ao modelo quadrático de regressão, com máxima massa de matéria verde estimada em 96,17 e 20,94 $\mathrm{g}_{\text {planta }}{ }^{-1}$ com as doses de 57,72 $\mathrm{t} \mathrm{ha}^{-1}$ de composto orgânico com fósforo e 46,46 tha ${ }^{-1}$ de composto orgânico sem fósforo, respectivamente (Figura 6). Ao final do ciclo de produção de sementes, os valores de massa de matéria verde da parte aérea total das plantas obtidos nesse experimento variaram de 81,20 a 99,8 $\mathrm{g} \mathrm{planta}^{-1}$ para as doses de composto orgânico com fósforo e de 14,39 a 21,68 $\mathrm{g}_{\text {planta }}{ }^{-1}$ para as doses de composto orgânico sem fósforo, valores abaixo dos encontrados por Kano (2006), que obteve valores de massa verde variando de 122 a 251 g planta $^{-1}$ ao estudar doses de $\mathrm{P}_{2} \mathrm{O}_{5}$ em alface, também no final do ciclo para sementes nessa mesma cultivar.

Yuri et al. (2004), ao estudarem o efeito de composto orgânico sobre a produção e características comerciais de alface americana também observaram efeito quadrático na massa verde das plantas, na qual a produtividade máxima de 914,2 $\mathrm{g} \mathrm{planta}^{-1}$ foi obtida com a dose de 59,4 $\mathrm{t} \mathrm{ha}^{-1}$ do composto orgânico, dose semelhante a obtida neste trabalho que foi de $57,7 \mathrm{t} \mathrm{ha}^{-1}$ de composto orgânico na presença de fósforo. Fontanetti et al. (2002), ao estudarem alface americana, obtiveram a melhor resposta, em termos de rendimento de massa de matéria verde, com a dose de 40,0 t ha ${ }^{-1}$. Já Santos et al. (1994) verificaram que a máxima produção de matéria verde $\left(321,69 \mathrm{~g}\right.$ planta $\left.^{-1}\right)$ foi obtida com a dose de 65,69 $\mathrm{t} \mathrm{ha}^{-1}$ de composto orgânico. Vale ressaltar que nos adubos orgânicos não há uma uniformidade nutricional dificultando a comparação entre diferentes autores. 


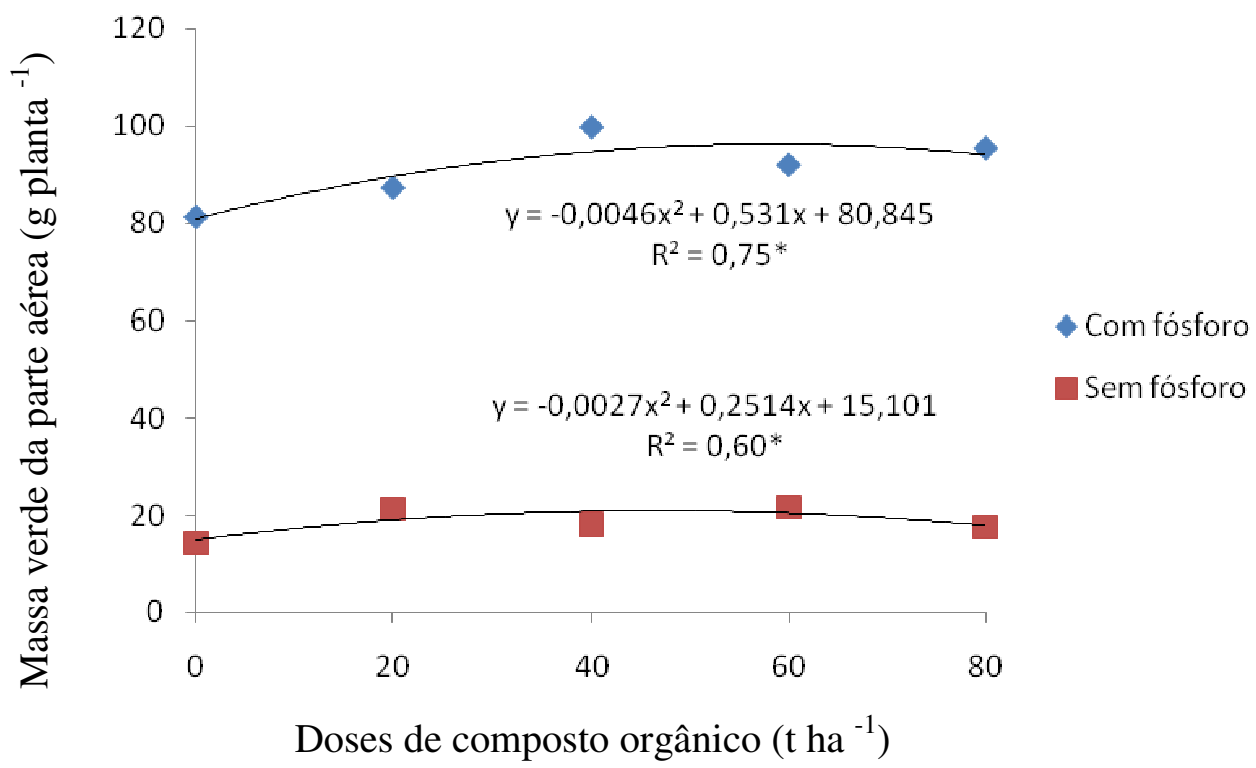

Figura 6. Massa de matéria verde da parte aérea de plantas de alface em função de doses de composto orgânico, com e sem a aplicação de fósforo. FCA/UNESP. Botucatu, 2009.

\subsubsection{Massa de matéria seca da parte aérea das plantas ao final do ciclo}

Não se observou diferença na massa de matéria seca da parte aérea das plantas ao final do ciclo nas doses de composto orgânico quando se aplicou fósforo no plantio, com média de 23,40 g planta $^{-1}$. Porém, sem a aplicação de fósforo a resposta foi linear, aumentando a massa de matéria seca das plantas conforme o aumento das doses de composto orgânico (Figura 7). Ao final do ciclo de produção de sementes, os valores de massa seca da parte aérea total das plantas obtidos variaram de 5,5 a 6,2 $\mathrm{g} \mathrm{planta}^{-1}$ para as doses de composto orgânico sem fósforo. Por estes resultados, percebe-se a fundamental importância do fósforo tanto para massa de matéria fresca como para massa de matéria seca das plantas com aumento de 4 a 5 vezes.

Kano (2006) obteve aumento linear com o acréscimo de $\mathrm{P}_{2} \mathrm{O}_{5}$ no solo, com um acúmulo de massa de matéria seca da parte aérea total variando de 35,09 a 73,41 g planta $^{-1}$ para a cultivar Verônica. Na presente pesquisa obteve-se 20,4 g planta $^{-1}$ com a aplicação de $400 \mathrm{~kg} \mathrm{ha}^{-1}$ e na ausência da aplicação de fósforo $5,13 \mathrm{~g} \mathrm{planta}^{-1}$, valores estes abaixo dos encontrados por Kano (2006), independente da presença ou ausência de adubação fosfatada. 
Souza et al. (2005) ao avaliarem características químicas de alface cultivada sob efeito residual de um solo adubado com composto orgânico, verificaram que os teores de massa de matéria seca da parte aérea da alface não foram influenciados pelas doses de composto orgânico. Diniz et al. (2008), verificaram que a quantidade de massa de matéria seca acumulada no cultivo comercial de brócolis cresceu com o aumento de doses de composto orgânico.

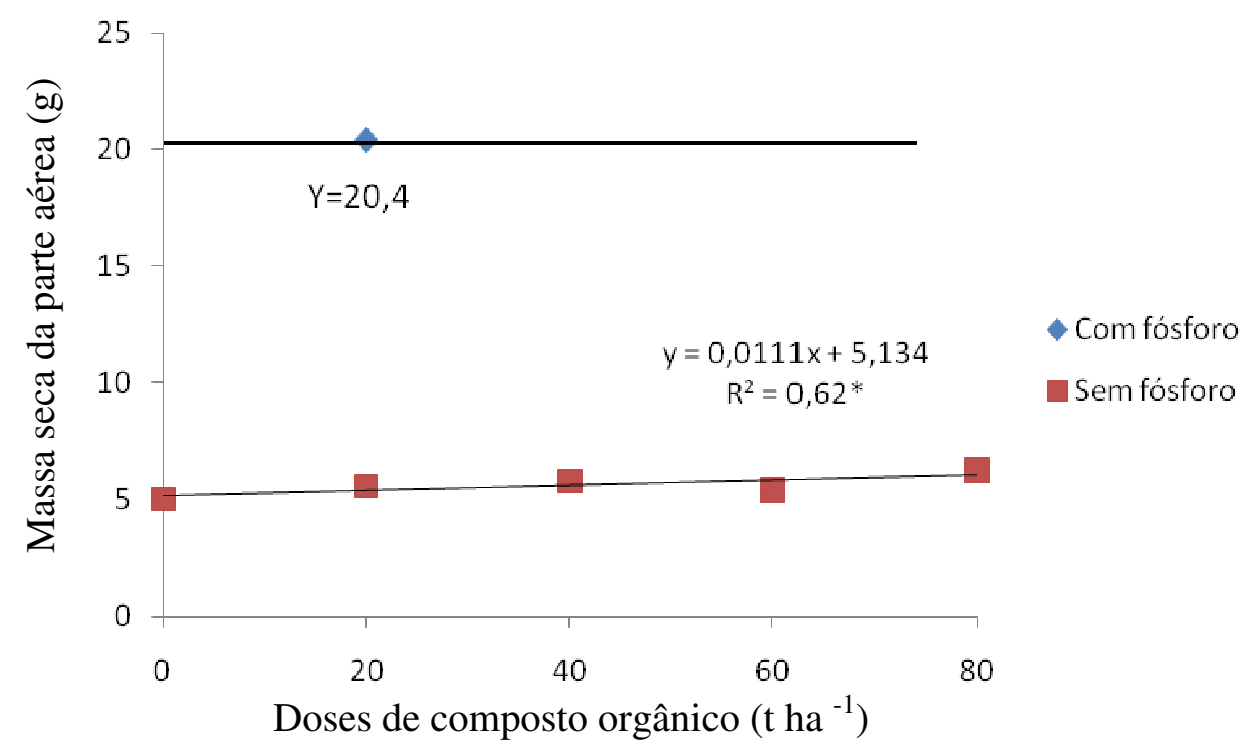

Figura 7. Massa de matéria seca da parte aérea de plantas de alface em função de doses de composto orgânico, com e sem a aplicação de fósforo. FCA/UNESP. Botucatu, 2009.

6.4. Teores de nutrientes encontrados no caule + folhas + hastes florais no final do ciclo e nas sementes

\subsubsection{Teor de macronutrientes no caule + folhas + hastes florais no final do ciclo}

Não houve interação significativa entre os fatores (composto orgânico e fósforo). Os teores dos macronutrientes fósforo, cálcio e magnésio, encontrados no caule + folhas + hastes florais das plantas foram maiores nos tratamentos com aplicação de fósforo e os de nitrogênio, potássio e enxofre apresentaram maiores teores sem aplicação de fósforo (Tabela 13). A explicação para o que ocorreu para esses últimos nutrientes pode ser explicado pelo efeito de diluição, ou seja, a adição de fósforo no solo favoreceu o desenvolvimento da 
planta e com isso, nitrogênio, potássio e enxofre diluíram por uma maior produção de massa da planta, ressaltando que não foram realizadas adubações em cobertura com nitrogênio e potássio.

A diminuição no teor de potássio com o aumento do fornecimento de fósforo no solo também foi verificado em alface para consumo de folhas por Claassens (1994) e por Kano (2006) em alface para produção de sementes.

O aumento no teor de fósforo nas plantas em função da aplicação de adubação fosfatada também foi verificado em plantas de alface para consumo de folhas, por Claassens (1994), Sanchez \& El Hout (1995) e Arruda Júnior et al. (2005) e em plantas de alface para produção de sementes por Kano (2006).

As doses de composto orgânico utilizadas não influenciaram os teores de nitrogênio, potássio, cálcio, magnésio e enxofre encontrados no caule + folhas + hastes florais das plantas, no entanto, afetaram o teor de fósforo (Tabela 14). Rici et al. (1995) não observaram efeito significativo nos teores dos macronutrientes nitrogênio, fósforo, potássio, cálcio, magnésio e enxofre em duas cultivares de alface ao estudar o efeito da adubação orgânica sobre os teores destes nutrientes.

$\mathrm{O}$ teor de fósforo aumentou linearmente com o aumento do fornecimento de composto orgânico, com e sem fósforo, aplicados no solo (Figura 10). Os níveis de fósforo já existentes no solo e os liberados durante a mineralização do composto orgânico certamente garantiram este suprimento mesmo nos tratamentos onde foi aplicado 400 $\mathrm{kg} \mathrm{ha}^{-1}$ de $\mathrm{P}_{2} \mathrm{O}_{5}$. Vidigal et al. (1995) e Souza et al. (2005), estudando a resposta da alface ao efeito residual do composto orgânico, também constataram aumentos nos teores de fósforo com o incremento das doses aplicadas.

A ordem decrescente do teor dos macronutrientes obtidos no caule + folhas + hastes florais das plantas foi: potássio $>$ cálcio $>$ nitrogênio $>$ magnésio $>$ fósforo $>$ enxofre. Os nutrientes com maiores teores foram cálcio que é imóvel (não translocável) e o potássio com cerca do dobro do nitrogênio que é móvel (translocável) e quase oito vezes o teor de fósforo. Kano (2006) ao avaliar doses de fósforo no teor de macronutrientes encontrados no caule + folhas + hastes florais de plantas de alface também obteve a seguinte ordem: potássio $>$ cálcio nitrogênio > magnésio > fósforo > enxofre. Já Raij et al. (1997) relatou a seguinte ordem decrescente de nutrientes nas folhas: potássio $>$ nitrogênio $>$ cálcio $>$ fósforo 
magnésio > enxofre Beninni (2002) também verificou o maior teor de potássio $\left(78,33 \mathrm{~g} \mathrm{~kg}^{-1}\right)$ em plantas de alface cultivar Verônica (para o consumo de folhas) seguido pelo teor de nitrogênio $\left(38,24 \mathrm{~g} \mathrm{~kg}^{-1}\right)$, cálcio $\left(12,23 \mathrm{~g} \mathrm{~kg}^{-1}\right)$, fósforo $\left(5,74 \mathrm{~g} \mathrm{~kg}^{-1}\right)$, enxofre $\left(3,87 \mathrm{~g} \mathrm{~kg}^{-1}\right)$ e magnésio $\left(3,11 \mathrm{~g} \mathrm{~kg}^{-1}\right)$. Os valores encontrados por esse autor estão acima dos obtidos neste experimento para nitrogênio, fósforo e potássio, e menores para os teores de cálcio, magnésio e enxofre.

Pode-se observar neste experimento que em função com aumento do ciclo ocasionado em plantas para a produção de sementes, alguns teores foram bem abaixo àqueles encontrados em alface para o consumo de folhas. É provável que isto tenha ocorrido em função da ausência de adubação de cobertura durante a condução do experimento, onde somente as doses de composto orgânico utilizadas como tratamento talvez não tenham sido suficientes para o suprimento destes nutrientes para as plantas de alface, além de ter ocorrido translocação dos nutrientes móveis das folhas para as sementes.

Kano (2006) ao utilizar a dose de $400 \mathrm{~kg} \mathrm{ha}^{-1}$ de $\mathrm{P}_{2} \mathrm{O}_{5}$, obteve teores médios ( $\mathrm{em} \mathrm{g} \mathrm{kg}^{-1}$ ) na parte aérea da planta (caule + folhas + hastes florais), no final do ciclo para a produção de sementes, de nitrogênio, fósforo, potássio, cálcio, magnésio e enxofre de $15 ; 1,5 ; 37,8 ; 16,9 ; 2,5$ e 0,9 , respectivamente em plantas de alface cultivar Verônica. Os valores encontrados por este autor estão acima dos obtidos neste experimento (comparando apenas os tratamentos com aplicação de fósforo) para nitrogênio e potássio, e menores para os teores de cálcio, magnésio e enxofre. Já para fósforo os teores foram semelhantes.

Tabela 13. Teor de nitrogênio, fósforo, potássio, cálcio, magnésio e enxofre $\left(\mathrm{g} \mathrm{kg}^{-1}\right)$ obtidos no caule + folhas + hastes florais das plantas de alface no final no ciclo para a produção de sementes, em função de tratamentos com e sem aplicação de fósforo. FCA/UNESP, São Manuel-SP, 2009.

\begin{tabular}{lcccccc}
\hline Tratamento & $\mathrm{N}$ & $\mathrm{P}$ & $\mathrm{K}$ & $\mathrm{Ca}$ & $\mathrm{Mg}$ & $\mathrm{S}$ \\
$\left(\mathrm{kg} \mathrm{ha}^{-1} \mathrm{P}_{2} \mathrm{O}_{5}\right)$ & - & & & & \\
\hline Com fósforo & $10,90 \mathrm{~b}$ & $1,65 \mathrm{a}$ & $17,85 \mathrm{~b}$ & $25,15 \mathrm{a}$ & $6,40 \mathrm{a}$ & $1,35 \mathrm{~b}$ \\
Sem fósforo & $13,10 \mathrm{a}$ & $0,91 \mathrm{~b}$ & $33,30 \mathrm{a}$ & $20,20 \mathrm{~b}$ & $5,67 \mathrm{~b}$ & $1,61 \mathrm{a}$ \\
\hline $\mathrm{CV}(\%)$ & 11,51 & 13,57 & 12,48 & 15,08 & 16,49 & 9,48 \\
\hline
\end{tabular}

$\mathrm{CV}=$ coeficiente de variação. Médias seguidas por mesma letra, nas colunas, não diferem entre si pelo teste $\mathrm{F}$ a $5 \%$ de probabilidade. 
Tabela 14. Teor de nitrogênio, fósforo, potássio, cálcio, magnésio e enxofre $\left(\mathrm{g} \mathrm{kg}^{-1}\right)$ obtidos no caule + folhas + hastes florais das plantas de alface no final no ciclo para a produção de sementes, em função de doses de composto orgânico. FCA/UNESP, São Manuel-SP, 2009.

\begin{tabular}{|c|c|c|c|c|c|c|}
\hline \multirow{2}{*}{$\begin{array}{c}\text { Tratamento } \\
\text { (t ha }{ }^{-1} \text { de composto) }\end{array}$} & $\mathrm{N}$ & $\mathrm{P}^{*}$ & $\mathrm{~K}$ & $\mathrm{Ca}$ & $\mathrm{Mg}$ & $\mathrm{S}$ \\
\hline & \multicolumn{6}{|c|}{ 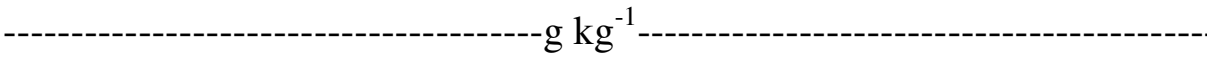 } \\
\hline T0 & $12,38 \mathrm{a}$ & 1,09 & $23,00 \mathrm{a}$ & 23,38 a & $6,55 \mathrm{a}$ & $1,50 \mathrm{a}$ \\
\hline $\mathrm{T} 20$ & $12,00 \mathrm{a}$ & 1,30 & 26,88 a & 23,63 a & $6,65 \mathrm{a}$ & $1,55 \mathrm{a}$ \\
\hline $\mathrm{T} 40$ & 12,38 a & 1,29 & $24,63 \mathrm{a}$ & $22,00 \mathrm{a}$ & $5,91 \mathrm{a}$ & $1,35 \mathrm{a}$ \\
\hline T60 & $11,38 \mathrm{a}$ & 1,35 & 27,13 a & $22,75 \mathrm{a}$ & $5,57 \mathrm{a}$ & $1,55 \mathrm{a}$ \\
\hline T80 & $11,88 \mathrm{a}$ & 1,38 & $26,25 \mathrm{a}$ & $21,63 \mathrm{a}$ & $5,50 \mathrm{a}$ & $1,46 \mathrm{a}$ \\
\hline $\mathrm{CV}(\%)$ & 11,51 & 13,57 & 12,48 & 15,08 & 16,49 & 9,48 \\
\hline
\end{tabular}

$\mathrm{CV}=$ coeficiente de variação. Médias seguidas por mesma letra, nas colunas, não diferem entre si pelo teste de Tukey a $5 \%$ de probabilidade. $*$ = significativo pelo teste $\mathrm{F}$ a $5 \%$ de probabilidade.

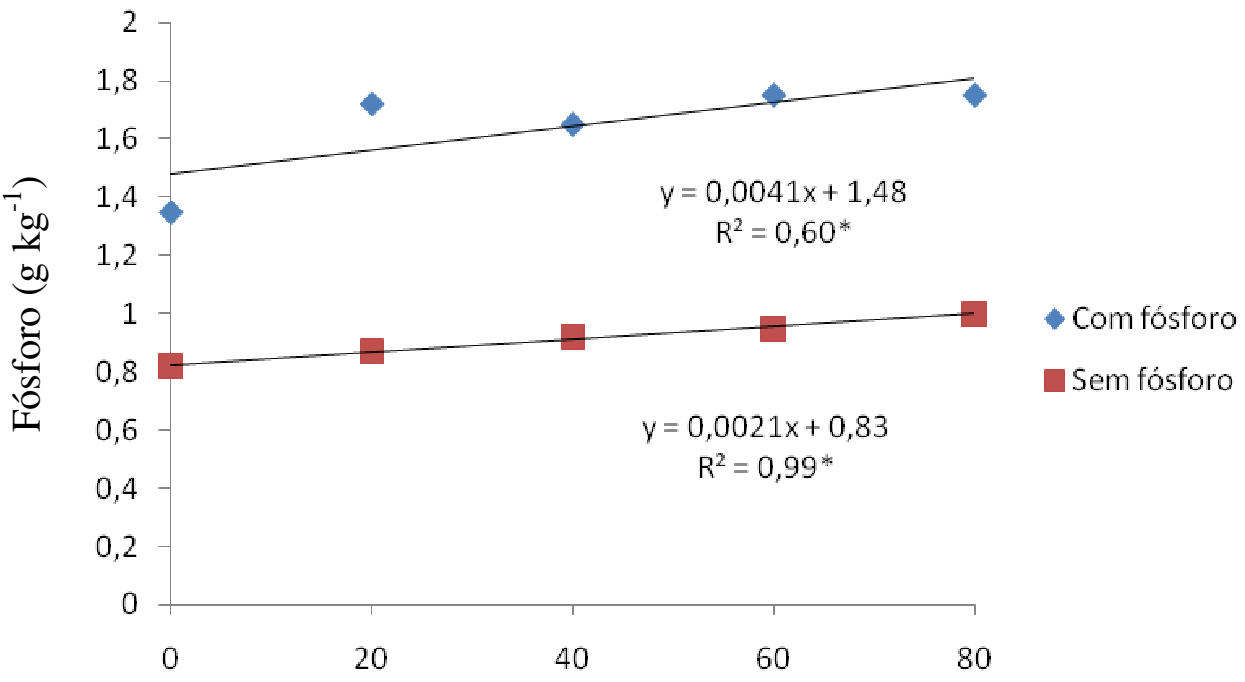

Doses de composto orgânico $\left(\mathrm{t} \mathrm{ha}^{-1}\right)$

Figura 10. Teor de fósforo no caule + folhas + hastes florais da planta de alface no final do ciclo para a produção de sementes, em função das doses de composto orgânico com e sem aplicação de fósforo no solo. FCA/UNESP, São Manuel-SP, 2009.

\subsubsection{Teor de micronutrientes no caule + folhas + hastes florais no final do ciclo}

Não houve interação significativa entre os fatores (composto orgânico e fósforo). Os teores dos micronutrientes cobre e zinco, encontrados no caule + folhas + hastes florais das plantas foram maiores nos tratamentos sem aplicação de fósforo e boro, ferro e 
manganês não apresentaram diferença estatística entre os tratamentos com e sem aplicação de fósforo ao solo (Tabela 15). Claassens (1994) verificou que o teor de micronutrientes em alface para consumo de folhas com baixo fornecimento de fósforo também foi maior e atribuíram isso ao efeito de concentração, devido as menores produções de massa verde pela planta em baixas concentrações de fósforo.

As doses de composto orgânico utilizadas não influenciaram os teores de boro, cobre, ferro e manganês encontrados no caule + folhas + hastes florais das plantas, no entanto, afetaram o teor de zinco (Tabela 16).

Não se observou diferença no teor de zinco no caule + folhas + hastes florais das plantas nas doses de composto orgânico quando se aplicou fósforo no plantio, com média de $19,75 \mathrm{mg} \mathrm{kg}^{-1}$. Porém, sem a aplicação de fósforo a resposta foi linear, aumentando o teor de zinco no caule + folhas + hastes das plantas conforme o aumento das doses de composto orgânico (Figura 11). O fósforo promove inibição não competitiva com o zinco (MALAVOLTA et al., 1997); dessa forma, a adubação fosfatada reduziu os teores de zinco ao compará-los com o teor de zinco nos tratamentos sem aplicação de fósforo.

A ordem decrescente dos teores dos micronutrientes encontrados no caule + folhas + hastes florais foi: ferro $>$ manganês $>$ boro $>$ zinco $>$ cobre. Magro (2009) ao avaliar doses de composto orgânico no teor de micronutrientes nas folhas de brócolis para produção de sementes, também obteve a mesma ordem: ferro $>$ manganês $>$ boro $>$ zinco $>$ cobre. Já Kano (2006), ao avaliar doses de fósforo no teor de micronutrientes encontrados no caule + folhas + hastes florais de plantas de alface para produção de sementes, obteve a seguinte ordem: ferro $>$ manganês $>$ zinco $>$ boro $>$ cobre. Comparando com a atual pesquisa, observa-se apenas a inversão de ordem entre boro e zinco.

Os teores de micronutrientes (sem aplicação de fósforo) obtidos na parte aérea das plantas foram semelhantes àqueles teores apresentados por Raij et al. (1997) em folhas de alface para consumo, com exceção para o ferro em que o teor foi superior ao valor da faixa considerada ideal e zinco com aplicação de fósforo que foi abaixo da faixa considerada ideal por esses autores.

Rici et al. (1995) não observaram efeito significativo nos teores de micronutrientes boro, cobre, ferro, manganês e zinco em duas cultivares de alface ao estudar efeito de adubação orgânica sobre os teores destes nutrientes. 
Tabela 15. Teor de boro, cobre, ferro, manganês e zinco $\left(\mathrm{mg} \mathrm{kg}^{-1}\right)$ obtidos no caule + folhas + hastes florais das plantas de alface no final no ciclo para a produção de sementes, em função de tratamentos com e sem aplicação de fósforo. FCA/UNESP, São Manuel-SP, 2009.

\begin{tabular}{lccccc}
\hline $\begin{array}{l}\text { Tratamento } \\
\left(\mathrm{kg} \mathrm{ha}^{-1} \mathrm{P}_{2} \mathrm{O}_{5}\right)\end{array}$ & $\mathrm{B}$ & $\mathrm{Cu}$ & $\mathrm{Fe}$ & $\mathrm{Mn}$ & $\mathrm{Zn}$ \\
\hline Com fósforo & $47,75 \mathrm{a}$ & $6,45 \mathrm{~b}$ & $609,60 \mathrm{a}$ & $101,70 \mathrm{a}$ & $14,85 \mathrm{~b}$ \\
Sem fósforo & $47,25 \mathrm{a}$ & $10,75 \mathrm{a}$ & $551,95 \mathrm{a}$ & $97,55 \mathrm{a}$ & $39,75 \mathrm{a}$ \\
\hline $\mathrm{CV}(\%)$ & 20,51 & 10,00 & 25,81 & 23,83 & 25,87 \\
\hline
\end{tabular}

$\mathrm{CV}=$ coeficiente de variação. Médias seguidas por mesma letra, nas colunas, não diferem entre si pelo teste $\mathrm{F}$ a $5 \%$ de probabilidade.

Tabela 16. Teor de boro, cobre, ferro, manganês e zinco $\left(\mathrm{mg} \mathrm{kg}^{-1}\right)$ obtidos no caule + folhas + hastes florais das plantas de alface no final no ciclo para a produção de sementes, em função de doses de composto orgânico. FCA/UNESP, São Manuel-SP, 2009.

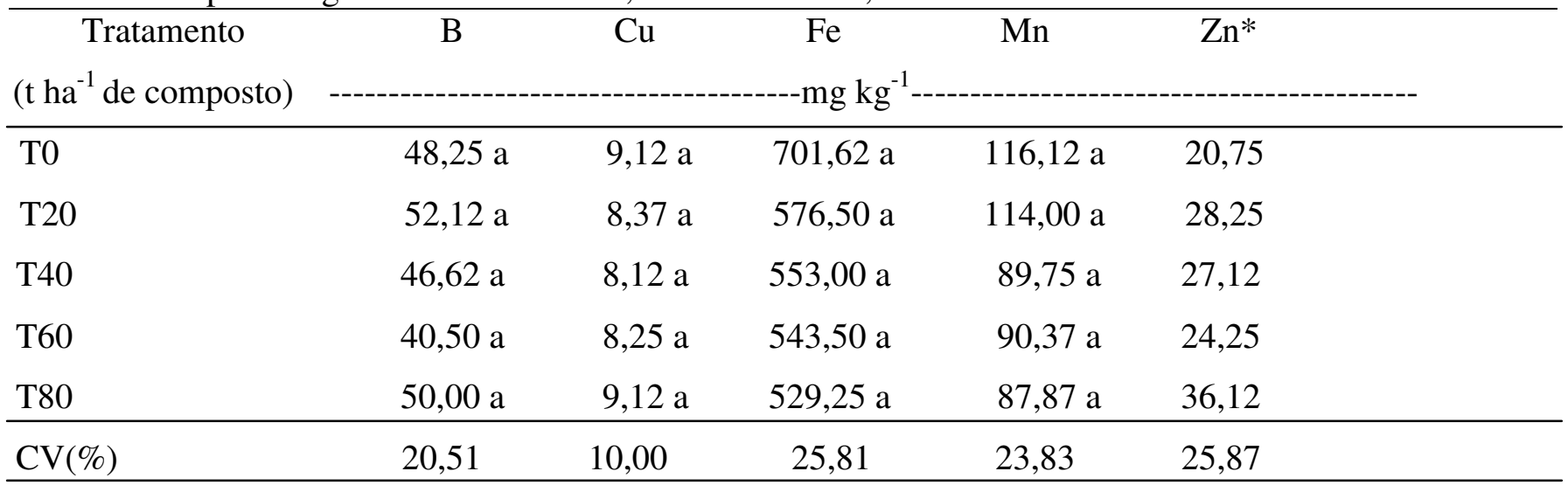

$\mathrm{CV}=$ coeficiente de variação. Médias seguidas por mesma letra, nas colunas, não diferem entre si pelo teste de Tukey a $5 \%$ de probabilidade. $*=$ significativo pelo teste $\mathrm{F}$ a $5 \%$ de probabilidade. 


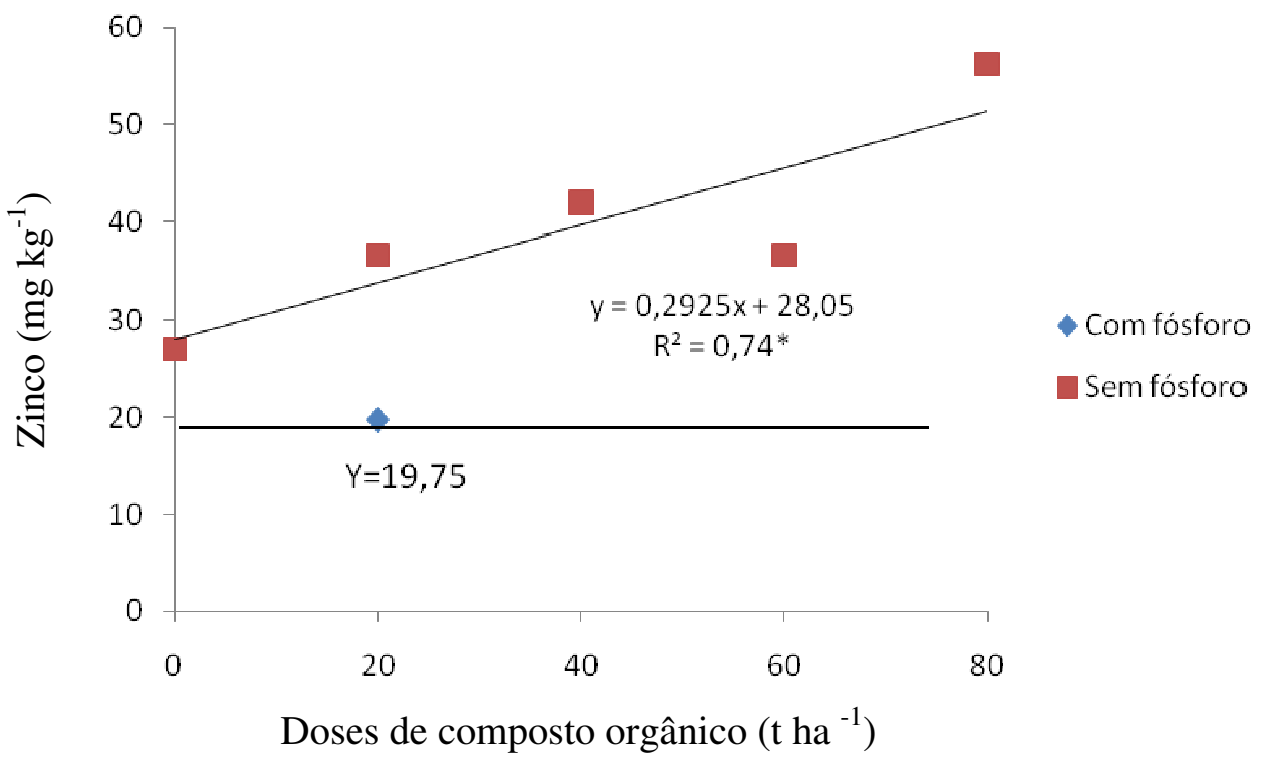

Figura 11. Teor de zinco no caule + folhas + hastes florais da planta de alface no final do ciclo para a produção de sementes, em função das doses de composto orgânico com e sem aplicação de fósforo no solo. FCA/UNESP, São Manuel-SP, 2009.

\subsubsection{Teor de macronutrientes nas sementes}

Não houve interação significativa entre os fatores (composto orgânico e fósforo). Os teores de fósforo, potássio, cálcio, magnésio e enxofre nas sementes foram maiores com a aplicação de fósforo, mas não houve diferença significativa para o teor de nitrogênio (Tabela 17).

Kano (2006), ao avaliar a produção e qualidade de sementes de alface cultivar Verônica, verificou que os teores dos macronutrientes contidos nas sementes não foram influenciados pelas doses de $\mathrm{P}_{2} \mathrm{O}_{5}$ fornecidas às plantas. Portanto, os resultados observados na atual pesquisa são diferentes dos deste autor.

Carvalho (1978), ao avaliar o efeito da adubação nitrogenada na produção e qualidade de sementes de alface, verificou que o teor de nitrogênio nas sementes não foi influenciada pela adubação nitrogenada.

Fornasieri Filho et al. (1988), em milho pipoca, e Zucareli (2005), em feijão obtiveram aumento linear no teor de fósforo nas sementes em função de doses crescentes de $\mathrm{P}_{2} \mathrm{O}_{5}$ fornecidas no solo. 
Vieira (1986) obteve aumento no teor de fósforo na semente de feijão com o aumento do fornecimento deste nutriente no solo, porém não obteve diferenças nos teores de potássio e cálcio. Ainda em feijão, Ramos Júnior et al. (2003) não obtiveram respostas à adubação fosfatada quanto ao teor de cálcio e de fósforo nas sementes da cultivar IAC Carioca.

O magnésio é um elemento móvel na planta e pelo fato de ser carregador do fósforo na planta, possui interação com esse nutriente, atua como co-fator de enzimas ligadas ao metabolismo de fósforo (MALAVOLTA et al., 1997). Talvez por isso, a aplicação de fósforo, ocasionou o aumento no teor de magnésio na semente. Além disso, na semente, o magnésio juntamente com outros nutrientes como o fósforo, é armazenado nos sais do ácido fítico, constituindo a fitina (COPELAND \& MCDONALD, 1995; MARSCHNER, 1995).Vieira (1986) e Ramos Júnior et al. (2003) em sementes de feijão e Vieira et al. (1987) em sementes de soja obtiveram aumento no teor de magnésio nas sementes em função do fornecimento de $\mathrm{P}_{2} \mathrm{O}_{5}$ no solo.

As doses de composto orgânico utilizadas não influenciaram os teores de nitrogênio, fósforo, cálcio, magnésio e enxofre encontrados nas sementes, no entanto, afetaram o teor de potássio (Tabela 18).

As médias do teor de potássio na semente para os tratamentos de composto orgânico com aplicação de fósforo se ajustaram ao modelo linear. Para as doses de composto orgânico sem fósforo não observou-se diferença entre os tratamentos, com média de $5,75 \mathrm{~g} \mathrm{~kg}^{-1}$ (Figura 12). Normalmente o potássio é o nutriente mais rapidamente disponibilizado às plantas com a adubação orgânica (SOUZA \& RESENDE, 2003) e neste experimento observou-se aumento no teor de potássio conforme o aumento das doses de composto orgânico, assim como aumento no teor de potássio no solo (Tabela 5).

Observa-se que nas sementes o teor de nutrientes decresceu na seguinte ordem: nitrogênio $>$ fósforo $>$ potássio $>$ cálcio $>$ magnésio $>$ enxofre. Kano (2006) ao avaliar doses de fósforo no teor de macronutrientes nas sementes de alface obteve a seguinte ordem: nitrogênio $>$ fósforo $>$ potássio $>$ magnésio $>$ cálcio $>$ enxofre, onde a única diferença é a inversão de posição entre cálcio e magnésio. Porém, numericamente, os valores nos teores destes dois nutrientes foram muito próximos (Tabela 18). Lott et al. (1995), em uma 
revisão com sementes de várias culturas, descrevem que entre os macronutrientes avaliados, o teor de nitrogênio foi o encontrado em maior concentração nas sementes, resultado semelhante ao obtido em sementes de feijão, por Vieira (1986) e Ramos Júnior et al. (2003). Em sementes de soja, Vieira et al. (1987), ao determinaram apenas os teores de fósforo, cálcio e magnésio, obtiveram um maior teor de fósforo, seguido pelo magnésio, e por último o cálcio.

Os teores de nitrogênio, fósforo, potássio, cálcio, magnésio e enxofre obtidos por Kano (2006) foram aproximadamente de 45,2;8,9;6,9; 2,7; 3,7 e 1,9 $\mathrm{g} \mathrm{kg}^{-1}$, respectivamente, valores semelhantes aos obtidos neste experimento, o que mostra que o suprimento de nutrientes para sementes foi satisfatório no presente experimento'.

Pode-se verificar que os teores de nitrogênio e fósforo encontrados na semente (Tabelas 17 e 18) foram superiores àqueles presente no caule + folhas + hastes florais (Tabelas 13 e 14). Isso demonstra novamente a mobilidade desses nutrientes na planta. $\mathrm{O}$ maior teor desses nutrientes nas sementes do que nas folhas e caule também foi observado para alface por Kano et al. (2006).

Para potássio, cálcio, magnésio e enxofre, nota-se os menores teores encontrados na semente em relação àqueles obtidos no caule + folhas + hastes florais. Para o cálcio e o enxofre ocorreu provavelmente devido à sua baixa mobilidade pelo floema (MALAVOLTA et al., 1997).

Tabela 17. Teor de nitrogênio, fósforo, potássio, cálcio, magnésio e enxofre $\left(\mathrm{g} \mathrm{kg}^{-1}\right)$ obtidos nas sementes em função de tratamentos com e sem aplicação de fósforo. FCA/UNESP, São ManuelSP, 2009.

\begin{tabular}{lcccccc}
\hline Tratamento & $\mathrm{N}$ & $\mathrm{P}$ & $\mathrm{K}$ & $\mathrm{Ca}$ & $\mathrm{Mg}$ & $\mathrm{S}$ \\
$\left(\mathrm{kg} \mathrm{ha}^{-1} \mathrm{P}_{2} \mathrm{O}_{5}\right)$ & - & & \\
\hline Com fósforo & $44,40 \mathrm{a}$ & $7,42 \mathrm{a}$ & $6,75 \mathrm{a}$ & $3,80 \mathrm{a}$ & $3,58 \mathrm{a}$ & $2,46 \mathrm{a}$ \\
Sem fósforo & $45,65 \mathrm{a}$ & $4,96 \mathrm{~b}$ & $5,45 \mathrm{~b}$ & $3,10 \mathrm{~b}$ & $3,01 \mathrm{~b}$ & $1,82 \mathrm{~b}$ \\
\hline $\mathrm{CV}$ & 4,33 & 7,94 & 8,58 & 10,44 & 6,44 & 5,14 \\
\hline
\end{tabular}

$\mathrm{CV}=$ coeficiente de variação. Médias seguidas por mesma letra, nas colunas, não diferem entre si pelo teste $\mathrm{F}$ a $5 \%$ de probabilidade. 
Tabela 18. Teor de nitrogênio, fósforo, potássio, cálcio, magnésio e enxofre $\left(\mathrm{g} \mathrm{kg}^{-1}\right)$ obtidos nas sementes em função de doses de composto orgânico. FCA/UNESP, São Manuel-SP, 2009.

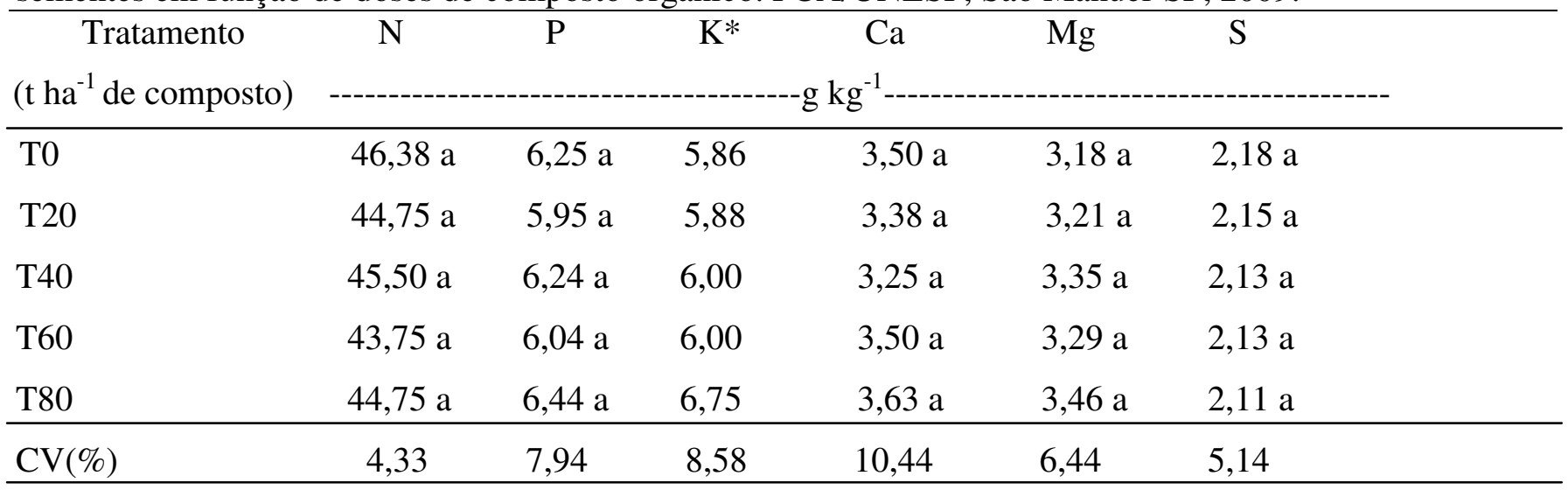

$\mathrm{CV}=$ coeficiente de variação. Médias seguidas por mesma letra, na coluna, não diferem entre si pelo teste de Tukey a $5 \%$ de probabilidade. $*$ = significativo pelo teste $\mathrm{F}$ a $5 \%$ de probabilidade.

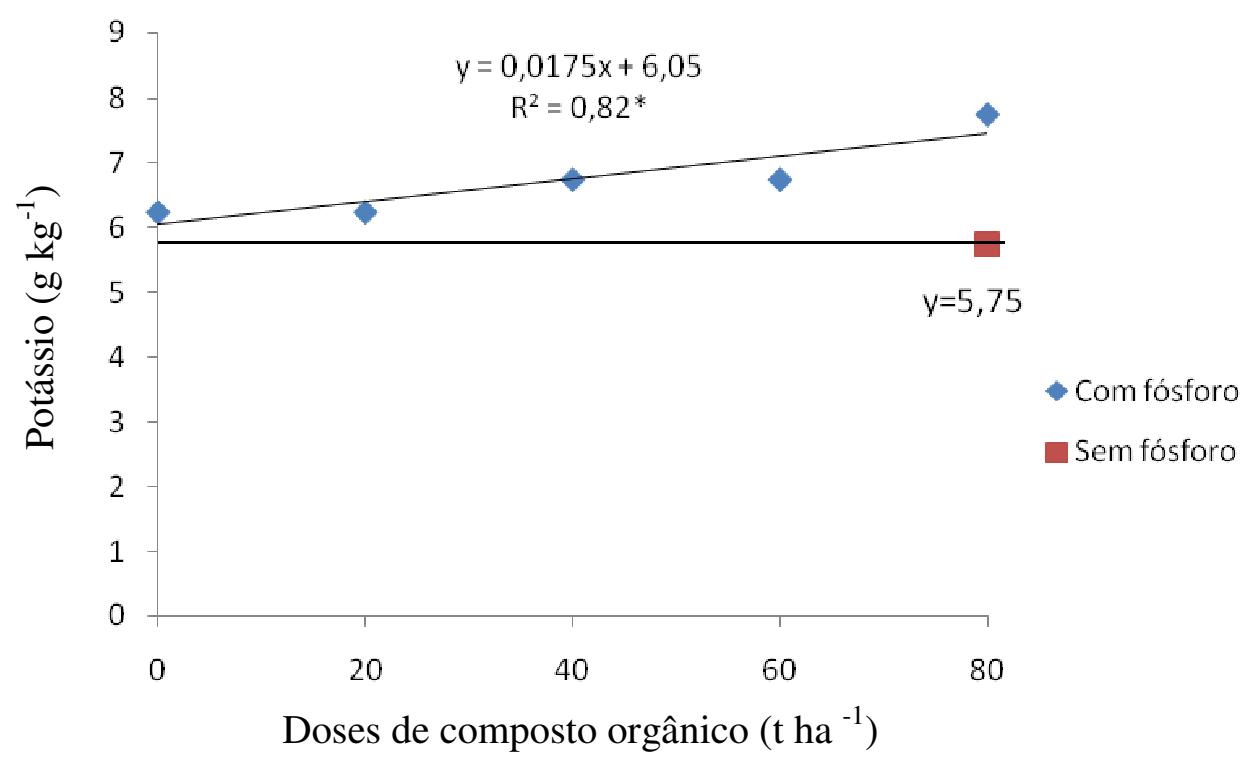

Figura 12. Teor de potássio nas sementes de alface em função das doses de composto orgânico com e sem aplicação de fósforo no solo. FCA/UNESP, São Manuel-SP, 2009.

\subsubsection{Teor de micronutrientes nas sementes}

Não houve interação significativa entre os fatores (composto orgânico e fósforo). Nos tratamentos sem aplicação de fósforo os teores de boro, cobre, ferro, manganês e zinco nas sementes foram superiores em relação aos com aplicação de fósforo (Tabela 19). A explicação para o que ocorreu para esses nutrientes pode ser explicado pelo efeito de diluição, 
ou seja, a presença de fósforo no solo favoreceu o desenvolvimento da planta e, com isso, boro, cobre, ferro, manganês e zinco foram diluidos por uma massa maior da planta. Já Kano (2006), ao avaliar a produção de sementes de alface cultivar Verônica, verificou que os teores dos micronutrientes contidos nas sementes foram influenciados pela adição de $\mathrm{P}_{2} \mathrm{O}_{5}$ fornecidas às plantas, obtendo alterações significativas nos teores de boro, cobre, ferro, manganês e zinco que ajustaram-se à equação quadrática.

Ramos Júnior et al. (2003) verificaram que o uso de doses de $\mathrm{P}_{2} \mathrm{O}_{5}$ no solo não afetaram o teor de cobre, ferro, manganês e zinco em sementes de feijão. Resultado semelhante foi obtido por Fornasieri Filho et al. (1988) que concluíram que o teor de zinco nas sementes de milho pipoca não foi influenciado pela adubação fosfatada.

As doses de composto orgânico utilizadas não influenciaram os teores de boro, cobre e manganês encontrados nas sementes, no entanto, afetaram os teores de ferro e zinco (Tabela 20).

As médias do teor de ferro na semente para os tratamentos de composto orgânico com e sem aplicação de fósforo se ajustaram ao modelo de linear (Figura 13), assim quanto menor a dose de composto orgânico maior o teor de ferro na semente. Apesar da grande absorção de ferro o teor deste elemento foi inferior nas sementes (Tabela 20) em relação ao restante da planta (Tabela 16).

Já as médias do teor de zinco na semente para os tratamentos com e sem aplicação de fósforo se ajustaram ao modelo quadrático de regressão, com mínimos teores estimados em 50,25 e 107,11 $\mathrm{mg} \mathrm{kg}^{-1}$ nas doses de 13,17 $\mathrm{t} \mathrm{ha}^{-1}$ de composto orgânico com fósforo e 32,20 t ha ${ }^{-1}$ de composto orgânico sem fósforo (Figura 14).

O teor de zinco nas sementes foi cerca de três vezes maior e o de cobre duas vezes maior que o encontrado no caule + folha + hastes florais. Já os teores de boro e ferro são duas vezes menor nas sementes e manganês três vezes menor (Tabelas 15 e 19). Comparando os tratamentos com e sem aplicação de fósforo observa-se que com fósforo os teores foram sempre inferiores para todas as doses de composto orgânico O fósforo promove inibição não competitiva com o zinco (MALAVOLTA et al., 1997), dessa forma, a presença da adubação fosfatada promoveu reduções nos teores de zinco, além do efeito de diluição. Resultado diferente foi observado por Vieira (1986), com aumento no teor de zinco na semente de feijão com o aumento do fornecimento de fósforo no solo. 
Os teores de ferro e zinco também foram alterados em sementes de feijão, ajustando-se a uma equação quadrática inversa com o aumento de doses de $\mathrm{P}_{2} \mathrm{O}_{5}$ (ZUCARELI, 2005).

A ordem decrescente dos teores dos micronutrientes encontrados nas sementes foi: ferro $>$ zinco $>$ manganês $>$ boro $>$ cobre. Carvalho \& Nakagawa (2000) citam que em sementes de algumas variedades botânicas de Brassica oleraceae L. também foi encontrado essa mesma ordem decrescente. Resultado semelhante foi obtido por Ramos Júnior et al. (2003a) e Zucareli (2005) nas sementes de feijão em que também obtiveram essa mesma ordem, exceto para o boro que não foi determinado. Kano (2006) ao avaliar doses de fósforo no teor de micronutrientes nas sementes de alface, também obteve essa mesma ordem decrescente, exceto para o teor de boro que foi maior que o de cobre.

Tabela 19. Teor de boro, cobre, ferro, manganês e zinco $\left(\mathrm{mg} \mathrm{kg}^{-1}\right)$ obtidos nas sementes de alface em função de tratamentos com e sem aplicação de fósforo. FCA/UNESP, São Manuel-SP, 2009.

\begin{tabular}{lccccc}
\hline $\begin{array}{l}\text { Tratamento } \\
\left(\mathrm{kg} \mathrm{ha}^{-1} \mathrm{P}_{2} \mathrm{O}_{5}\right)\end{array}$ & $\mathrm{B}$ & $\mathrm{Cu}$ & $\mathrm{Fe}$ & $\mathrm{Mn}$ & $\mathrm{Zn}$ \\
\hline Com fósforo & $23,20 \mathrm{~b}$ & $10,75 \mathrm{~b}$ & $188,90 \mathrm{~b}$ & $26,2 \mathrm{~b}$ & $59,45 \mathrm{~b}$ \\
$\mathrm{Sem}$ fósforo & $29,85 \mathrm{a}$ & $22,00 \mathrm{a}$ & $246,75 \mathrm{a}$ & $31,70 \mathrm{a}$ & $112,90 \mathrm{a}$ \\
\hline $\mathrm{CV}(\%)$ & 26,72 & 8,95 & 8,22 & 6,88 & 11,13 \\
\hline
\end{tabular}

$\mathrm{CV}=$ coeficiente de variação. Médias seguidas por mesma letra, nas colunas, não diferem entre si pelo teste $\mathrm{F}$ a $5 \%$ de probabilidade.

Tabela 20. Teor de boro, cobre, ferro, manganês e zinco $\left(\mathrm{mg} \mathrm{kg}^{-1}\right)$ obtidos nas sementes de alface em função de doses de composto orgânico. FCA/UNESP, São Manuel-SP, 2009.

\begin{tabular}{lccccc}
\hline \multicolumn{1}{c}{ Tratamento } & B & Cu & Fe* & Mn & Zn* \\
(t ha ${ }^{-1}$ de composto) & - & & & \\
\hline T0 & $32,75 \mathrm{a}$ & $16,50 \mathrm{a}$ & 244,50 & $30,37 \mathrm{a}$ & 82,62 \\
T20 & $23,00 \mathrm{a}$ & $15,62 \mathrm{a}$ & 212,12 & $29,25 \mathrm{a}$ & 77,62 \\
T40 & $29,00 \mathrm{a}$ & $16,62 \mathrm{a}$ & 213,25 & $28,25 \mathrm{a}$ & 86,62 \\
T60 & $24,25 \mathrm{a}$ & $15,62 \mathrm{a}$ & 209,62 & $28,75 \mathrm{a}$ & 82,12 \\
T80 & $23,62 \mathrm{a}$ & $17,50 \mathrm{a}$ & 209,62 & $28,12 \mathrm{a}$ & 101,87 \\
\hline $\mathrm{CV}(\%)$ & 26,72 & 8,95 & 8,22 & 6,88 & 11,13 \\
\hline
\end{tabular}

$\mathrm{CV}=$ coeficiente de variação. Médias seguidas por mesma letra, nas colunas, não diferem entre si pelo teste de Tukey a $5 \%$ de probabilidade. ${ }^{*}=$ significativo pelo teste $\mathrm{F}$ a $5 \%$ de probabilidade. 


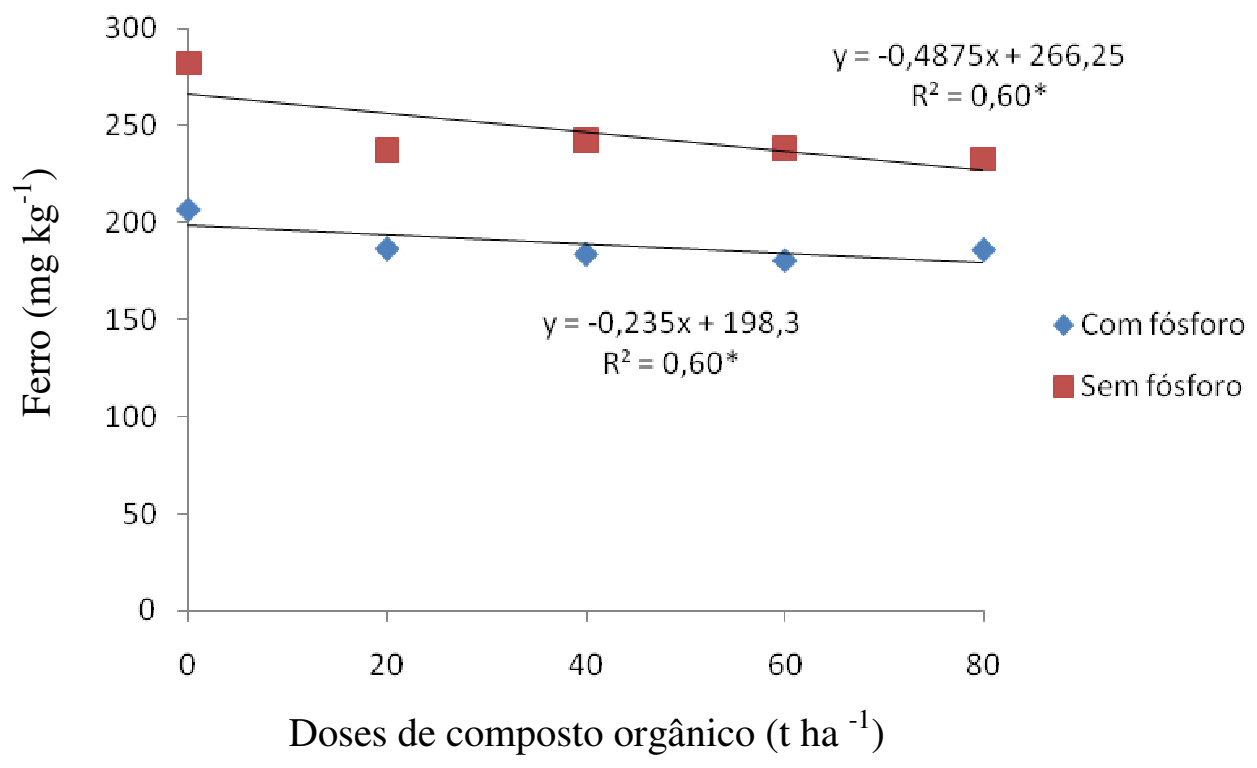

Figura 13. Teor de ferro nas sementes de alface em função das doses de composto orgânico com e sem aplicação de fósforo no solo. FCA/UNESP, São Manuel-SP, 2009.

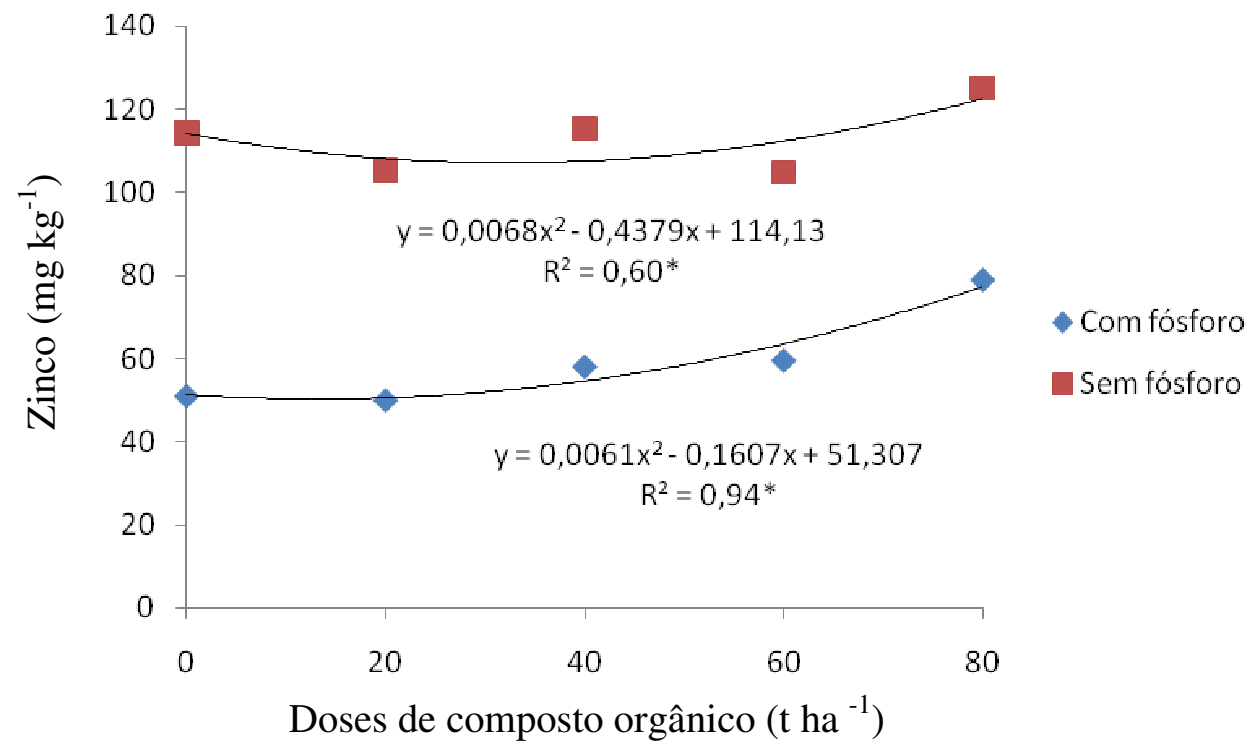

Figura 14. Teor de zinco nas sementes de alface em função das doses de composto orgânico com e sem aplicação de fósforo no solo. FCA/UNESP, São Manuel-SP, 2009. 


\subsection{Quantidade de nutrientes nas sementes}

\subsubsection{Quantidade de macronutrientes nas sementes}

Não houve interação significativa entre os fatores (composto orgânico e fósforo). Observou-se maior acúmulo de macronutrientes nas sementes de alface nos tratamentos com aplicação de fósforo (Tabela 9), provavelmente pela maior produção de sementes nestes tratamentos conforme será discutido posteriormente. A quantidade de nitrogênio é cerca de quatro vezes superior, fósforo seis vezes, potássio, cálcio e magnésio são cinco vezes e enxofre três vezes superior.

As doses de composto orgânico utilizadas não influenciaram nas quantidades de nitrogênio, fósforo, potássio, cálcio e enxofre encontrados nas sementes, no entanto, afetaram a quantidade de magnésio (Tabela 10). $\mathrm{O}$ acúmulo de magnésio ajustou-se ao modelo quadrático de regressão com máximo acúmulo estimado em 56,52 e 13,89 mg planta $^{-1}$ com as doses de 46,09 $\mathrm{t} \mathrm{ha}^{-1}$ de composto orgânico com fósforo e 44,28 $\mathrm{t} \mathrm{ha}^{-1}$ de composto orgânico sem fósforo (Figura 8).

A ordem decrescente média da quantidade dos macronutrientes acumulados nas sementes foi: nitrogênio $>$ fósforo $>$ potássio $>$ cálcio $>$ magnésio $>$ enxofre. Ressalta-se que essa ordem foi a mesma para todos os tratamentos avaliados. Kano (2006) ao avaliar doses de fósforo no acúmulo de macronutrientes pelas sementes de alface obteve a seguinte ordem: nitrogênio $>$ fósforo $>$ potássio $>$ magnésio $>$ cálcio $>$ enxofre, ou seja, muito semelhante a este trabalho, apenas com a inversão do cálcio com o magnésio. Magro et al. (2009) ao avaliarem doses de composto orgânico no acúmulo de macronutrientes pelas sementes de brócolis obtiveram a seguinte ordem: nitrogênio $>$ enxofre $>$ fósforo $>$ potássio $>$ cálcio > magnésio. Destaca-se como principal diferença entre as ordens, o enxofre como segundo nutriente mais acumulado pelas sementes de brócolis. Provavelmente este fato se deva a maior exigência desse nutriente para as brássicas, que retiram do solo quantidades mais substanciais de enxofre em relação a outros macronutrientes (FILGUEIRA, 2005). Assim, o enxofre nas sementes dessa brássica foi muito mais acumulado que nas sementes de alface.

$$
\text { O cálcio foi relativamente pouco acumulado nas sementes, }
$$
provavelmente, por ser um elemento pouco móvel dentro da planta e por ser mais exigido entre os demais nutrientes e, segundo Kano (2006), seu acúmulo na semente deve ter ocorrido 
apenas por absorção e transporte durante a maturação das sementes, sem redistribuição das folhas em senescência.

Tabela 9. Quantidade acumulada de nitrogênio, fósforo, potássio, cálcio, magnésio e enxofre (mg planta $^{-1}$ ) obtidos nas sementes de alface em função de tratamentos com e sem aplicação de fósforo. FCA/UNESP, São Manuel-SP, 2009.

\begin{tabular}{lcccccc}
\hline Tratamento & $\mathrm{N}$ & $\mathrm{P}$ & $\mathrm{K}$ & $\mathrm{Ca}$ & $\mathrm{Mg}$ & $\mathrm{S}$ \\
$\left(\mathrm{kg} \mathrm{ha}^{-1} \mathrm{P}_{2} \mathrm{O}_{5}\right)$ & - & & & \\
Com fósforo & $639,62 \mathrm{a}$ & $106,42 \mathrm{a}$ & $96,88 \mathrm{a}$ & $54,65 \mathrm{a}$ & $50,02 \mathrm{a}$ & $26,19 \mathrm{a}$ \\
Sem fósforo & $172,11 \mathrm{~b}$ & $18,62 \mathrm{~b}$ & $20,45 \mathrm{~b}$ & $11,63 \mathrm{~b}$ & $11,19 \mathrm{~b}$ & $9,13 \mathrm{~b}$ \\
\hline $\mathrm{CV}(\%)$ & 20,45 & 22,63 & 23,14 & 26,15 & 23,80 & 22,47 \\
\hline
\end{tabular}

$\mathrm{CV}=$ coeficiente de variação. Médias seguidas por mesma letras, nas colunas, não diferem entre si pelo teste de $\mathrm{F}$ a $5 \%$ de probabilidade.

Tabela 10. Quantidade acumulada de nitrogênio, fósforo, potássio, cálcio, magnésio e enxofre (mg planta $^{-1}$ ) obtidos nas sementes de alface, em função de doses de composto orgânico. FCA/UNESP, São Manuel-SP, 2009.

\begin{tabular}{|c|c|c|c|c|c|c|}
\hline \multirow{2}{*}{$\begin{array}{c}\text { Tratamento } \\
\text { (t ha }{ }^{-1} \text { de composto) }\end{array}$} & $\mathrm{N}$ & $\mathrm{P}$ & $\mathrm{K}$ & $\mathrm{Ca}$ & $\mathrm{Mg}^{*}$ & $\mathrm{~S}$ \\
\hline & \multicolumn{6}{|c|}{ 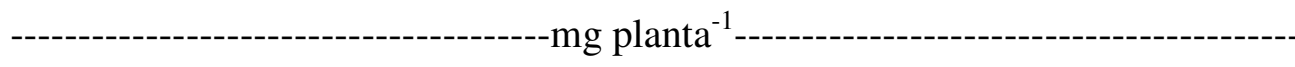 } \\
\hline T0 & $382,36 \mathrm{a}$ & $59,10 \mathrm{a}$ & $51,23 \mathrm{a}$ & $30,79 \mathrm{a}$ & 23,77 & $16,38 \mathrm{a}$ \\
\hline $\mathrm{T} 20$ & $415,64 \mathrm{a}$ & $61,39 \mathrm{a}$ & 57,14 a & 33,81 a & 31,12 & $18,43 \mathrm{a}$ \\
\hline $\mathrm{T} 40$ & 464,17 a & $71,55 \mathrm{a}$ & 65,93 a & $35,65 \mathrm{a}$ & 35,86 & $19,27 \mathrm{a}$ \\
\hline T60 & $422,23 \mathrm{a}$ & $63,82 \mathrm{a}$ & $61,37 \mathrm{a}$ & 36,18 a & 33,43 & $19,31 \mathrm{a}$ \\
\hline $\mathrm{T} 80$ & $344,93 \mathrm{a}$ & 56,76 a & $57,66 \mathrm{a}$ & $30,28 \mathrm{a}$ & 28,86 & $14,91 \mathrm{a}$ \\
\hline $\mathrm{CV}(\%)$ & 20,45 & 22,63 & 23,14 & 26,15 & 23,80 & 22,47 \\
\hline
\end{tabular}

$\mathrm{CV}=$ coeficiente de variação. Médias seguidas por mesma letra, nas colunas, não diferem entre si pelo teste de Tukey a $5 \%$ de probabilidade. ${ }^{*}=$ significativo pelo teste de $\mathrm{F}$ a $5 \%$ de probabilidade. 


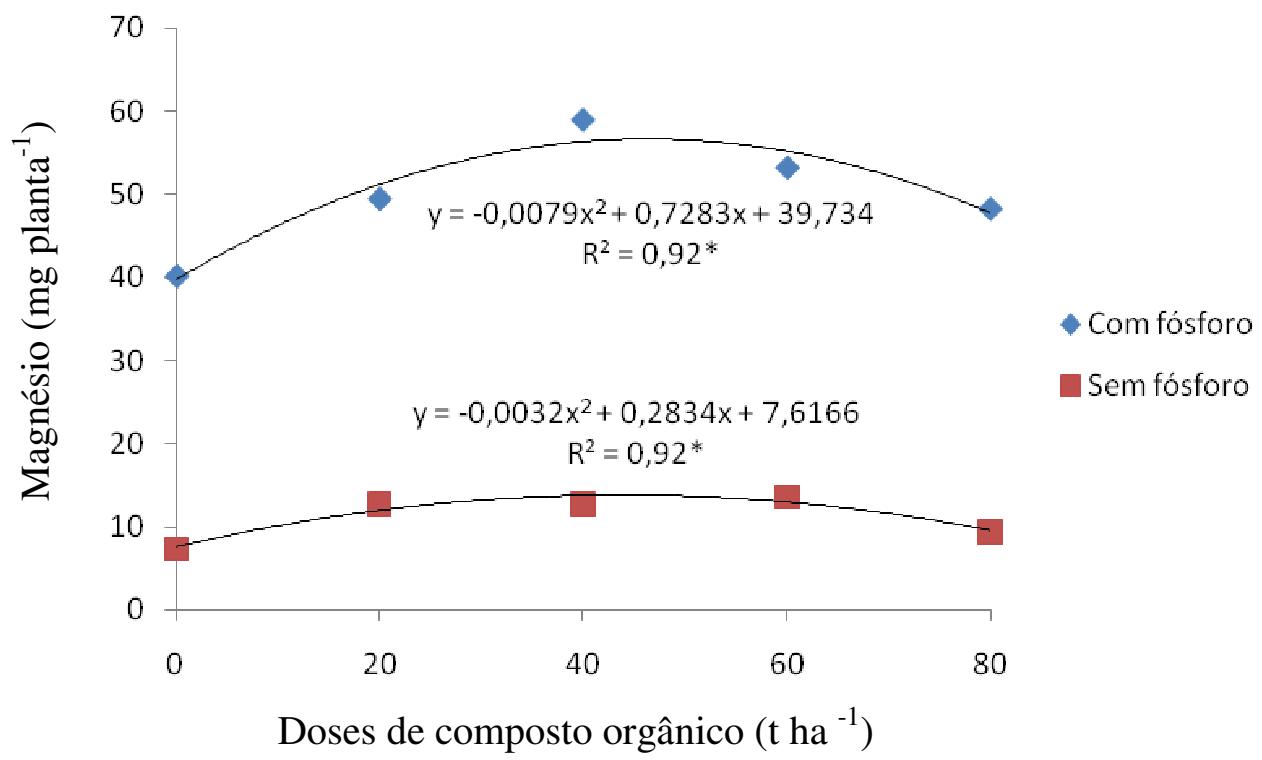

Figura 8. Quantidade acumulada de magnésio nas sementes de alface em função das doses de composto orgânico com e sem aplicação de fósforo no solo. FCA/UNESP, São Manuel-SP, 2009.

\subsubsection{Quantidade de micronutrientes nas sementes}

Não houve interação significativa entre os fatores (composto orgânico e fósforo). Observou-se maior acúmulo de micronutrientes nas sementes nos tratamentos com aplicação de fósforo (Tabela 11) provavelmente pela maior produção de sementes nestes tratamentos conforme será discutido posteriormente. A quantidade de cobre e zinco são duas vezes superiores e boro, ferro e manganês são cerca de quatro vezes superiores.

As doses de composto orgânico utilizadas não influenciaram as quantidades de boro, cobre, ferro e manganês encontrados nas sementes, no entanto, afetaram a quantidade de zinco (Tabela 12).

O acúmulo de zinco ajustou-se ao modelo quadrático de regressão com máximo acúmulo estimado em 0,95 e $0,50 \mathrm{mg}_{\text {planta }}{ }^{-1}$ com as doses de $80 \mathrm{t} \mathrm{ha}^{-1}$ de composto orgânico com fósforo e 48,33 $\mathrm{t} \mathrm{ha}^{-1}$ de composto orgânico sem fósforo (Figura 9).

A ordem decrescente média da quantidade dos micronutrientes acumulados nas sementes foi: ferro $>$ manganês $>$ zinco $>$ boro $>$ cobre. Ressalta-se que essa ordem foi a mesma para todos os tratamentos avaliados. Kano (2006) ao avaliar doses de fósforo no acúmulo de micronutrientes pelas sementes de alface obteve a seguinte ordem: 
ferro $>$ zinco $>$ manganês $>$ cobre $>$ boro. As diferenças entre ambas as ordens foram inversões no acúmulo entre manganês e zinco e entre boro e cobre, provavelmente por diferenças na quantidade destes nutrientes disponíveis nos solos utilizados e pela ausência de adubação de cobertura neste experimento. Magro et al. (2009) ao avaliarem doses de composto orgânico no acúmulo de micronutrientes pelas sementes de brócolis obtiveram a seguinte ordem: ferro $>$ zinco $>$ manganês $>$ boro $>$ cobre.

Tabela 11. Quantidade acumulada de boro, cobre, ferro, manganês e zinco (mg planta ${ }^{-1}$ ) obtidos nas sementes de alface em função de tratamentos com e sem aplicação de fósforo. FCA/UNESP, São Manuel-SP, 2009.

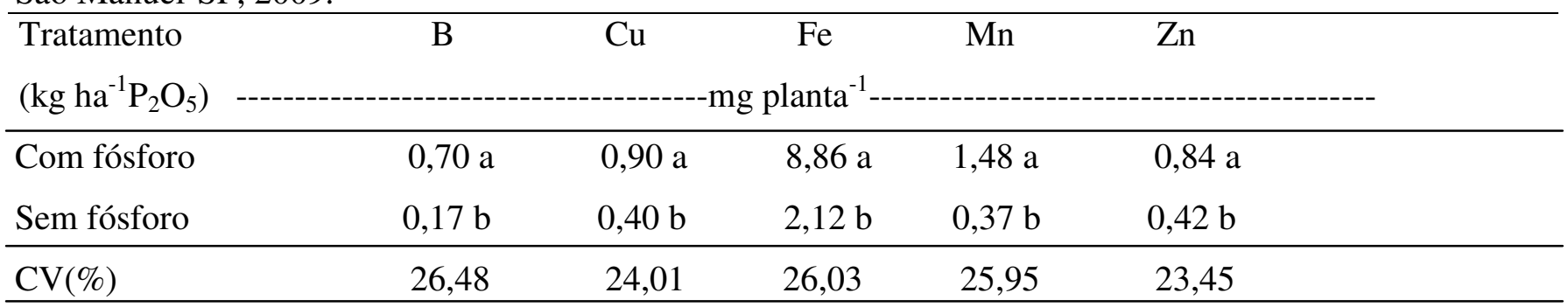

$\mathrm{CV}=$ coeficiente de variação. Médias seguidas por mesma letra, nas colunas, não diferem entre si pelo teste $\mathrm{F}$ a $5 \%$ de probabilidade.

Tabela 12. Quantidade acumulada de boro, cobre, ferro, manganês e zinco (mg planta $\left.{ }^{-1}\right)$ obtidos nas sementes de alface em função de doses de composto orgânico. FCA/UNESP, São Manuel-SP, 2009.

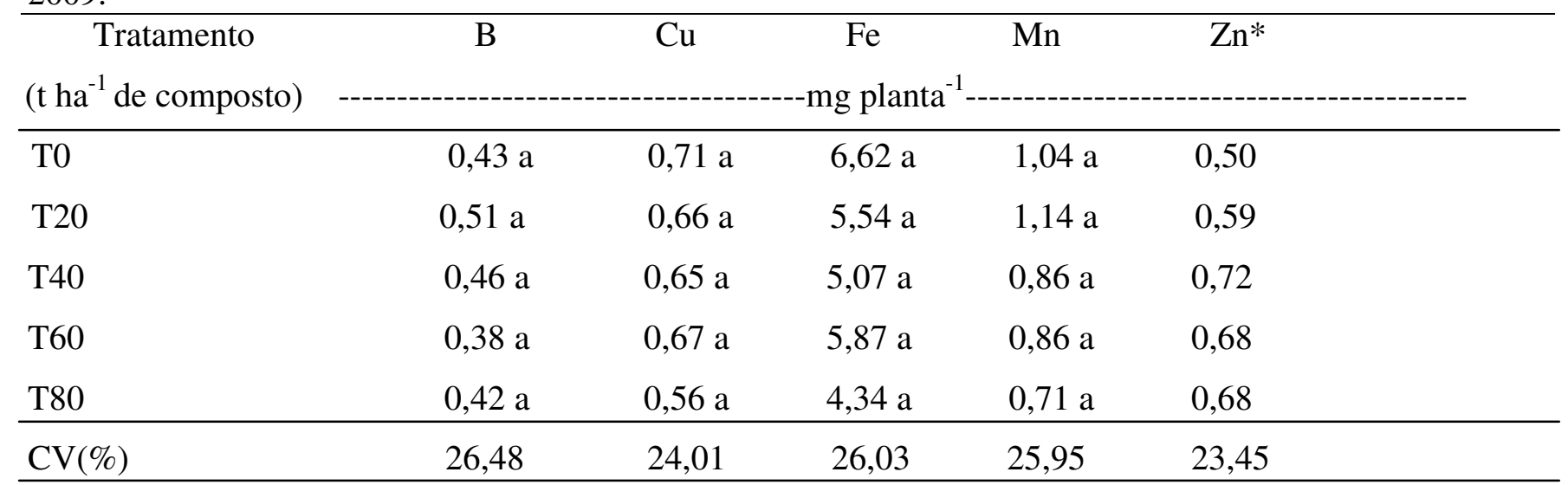

$\mathrm{CV}=$ coeficiente de variação. Médias seguidas por mesma letra, nas colunas, não diferem entre si pelo teste de Tukey a $5 \%$ de probabilidade. ${ }^{*}=$ significativo pelo teste $\mathrm{F}$ a $5 \%$ de probabilidade. 


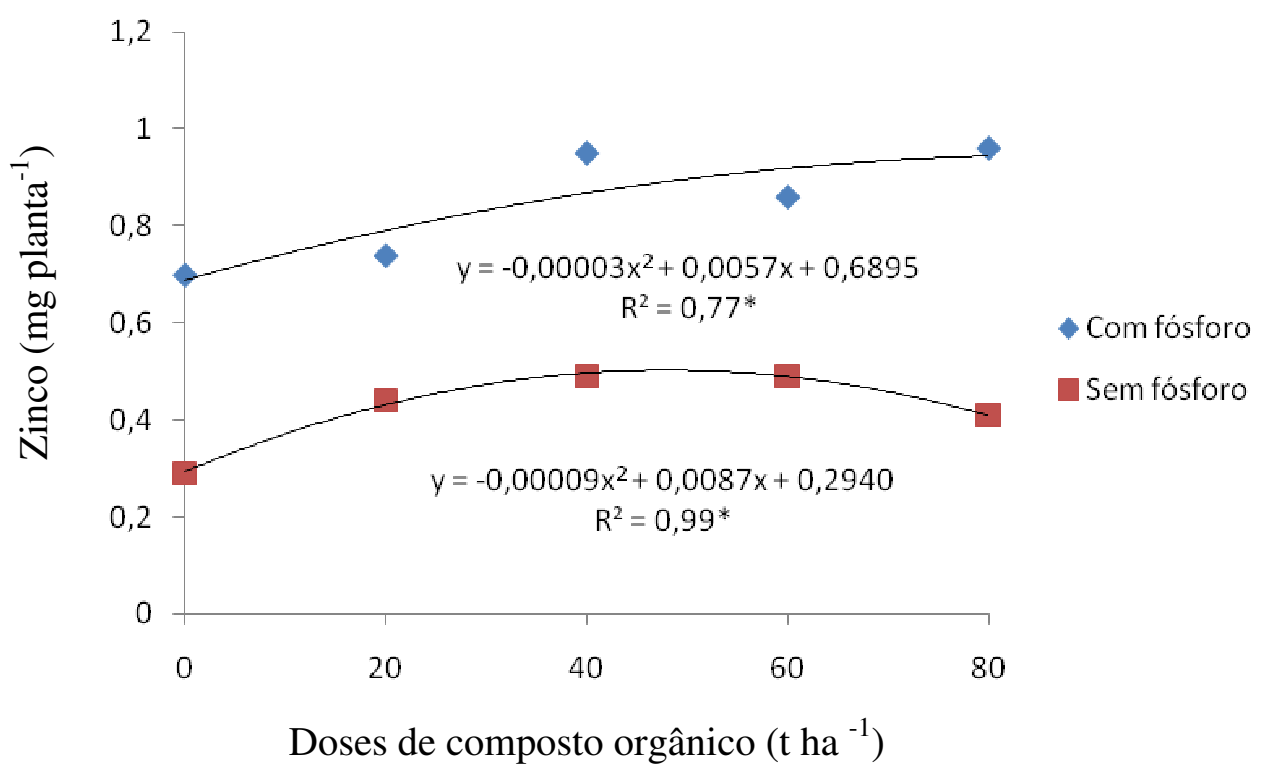

Figura 9. Quantidade acumulada de zinco nas sementes de alface em função das doses de composto orgânico com e sem aplicação de fósforo no solo. FCA/UNESP, São ManuelSP, 2009.

\subsection{Produção de sementes}

Não houve interação significativa entre os fatores (composto orgânico e fósforo). As médias de produção de sementes, tanto de massa como em número por planta, apresentaram tendências parecidas e ajustaram-se ao modelo quadrático de regressão. A dose de 33,43 $\mathrm{t} \mathrm{ha}^{-1}$ de composto orgânico com fósforo e 49,21 $\mathrm{t} \mathrm{ha}^{-1}$ de composto orgânico sem fósforo apresentaram maiores massas de sementes (17,14 e 4,8 $\mathrm{g} \mathrm{planta}^{-1}$, respectivamente) (Figura 15). Já a dose de 20,19 $\mathrm{t} \mathrm{ha}^{-1}$ de composto orgânico com fósforo e 43,39 $\mathrm{t} \mathrm{ha}^{-1}$ de composto orgânico sem fósforo apresentaram maiores número de sementes (15917 e 4190 planta $^{-1}$ ), respectivamente (Figura 16).

Pôde-se observar neste experimento que a presença de fósforo aliada ao composto orgânico apresentou um incremento de $12,34 \mathrm{~g} \mathrm{planta}^{-1}$ a mais na massa de sementes e 11726 sementes planta $^{-1}$ a mais, comparativamente aos tratamentos com doses de composto orgânico sem fósforo. Além disto, demandaram 15,78 $\mathrm{t} \mathrm{ha}^{-1}$ e 23,20 t ha ${ }^{-1}$ a menos de composto para se obter a produção máxima em massa e número de sementes, respectivamente, além de apresentar os maiores $\mathrm{R}^{2}$. 
Ressalta-se que no início da fase reprodutiva, a exigência nutricional para a maioria das espécies torna-se mais intensa, sendo mais crítica na formação das sementes, quando considerável quantidade de nutrientes, como o fósforo, o nitrogênio e o potássio, são para elas translocadas (CARVALHO \& NAKAGAWA, 2000). Assim, pode-se concluir que a presença de fósforo foi determinante para uma maior produção de sementes, entretanto a adubação com composto orgânico, que apresenta lenta liberação de nutrientes para a planta, também teve efeito positivo nesta etapa.

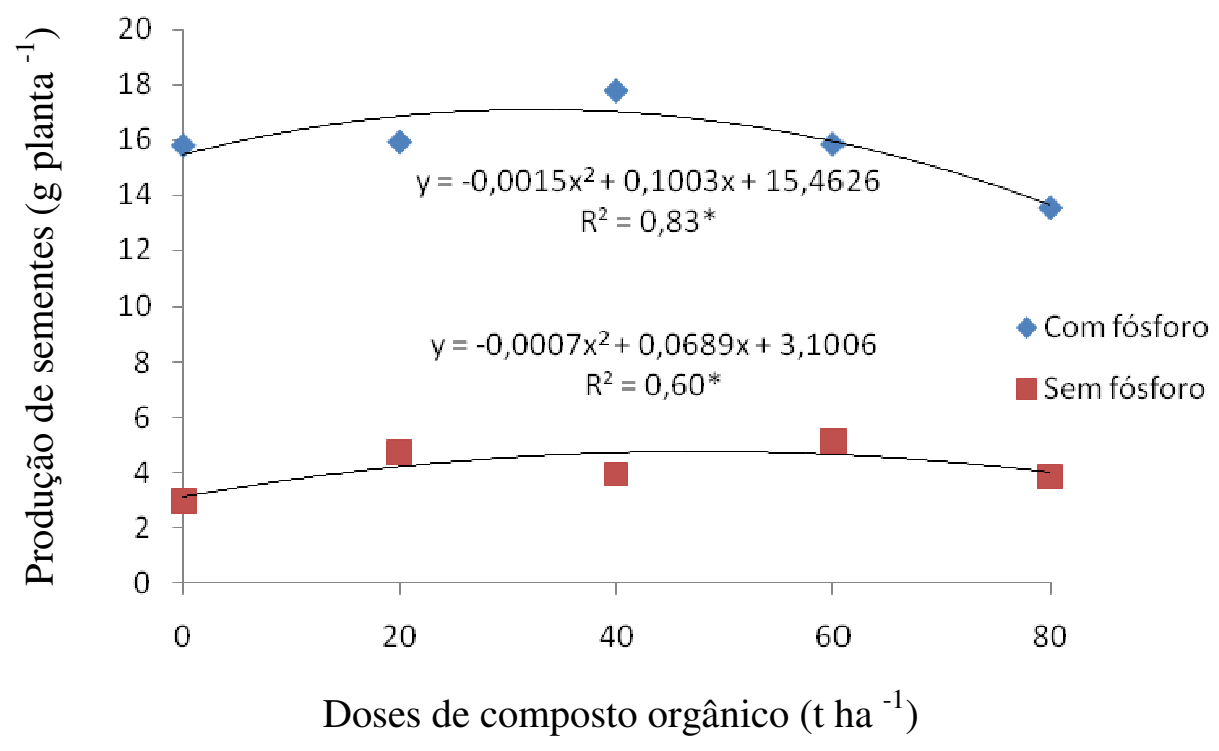

Figura 15. Produção de sementes de alface cv. Verônica em função de doses de composto orgânico, com e sem fósforo aplicados no solo. FCA/ UNESP, São Manuel-SP, 2009. 


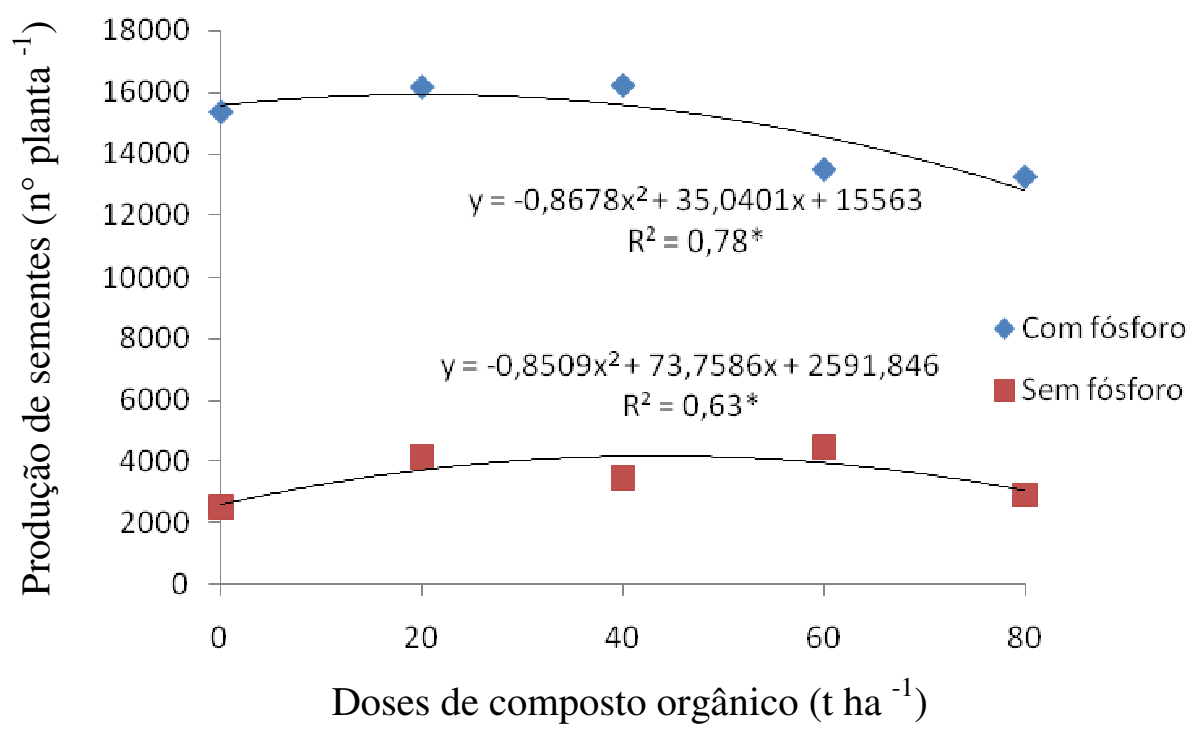

Figura 16. Número de sementes produzidas por planta de alface cv. Verônica em função das doses de composto orgânico, com e sem fósforo aplicados no solo. FCA/UNESP, São ManuelSP, 2009.

Os valores obtidos na ausência de fósforo (2,97 a 5,13 $\left.\mathrm{g} \mathrm{planta}^{-1}\right)$ estiveram próximos do relatado por Viggiano (1990) para a cultivar de verão Regina (3,86 g planta $^{-1}$ ), por Globerson \& Ventura (1973), 2,4 g planta ${ }^{-1}$ e por Izzeldin et al. (1980) de 3,7 a $10,5 \mathrm{~g} \mathrm{planta}^{-1}$. Já na presença de fósforo, as médias (13,56 a 17,77 $\left.\mathrm{g} \mathrm{planta}^{-1}\right)$ foram semelhantes aos relatados por Kano et al. (2006) para a cultivar Verônica (17 $\mathrm{g} \mathrm{planta}^{-1}$ ), Reghin et al. (2000), cerca de 18 g planta $^{-1}$, Aguiar (1982), Soffer \& Smith (1974a e 1974b) que obtiveram média de $17,9 \mathrm{~g}$ planta $^{-1}$ e $15,8 \mathrm{~g} \mathrm{planta}^{-1}$, respectivamente. Estas variações podem estar relacionadas a diferenças de cultivares, condições climáticas e de manejo, mas mostram claramente a importância do fósforo para a produção de sementes nesta cultura.

\subsection{Qualidade de sementes}

Quanto à qualidade das sementes, não houve efeito significativo de doses de composto orgânico e nem de fósforo para todas as características avaliadas: massa de mil sementes, primeira contagem de germinação, teste padrão de germinação, índice de velocidade de germinação, índice de velocidade de emergência das plântulas, percentual de plântulas emergidas em bandeja e teste de condutividade elétrica (Tabelas 21 e 22), demonstrando que a qualidade das sementes não foi influenciada pelas doses de composto 
orgânico, com e sem fósforo, adicionadas ao solo. Ressalta-se que as sementes de todas as parcelas foram beneficiadas e os testes foram realizados nas sementes consideradas comerciais.

Para a massa de mil sementes, obteve-se uma média de $1,15 \mathrm{~g}$ (Tabelas 21 e 22), valor superior ao relatado por Viggiano (1990), que cita a média de 0,8 g, por Reghin et al. (2000), que foi de 1,0 g, por Kano et al. (2006), de 1,06g, também para a cultivar Verônica e ao valor médio relatado por George (1999), que varia de 0,6 a 1,0 g, dependendo da cultivar de alface.

A geminação e a emergência de plântulas final foram elevadas $(\geq 84 \%$ e $\geq 93 \%$, respectivamente) (Tabelas 21 e 22). Porém, o vigor das sementes testadas foi baixo, pois na primeira contagem, observou-se 13 sementes germinadas em todos os tratamentos. $\mathrm{O}$ IVG foi $\geq 15,67$, inferior ao relatado por Kano (2006) que foi $\geq 66,50$ e por Kano et al. (2006), que foi $\geq 27,3$. Esse baixo vigor e IVG podem ter ocorrido em função das sementes terem sido consideradas como germinadas a partir do aparecimento das folhas cotiledonares e não a partir da radícula, como mostra a figura 17.

O baixo vigor das sementes também pode ser percebido no IVE $(\geq$ 18,31), inferior ao obtido por Kano (2006), que foi $\geq 95,70$ e por Kano et al. (2006) que foi $\geq$ 32,5 . 


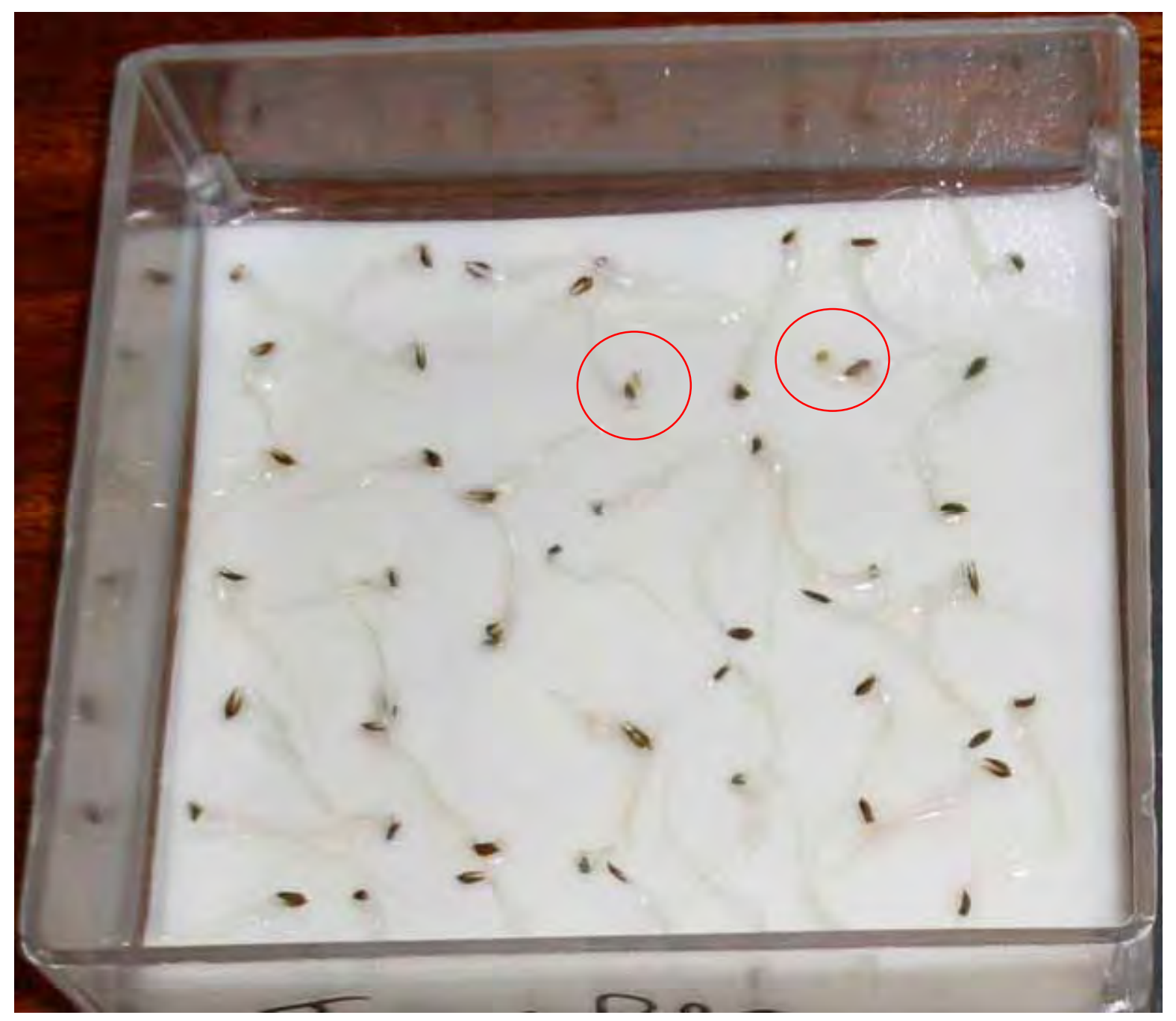

Figura 17. Sementes de alface cv. 'Verônica' em estádio considerado como germinada.

A influência da adubação na produção e não na qualidade de sementes de alface também foi verificada por Kano et al. (2006) e Kano (2006) que observaram que doses crescentes de $\mathrm{K}_{2} \mathrm{O}$ e $\mathrm{P}_{2} \mathrm{O}_{5}$, respectivamente, não afetaram a qualidade das sementes de alface dessa mesma cultivar avaliada. Também Soffer \& Smith (1974a) verificaram que o aumento no nível de fertilidade do solo aumentou a produção de sementes, porém, não ocasionou aumento correspondente no vigor.

O valor médio de condutividade elétrica foi de $111,51 \mu \mathrm{S} / \mathrm{cm} / \mathrm{g}$ sementes com 6 horas de embebição (Tabelas 21 e 22), valor acima do relatado por Franzin et al. (2004), de $71 \mu \mathrm{S} / \mathrm{cm} / \mathrm{g}$ sementes. O teste de condutividade elétrica avalia indiretamente a 
concentração de eletrólitos liberados pelas sementes durante a embebição, fornecendo resultados em curto prazo, sendo, portanto, um teste rápido. Baixos valores de condutividade indicam baixa lixiviação, podendo-se afirmar que as sementes apresentam alta qualidade, ao passo que valores elevados estão relacionados a sementes de qualidade inferior. Neste experimento, o elevado valor para a condutividade elétrica pode estar vinculado à deficiência na constituição das membranas dos tecidos da semente, confirmando o seu baixo vigor. Segundo Sá (1994), o aspecto nutricional das plantas afeta o vigor das sementes, sendo que em muitos casos estes efeitos estão ligados à permeabilidade e integridade das membranas dos tecidos, onde os nutrientes atuam como ativadores enzimáticos ou constituem essas membranas.

Tabela 21. Médias de massa de mil sementes, primeira contagem, germinação, Índice de velocidade de germinação, Índice de velocidade de emergência, percentual de plântulas emergidas e condutividade elétrica dos tratamentos com e sem aplicação de fósforo. FCA/UNESP, BotucatuSP, 2009.

\begin{tabular}{|c|c|c|c|c|c|c|c|}
\hline $\begin{array}{l}\text { Tratamento } \\
\left(\mathrm{Kg} \mathrm{ha}^{-1}\right. \\
\left.\mathrm{P}_{2} \mathrm{O}_{5}\right)\end{array}$ & $\begin{array}{l}\text { Massa de } \\
\text { mil } \\
\text { sementes (g) }\end{array}$ & $\begin{array}{r}\text { Teste pac } \\
\text { germinaçã } \\
1{ }^{\mathrm{a}} \text { Contagem }\end{array}$ & $\begin{array}{l}\text { drão de } \\
\text { io }\left(20^{\circ} \mathrm{C}\right) \\
\text { Germinação }\end{array}$ & IVG & IVE & $\begin{array}{c}\text { \% de } \\
\text { plântulas } \\
\text { emergidas }\end{array}$ & $\begin{array}{l}\text { Condutividade } \\
\text { elétrica } \\
(\mu \mathrm{S} / \mathrm{cm} / \mathrm{g} \text { sementes })\end{array}$ \\
\hline Com fósforo & $1,14 \mathrm{a}$ & $13 \mathrm{a}$ & $91 \mathrm{a}$ & $17,25 \mathrm{a}$ & $19,12 \mathrm{a}$ & $95 \mathrm{a}$ & $109,80 \mathrm{a}$ \\
\hline Sem fósforo & $1,15 \mathrm{a}$ & $13 \mathrm{a}$ & $87 \mathrm{a}$ & $16,56 \mathrm{a}$ & $18,83 \mathrm{a}$ & $94 \mathrm{a}$ & $113,22 \mathrm{a}$ \\
\hline $\mathrm{CV}(\%)$ & 5,97 & 17,56 & 12,62 & 12,68 & 5,16 & 6,64 & 22,55 \\
\hline
\end{tabular}

IVE = índice de velocidade de emergência; IVG = índice de velocidade de germinação; CV = coeficiente de variação. Médias seguidas por mesma letra, nas colunas, não diferem entre si pelo teste $\mathrm{F}$ a $5 \%$ de probabilidade. 
Tabela 22. Médias de massa de mil sementes, primeira contagem, germinação, Índice de velocidade de germinação, Índice de velocidade de emergência, percentual de plântulas emergidas e condutividade elétrica das sementes de alface em função da aplicação de doses de composto orgânico. FCA/UNESP, Botucatu-SP, 2009.

\begin{tabular}{|c|c|c|c|c|c|c|c|}
\hline $\begin{array}{l}\text { Tratamento } \\
\left(\mathrm{t} \mathrm{ha}^{-1} \mathrm{de}\right. \\
\text { composto) }\end{array}$ & $\begin{array}{c}\text { Massa de } \\
\text { mil } \\
\text { sementes (g) }\end{array}$ & $\begin{array}{r}\text { Teste pad } \\
\text { germinaçã } \\
1{ }^{a} \text { Contagem }\end{array}$ & $\begin{array}{l}\text { rão de } \\
\text { o }\left(20^{\circ} \mathrm{C}\right) \\
\text { Germinação }\end{array}$ & IVG & IVE & $\begin{array}{l}\text { \% de } \\
\text { plântulas } \\
\text { emergidas }\end{array}$ & $\begin{array}{l}\text { Condutividade } \\
\text { elétrica } \\
(\mu \mathrm{S} / \mathrm{cm} / \mathrm{g} \text { sementes })\end{array}$ \\
\hline T0 & $1,14 \mathrm{a}$ & $13 \mathrm{a}$ & $86 a$ & $16,95 \mathrm{a}$ & $18,31 \mathrm{a}$ & $93 a$ & $105,53 \mathrm{a}$ \\
\hline $\mathrm{T} 20$ & $1,14 \mathrm{a}$ & $13 \mathrm{a}$ & $84 \mathrm{a}$ & $15,67 \mathrm{a}$ & $18,96 \mathrm{a}$ & $94 \mathrm{a}$ & $116,75 \mathrm{a}$ \\
\hline $\mathrm{T} 40$ & $1,15 \mathrm{a}$ & $13 \mathrm{a}$ & $92 \mathrm{a}$ & $17,58 \mathrm{a}$ & $19,38 \mathrm{a}$ & $97 \mathrm{a}$ & $109,26 \mathrm{a}$ \\
\hline T60 & $1,15 \mathrm{a}$ & $13 \mathrm{a}$ & $89 \mathrm{a}$ & $15,90 \mathrm{a}$ & 19,09 a & $93 \mathrm{a}$ & $116,75 \mathrm{a}$ \\
\hline $\mathrm{T} 80$ & $1,15 \mathrm{a}$ & $13 \mathrm{a}$ & $94 \mathrm{a}$ & $18,43 \mathrm{a}$ & $19,16 \mathrm{a}$ & $94 \mathrm{a}$ & $109,07 \mathrm{a}$ \\
\hline $\mathrm{CV}(\%)$ & 5,97 & 17,57 & 12,62 & 12,68 & 5,16 & 6,64 & 22,55 \\
\hline
\end{tabular}

IVE = índice de velocidade de emergência; IVG = índice de velocidade de germinação; $\mathrm{CV}=$ coeficiente de variação. Médias seguidas por mesma letra, nas colunas, não diferem entre si pelo teste de Tukey a $5 \%$ de probabilidade.

Harrington (1960), ao cultivar plantas de alface, cenoura e pimenta em solução completa de nutrientes e sob deficiência de nitrogênio, fósforo, potássio e cálcio, verificou que a produção de sementes foi reduzida nos tratamentos com deficiência desses nutrientes. Já a porcentagem de sementes normais foi reduzida nos tratamentos com deficiência de nitrogênio, potássio e cálcio, porém não no tratamento com deficiência de fósforo.

Para couve-flor, em que também ocorre aumento do ciclo com o estádio reprodutivo, Jana \& Mukhopadhyay (2002) verificaram aumento na massa de mil sementes e na porcentagem de germinação com o aumento das doses de fósforo.

$\mathrm{Na}$ literatura consultada, não foram encontrados trabalhos relacionando adubação orgânica com qualidade fisiológica de sementes de alface. Em brócolis, Magro (2009) não observou efeito de doses de composto orgânico sob a qualidade fisiológica de sementes. Bruno et al. (2007), ao avaliarem a qualidade fisiológica de sementes de cenoura sob diferentes fontes de adubação, verificaram que o composto orgânico na presença de biofertilizante resultou em sementes mais vigorosas comparadas à testemunha sem composto. Já em coentro, Alves et al. (2005) obtiveram aumento na produção de sementes em função das 
doses de esterco bovino e verificaram que a germinação e o índice de velocidade de germinação aumentaram linearmente com a elevação das doses de matéria orgânica.

Neste trabalho usou-se sementes beneficiadas o que justifica a boa germinação e emergência. Quanto aos trabalhos citados nem sempre há descrição na metodologia sobre o uso ou não de sementes beneficiadas, o que dificulta a comparação. 


\subsection{CONSIDERAÇÕES GERAIS}

É importante salientar algumas dificuldades ocorridas durante a execução do experimento que podem, ou não, ter influenciado de alguma maneira em alguns resultados.

Ao comparar os teores obtidos na parte aérea das plantas para a produção de sementes com os apresentados por Raij et al. (1997) nas folhas de alface para o consumo, ou seja, em máximo vigor vegetativo e antes de atingir seu estádio reprodutivo, observou-se que os teores obtidos foram inferiores para a maioria dos nutrientes. Vale ressaltar que o ciclo para a produção de sementes é aumentado e que alguns teores foram bem abaixo àqueles encontrados em alface para o consumo de folhas. É provável que isto tenha ocorrido em função da translocação dos nutrientes da planta e da ausência de adubação de cobertura durante a condução do experimento, onde somente as doses de composto orgânico utilizadas como tratamento talvez não tenham sido suficientes para o suprimento destes nutrientes para as plantas de alface.

$\mathrm{Na}$ coleta de plantas para avaliação de massa fresca e massa seca, como as mesmas já se encontravam no final do ciclo, muitas delas já nem apresentavam folhas o que possivelmente provocou uma variação considerável na estatística dos dados obtidos, inviabilizando o fornecimento de resultados consistentes sobre o acúmulo de nutrientes no caule + folhas + hastes florais, bem como na parte aérea total das plantas.

Mesmo com as dificuldades aqui mencionadas, a presença de fósforo aliada as doses de composto orgânico avaliadas foram fundamentais para promover o aumento na produção de sementes pela planta (tanto em massa como em número). Novos experimentos podem ser feitos visando o aprimoramento da adubação orgânica e fosfatada, visto que é uma técnica que carece de estudos específicos, principalmente no que diz respeito a produção e qualidade de sementes.

A execução desses trabalhos pode ser direcionada a avaliar tipos e doses de adubação fosfatada, também podem ser direcionadas ao estudo das propriedades da matéria orgânica, como sua velocidade de degradação e liberação efetiva de nutrientes ou efeito residual em ciclos posteriores. Também podem ser feitos trabalhos que aprofundem em relação à extração de nutrientes pela cultura, como por exemplo, a marcha de absorção de nutrientes pela planta. 


\section{CONCLUSÕES}

\section{Conclui-se que:}

$\checkmark$ A aplicação de fósforo aumentou a produção de sementes.

$\checkmark$ O composto orgânico sem adição de fósforo ao solo não afetou a produção de sementes e nos tratamentos de composto orgânico com adição de fósforo ao solo afetou-se a produção de sementes.

$\checkmark$ A qualidade das sementes não foi afetada tanto pela adubação com composto orgânico como com fósforo. 


\section{REFERÊNCIAS BIBLIOGRÁFICAS}

AGUIAR, P.A.A. Influência do ácido giberélico na produção de sementes de alface. Revista Brasileira de Sementes, Brasília, v.4, n.1, p.89-95, 1982.

ALLISON, F.E. Soil organic matter and its role in crop production. London: Elsevier Scientific Publishing Co., 1973. 637p.

ALVES, E.U.; OLIVEIRA, A.P.; BRUNO, R.L.A.; SADER, R.; ALVES, A.U. Rendimento e qualidade fisiológica de sementes de coentro cultivado com adubação orgânica e mineral.

Revista Brasileira de Sementes, Brasília, v.27, n.1, p. 132-137, 2005.

ARRUDA JÚNIOR, S.J.; MELO, E.E.C.; SILVA, M.O.; SOUSA, C.E.S.; FREIRE, M.B.G.S. Produtividade e teor de P de plantas de alface em função de diferentes doses de fósforo no solo. In: CONGRESSO BRASILEIRO DE OLERICULTURA, 45., 2005 , Fortaleza. Anais... Fortaleza, 2005. 1 CD-ROM.

BEBÉ, F.V.; MATSUMOTO, S.N.; FONTES, P.C.R.; MOREIRA, M.A.; PIMENTEL, C.A.S.; RIBEIRO, M.S.; CRUZ, D.S.; FERRAZ, R.C.N. Crescimento e produtividade de alface influenciados pela aplicação de fósforo no solo e de zinco via foliar. In: CONGRESSO BRASILEIRO DE OLERICULTURA, 45., 2005, Fortaleza. Anais... Fortaleza, 2005. 1 CDROM.

BENINNI, E.R.Y. Concentração e acúmulo de macronutrientes em alface cultivada em sistemas hidropônicos e convencional. 2002. 33f. Dissertação (Mestrado em Agronomia) Universidade Estadual de Londrina, Londrina, 2002.

BISCARO, G. A.; BATISTA, M. F.; KOYANAGUI, M. T.; FERNANDES, P.; ZONTA, T. T.; OLIVEIRA, A. C. DE; MAIA, S. C. M.; MARUYAMA, W. I. Avaliação da adubação fosfatada no desenvolvimento da alface 'Verônica' nas condições de Cassilândia-MS. Disponível em: <http://www.google.com.br>. Acesso em: 28 set. 2009.

BRASIL. Ministério da Agricultura e Reforma Agrária. Regras para análise de sementes. Brasília: SNDA/DNDV/CLAV, 1992. 365p.

BRUNO, R.L.A.; VIANA, J.S.; SILVA, V.F.; BRUNO, G.B.; MOURA, M.F. Produção e qualidade de sementes e raízes de cenoura cultivada em solo com adubação orgânica e mineral. Horticultura Brasileira, Brasília, v.25, p.170-174, 2007.

CARVALHO, N.M.; NAKAGAWA, J. Sementes: ciência, tecnologia e produção. 4.ed. Jaboticabal: FUNEP, 2000. 588p.

CARVALHO, J.L. Efeito da adubação nitrogenada sobre a produção e qualidade de sementes de alface (Lactuca sativa L.). 1978. 54f. Dissertação (Mestrado em Agronomia/Fitotecnia) - Escola Superior de Agricultura Luiz de Queiroz, Universidade de São Paulo, Piracicaba, 1978. 
CLAASSENS, A.S. Influence of varying phosphorus supply on the growth and phosphorus composition of lettuce. Communication in Soil Science and Plant Analysis, New York, v.25, n.9-10, p.1209-1221, 1994.

COPELAND, L.O.; McDONALD, M.B. Principles of seed science and technology. 3.ed. New York: Chapman \& Hall, 1995. 409p.

DELOUCHE, J.C. Environmental effects on seed developytment and seed quality. HortScience, Alexandria, v.15, n.6, p.775-780, 1980.

DINIZ, E.R.; SANTOS, R.H.S.; URQUIAGA, S.S.; PETERNELLI, L.A.; BARRELLA, T.P.; FREITAS, G.B. Crescimento e produção de brócolis em sistema orgânico em função de doses de composto. Ciência e Agrotecnologia, Lavras, v.32, n.5, p.1428-1434, 2008.

EMPRESA BRASILEIRA DE PESQUISA AGROPECUÁRIA. Sistema brasileiro de classificação dos solos. Brasília: EMBRAPA, 1999. 412p.

ESPINDOLA, C.R.; TOSIN, W.A.C.; PACCOLA, A.A. Levantamento pedológico da Fazenda Experimental São Manuel. In: CONGRESSO BRASILEIRO DE CIÊNCIA DO SOLO, 14, 1974, Santa Maria. Anais... Santa Maria: Sociedade Brasileira de Ciência do Solo, 1974. p.650-654.

FILGUEIRA, F.A.R. Novo manual de olericultura: agrotecnologia moderna na produção e comercialização de hortaliças. Viçosa: UFV, 2005. 412p.

FRANZIN, S.M.; MENEZES, N.L.; GARCIA, D.C.; WRASSE, C.F. Métodos para avaliação do potencial fisiológico de sementes de alface. Revista Brasileira de Sementes, Brasília, v.26, n.2, p.63-69, 2004.

FONTANETTI, A.; ALMEIDA, K.; SOUZA, A.V.; CARVALHO, G.J. Adubação orgânica e química com e sem aplicação de resíduo siderúrgico, na produção de alface americana. In: CONGRESSO BRASILEIRO DE OLERICULTURA, 42., 2002, Uberlândia. Anais...

Uberlânida, 2002. 1 CD-ROM.

FORNASIERI FILHO, D.; BRANDÃO, S.S.; SADER, R.; VITTI, G.C. Efeitos do fósforo e do zinco sobre a composição mineral e qualidade fisiológica das sementes de milho- pipoca. Revista Brasileira de Sementes, Brasília, n.1, p.43-53, 1988.

GARCIA, L.L.C.; HAAG, H.P.; MINAMI, K.; DECHEN, A.R. Nutrição mineral de hortaliças. XLIX. Concentração e acúmulo de macronutrientes em alface (Lactuca sativa L.) cv. Brasil 48 e Clause's Aurélia. Anais da ESALQ, Piracicaba, v.39, p.455-484, 1982.

GEORGE, R.A.T. Vegetable seed production. 2.ed. Italy: Cabi Publishing, 1999. 328p.

GLOBERSON, D.; VENTURA, J. Influence of gibberelins on promoting flowering and seed 
yield in bolting resistant lettuce cultivars. Israel Journal Agricultural Research, Bet-Dagan, v.23, n.2, p.75-77, 1973.

GRAY, D.; WURR, D.C.E.; WARD, J.A.; FELLOWS, J.R. Influence of post-flowering temperature on seed development, and subsequent performance of crisp lettuce. Annals of Applied Biology, Warwick, v.113, p.391-402, 1988.

HARRINGTON, J.F. Germination of seeds from carrot, lettuce, and pepper plants grown under severe nutrient deficiencies. Journal of the American Society for Horticultural Science, Alexandria, v.30, n.7, p.219-235, 1960.

IZZELDIN, H.; LIPPERT, L.F.; TAKATORI, F.H. An influence of water stress at different growth stages on yield and quality of lettuce seed. Journal of The American Society for Horticultural Science, Alexandria, v.105, n.1, p.68-71, 1980.

JANA, J.C.; MUKHOPADHYAY, T.P. Effect of nitrogen and phosphorus on seed production of cauliflower var. Aghani in Terai zone of West Bengal. Seed Research, New Delhi, v.30, n.2, p.253-257, 2002.

KANO, C. Doses de fósforo no acúmulo de nutrientes, na produção e na qualidade desementes de alface. 2006. 112f. Tese (Doutorado em Agronomia/ Horticultura) Faculdade de Ciências Agronômicas, Universidade Estadual Paulista, Botucatu, 2006.

KANO, C.; CARDOSO, A.I.I.; HIGUTI, A.R.O.; VILLAS BÔAS, R.L. Doses de potássio na produção e qualidade de sementes de alface. Horticultura Brasileira, Brasília, v.24, n.3, p.356-359, 2006.

KIEHL, E.J. Fertilizantes orgânicos. São Paulo: Agronômica Ceres, 1985. 492p.

LIMA, M.S.; CARDOSO, A.I.I.; VERDIAL, M.F. Plant spacing and pollen quantity on yied and quality of squash seed. Horticultura Brasileira, Brasília, v.21, n.3, p.443-447, 2003.

LOPES, J.C.; RIBEIRO, L.G.; ARAÚJO, M.G.; BERALDO, M.R.B.S. Produção de alface com doses de lodo de esgoto. Horticultura Brasileira, Brasília, v.23, n.1, p.143-147, 2005.

LOTT, J.N.A.; GREENWOOD, J.S.; BATTEN, G.D. Mechanisms and regulation of mineral nutrient storage during seed development. In: KIGEL, J.; GALILI, G. Seed development and germination. New York: Marcel Dekker, 1995. p.215-235.

MAGRO, F.O. Doses de composto orgânico na produção e qualidade de sementes de brócolis. 2009. 50f. Dissertação (Mestrado em Agronomia/ Horticultura) - Faculdade de Ciências Agronômicas, Universidade Estadual Paulista, Botucatu, 2009. 
MAGRO, F.O.; CARDOSO, A.I.I.; FERNANDES, D.M. Acúmulo de nutrientes em sementes de brócolis em função de doses de composto orgânico. Cultivando o Saber, Cascavel, v.2, n.4, p.49-57, 2009.

MCPHARLIN, J.R.; JEFFERY, R.C.; PITMAN, D.H. Phosphorus requirements of winterplanted lettuce (Lactuca sativa L.) on a Karrakatta sand and the residual value of phosphate as determined by soil test. Australian Journal of Experimental Agriculture, Melbourne, v.36, n.7, p.897-903, 1996.

MCPHARLIN, J.R.; ROBERTSON, W.J. Response of spring-planted lettuce (Lactuca sativa L.) to freshly-applied and residual phosphorus and to phosphate fertilizer placement on a Karrakatta sand. Australian Journal of Experimental Agriculture, Melbourne, v.37, n.6, p.701-708, 1997.

MAGUIRE, J.D. Speeds of germination-aid selection and evaluation for seddling emergence and vigor. Crop Science, Madison, v.2, p.176-177, 1962.

MALAVOLTA, E. Elementos de nutrição mineral de plantas. São Paulo: Agronômica Ceres, 1980. 251p.

MALAVOLTA, E.; VITTI, G.C.; OLIVEIRA, S.A. Avaliação do estado nutricional das plantas, princípios e aplicações. 2.ed. Piracicaba: Potafós, 1997. 319p.

MARCHESINI, A.; ALLIEVI, L.; COMOTTI, E.; FERRARI, A. Long-term effects of quality compost treatment on soil. Plant and Soil, Dordrecht, v.106, p.253-261, 1988.

MARCOS FILHO, J. Fisiologia de sementes de plantas cultivadas. Piracicaba: Fealq, 2005. $495 \mathrm{p}$.

MARSCHNER, H. Mineral nutrition of higher plants. 2.ed. London: Academic Press, 1995. 889 p.

MOTA, J.H.; YURI, J.E.; RESENDE, G.M. de; OLIVEIRA, C.M.de; SOUZA, R.J. de; FREITAS, S.A.C.de; RODRIGUES JÚNIOR, J.C. Produção de alface americana em função da aplicação de doses e fontes de fósforo. Horticultura Brasileira, Brasília, v.21, n.4, p.620622, 2003.

NAGAI, H.; LISBÃO, R.S.; MELO, A.M.T.; TRANI, P.E.; PASSOS, F.A.; FORNASIER, J.B. Produção de sementes de hortaliças em pequenas áreas. Documentos IAC, Campinas, n.51, p.1-7, 1995 . 
NAGATA, R.T.; SANCHEZ, C.A.; COALE, F.J. Crisphead lettuce cultivar response to fertilizer phosphorus. Journal of the American Society for Horticultural Science, Alexandria, v.117, n.5, p.717-720, 1992.

NICOULAUD, B.A.L.; MEURER, E.J.; ANGHINONI, I. Rendimento e absorção de nutrientes por alface em função de calagem e adubação mineral e orgânica em solo "Areia Quartzosa Hidromórfica”. Horticultura Brasileira, Brasília, v.8, n.2, p.6-9, 1990.

OLIVEIRA, N.G.O.; De-POLLI, H.; ALMEIDA, D.L.; GUERRA, J.G.M. Plantio direto de alface adubada com cama de aviário sobre coberturas vivas de grama e amendoim forrageiro. Horticultura Brasileira, v.24, n.1, p.112-117, 2006.

PEREIRA, P.R.G.; FONTES, P.C.R. Nutrição mineral de hortaliças. In: FONTES, P.C.R. Olericultura: teoria e prática. Viçosa: Ed. UFV, 2005. 486p.

RAMOS JÚNIOR, E.U.; ZUCARELI, C.; PIRES, N.C.C.; NAKAGAWA, J.; FERNANDES, D.M. Adubação fosfatada e teores de nutrientes em sementes de feijão cv. IAC Carioca. In: CONGRESSO BRASILEIRO DE CIÊNCIA DO SOLO, 24., 2003, Ribeirão Preto. Anais... Ribeirão Preto, 2003. 1 CD-ROM.

REGHIN, M.Y.; OTTO, R.F.; ROCHA, A. Indução do florescimento e produção de sementes de alface com diferentes doses de ácido giberélico. Horticultura Brasileira, Brasília, v.18, n.3, p.171-175, 2000.

RICCI, M.S.F.; CASALI, V.W.D.; CARDOSO, A.A.; RUIZ, H.A. Teores de nutrientes em duas cultivares de alface adubadas com composto orgânico. Pesquisa Agropecuária Brasileira, Brasilía, v.30, n.8, p.1035-1039, 1995.

RODRIGUES, E.T.; CASALI, V.W.D. Rendimento e concentração de nutrientes em alface, em função das adubações orgânica e mineral. Horticultura Brasileira, Brasília, v.17, n.2, p.125-128, 1999.

RODRIGUES, E.T.; CASALI, V.W.D. Resposta da alface à adubação orgânica. II. Teores, conteúdos e utilização de macronutrientes. Revista Ceres, Viçosa, v.45, n.261, p.437-449, 1998.

ROUSOS, P. Effects of photoperiod and heat on lettuce growth and flowering time.

HortScience, Alexandria, v.236, n.3, p.155, 1988.

RYDER, E.J. Lettuce, endive and chicory. Wallingford: CABI Publishing, 1998. 208p. 
SÁ, M.E. Importância da adubação na qualidade de sementes. In: SÁ, M.E.; BUZZETI, S. (Eds.). Importância da adubação na qualidade dos produtos agrícolas. São Paulo: ÍCONE, 1994. p.65-98.

SANTOS, R.H.S.; CASALI, V.W.D.; CONDÉ, A.R.; MIRANDA, L.C.G. Qualidade de alface cultivada com composto orgânico. Horticultura Brasileira, Brasília, v.12, n.1, p.29-32, 1994.

SANTOS, R.H.S.; SILVA, F.; CASALI, V.W.D.; CONDE, A.R. Efeito residual da adubação com composto orgânico sobre o crescimento e produção de alface. Pesquisa Agropecuária Brasileira, Brasília, v.36, n.11, p.1395-1398, 2001.

SANCHEZ, C.A.; EL-HOUT, N.M. Response of diverse lettuce types to fertilizer phosphorus. HortScience, Alexandria, v.30, n.3, p.528-531, 1995.

SANCHEZ, C.A.; BURDINE, H.W.; GUZMAN, V.L.; HALL, C.B. Yield, quality, and leaf nutrient composition of crisphead lettuce as affected by N, P and K on Histosols. Proceedings of the Florida State Horticultural Society, Winter Haven, v.101, p.346-350, 1989.

SHINOHARA, S. (Ed.). Vegetable seed production technology of Japan elucidated with respective variety development histories, particulars. Tokyo, 1984. v.1, 432p.

SILVA, A.C.; GOULART JÚNIOR, S.A.R.; MENDONÇA, V.; TOSTA, M.S.; MACHADO, J.R.; BISCARO, G.A. Produção de alface Julia sob doses de superfosfato simples.

Horticultura Brasileira, Brasília, v.24, p.2099-2102, 2006.

SOFFER, H.; SMITH, O.E. Studies on lettuce seed quality: V. nutritional effects. Journal American Society for Horticultural Science, Alexandria, v.99, n.5, p.459-463, 1974a.

SOFFER, H.; SMITH, O.E. Studies on lettuce seed quality: III relationships between flowering pattern, seed yield, and seed quality. Journal of the American Society for Horticultural Science, Alexandria, v.99, n.2, p.114-117, 1974b.

SOUZA, J.L.; RESENDE, P. Manual de horticultura orgânica. Viçosa: Aprenda Fácil, 2003. 564p.

SOUZA, P.A.; NEGREIROS, M.Z.; MENEZES, J.B.; BEZERRA NETO, F.; SOUZA, G.L.F.M.; CARNEIRO, C.R; QUEIROGA, R.C.F. Características químicas de alface cultivada sob efeito residual da adubação com composto orgânico. Horticultura Brasileira, Brasília, v.23, n.3, p.754-757, 2005. 
VAN RAIJ, B. Fertilidade do solo e adubação. Piracicaba: Potafós, 1991. 343p.

VAN RAIJ, B.; CANTARELLA, H.; QUAGGIO, J.A.; FURLANI, A.M.C. Recomendações de adubação e calagem para o Estado de São Paulo. 2.ed. Campinas: Instituto Agronômico \& Fundação IAC, 1997. 285p.

VAN RAIJ, B.; ANDRADE, J.C.; CANTARELLA, H.; QUAGGIO, J.A. Análise química para avaliação da fertilidade de solos tropicais. Campinas: Instituto Agronômico, 2001. $285 \mathrm{p}$.

VIDIGAL, S.M.; RIBEIRO, A.C.; CASALI, V.W.D.; FONTES, L.E.F. Resposta da alface ao efeito residual da adubação orgânica: I. Ensaio de campo. Revista Ceres, Viçosa, v.42, n.239, p.80-88, 1995a.

VIDIGAL, S.M.; RIBEIRO, A.C.; CASALI, V.W.D.; FONTES, L.E.F.; Resposta da alface ao efeito residual da adubação orgânica: II. Ensaio em casa de vegetação. Revista Ceres, Viçosa, v.42, n.239, p.89-97, 1995 b.

VIDIGAL, S.M.; SEDIYAMA, M.A.N.; GARCIA, N.C.P.; MATOS, A.T. Produção de alface cultivada com diferentes compostos orgânicos e dejetos suínos. Horticultura Brasileira, Brasília, v.15, n.1, p.35-39, 1997.

VIEIRA, R.F. Influência de teores de P no solo sobre a composição química, qualidade fisiológica e desempenho no campo de sementes de feijão (Phaseolus vulgaris L.). Revista Ceres, Viçosa, v.33, n.186, p.173-188, 1986.

VIEIRA, R.D.; CARVALHO, N.M. Teste de vigor em sementes. Jaboticabal: FCAV/FUNEP, 1994. 164p.

VIEIRA, R.D.; SEDIYAMA, T.; CARVALHO, N.M.; THIEBAUT, J.T.L.; SILVA, R.F.; SEDIYAMA, C.S. Avaliação do efeito de doses de P e K na qualidade de sementes de soja. Revista Brasileira de Sementes, Brasília, n.1, p.83-89, 1987.

VIGGIANO, J. Produção de sementes de alface. In: CASTELLANE, P.D.; NICOLOSI, W.M.; HASEGAWA, M. (Eds.). Produção de sementes de hortaliças. Jaboticabal: FCAV/FUNEP, 1990. p.1-13.

VILLAS BÔAS, R.L.; PASSOS, J.C.; FERNANDES, D.M.; BÜLL, L.T.; CEZAR, V.R.; GOTO, R. Efeito de doses e tipos de compostos orgânicos na produção de alface em dois solos sob ambiente protegido. Horticultura Brasileira, Brasília, v.22, n.1, p.28-34, 2004.

YURI, J.E.; RESENDE, G.M.; RODRIGUES JUNIOR, J.C.; MOTA, J.H.; SOUZA, R.J. Efeito de composto orgânico sobre a produção e características comerciais de alface americana. Horticultura Brasileira, v.22, n.1, p.127-130, 2004. 
ZUCARELI, C. Adubação fosfatada, produção e desempenho em campo de sementes de feijoeiro cv. Carioca Precoce e IAC Carioca Tybatã. 2005. 183p. Tese (Doutorado em Agronomia/Horticultura) - Faculdade de Ciências Agronômicas, Universidade Estadual Paulista, Botucatu, 2005. 